\title{
Quaternary Stratigraphy of Southern Bavaria
}

\author{
Gerhard Doppler, Ernst Kroemer, Konrad Rögner, Johannes Wallner, Hermann Jerz, Walter Grottenthaler
}

Abstract:

\begin{abstract}
A review of current stratigraphical systems for the Quaternary sedimentary sequences of Southern Bavaria is given as it is used by the Geological Survey of the Bavarian Environment Agency. Different classification approaches for continental deposits of the Quaternary are highlighted with a special focus on the climate and terrace stratigraphy which are commonly used in Bavaria. A description of the associated informal units documents the current status of application and may lead to formal definitions. In Bavaria the traditional classification after PENCK \& BRÜCKNER (1901-1909) with its completions and refinements is still in use. New results concerning a more detailed structuring of the glacial epoch by subordinate cold and warm phases were integrated into this system. Terrace sequences are crucial for this classification of the Quaternary in Southern Bavaria whose chronological interpretation is the base of the so-called morphostratigraphy. Successions of terminal moraines which constitute glacial-glaciofluvial sequences with the associated terraces represent a second basis of stratigraphical division. Therefore, beside a detailed documentation of the terrace units also classifications of different terminal moraines are presented. Further stratigraphical systems are used in Bavaria and in adjacent areas which are based on different criteria or which lead to different chronological classifications. Even the described stratigraphical classifications are not used by all authors in the same way. The documentation of the current use may assist a coordination of different nomenclatures for the users benefit.
\end{abstract}

\section{[Quartärstratigraphie von Südbayern]}

Kurzfassung:

Eine Übersicht der aktuellen stratigraphischen Bezeichnungen für die quartäre Schichtenfolge Südbayerns wird gegeben, wie sie am Geologischen Dienst des Bayerischen Landesamts für Umwelt in Verwendung ist. Unterschiedliche stratigraphische Gliederungsansätze für kontinentale Quartärablagerungen werden vorgestellt und die klimatostratigraphische Einteilung sowie die Terrassenstratigraphie als in Bayern meistverwendete Varianten näher ausgeführt. Die Beschreibung der zugehörigen, bisher informellen Einheiten bezweckt eine Dokumentation des jeweiligen Stands der Verwendung und kann womöglich formelle Definitionen vorbereiten. Die klimatostratigraphischen Einheiten sollen den gesamten Zeitraum des Quartärs lückenlos abdecken und vertreten derzeit überregionale, formelle Stufenbezeichnungen. In Bayern wird weiterhin die klassische Gliederung nach PENCK \& BRÜCKNER (1901-1909) mit ihren Erweiterungen verwendet. Neue Erkenntnisse über eine stärkere Gliederung des Eiszeitalters durch untergeordnete Kalt- und Warmphasen werden in dieses System integriert. Für diese Gliederung des Quartärs in Südbayern ausschlaggebend sind zum Einen die Terrassentreppen, deren zeitliche Interpretation eine Grundlage der sogenannten Morphostratigraphie bildet. Die zweite Grundlage bilden Endmoränengirlanden, die mit den davon ausgehenden Terrassen glazial-glazifluviale Sequenzen (,Glaziale Serien') bilden. Neben der ausführlichen Dokumentation der Terrassen-Einheiten, werden deshalb auch verschiedene Endmoränen-Gliederungen vorgestellt. Weitere Nomenklaturen, die auf anderen Kriterien beruhen oder zu anderen chronologischen Einstufungen gelangen, sind für Bayern oder in den angrenzenden Ländern in Gebrauch. Auch die beschriebenen stratigraphischen Gliederungen werden nicht von allen Bearbeitern in gleicher Weise verwendet. Die Dokumentation der derzeitigen Verwendung soll eine Abstimmung dieser Nomenklaturen im Interesse der Nutzer fördern.

Keywords:

Quaternary stratigraphy, climate stratigraphy, terrace stratigraphy, moraine stratigraphy, Southern Bavaria, Germany, Alpine Foreland

Addresses of authors: G. Doppler, Bayerisches Landesamt für Umwelt, Geologischer Dienst, Dienstort Lazarettstraße 67, D-80636 München. E-Mail: gerhard.doppler@lfu.bayern.de; W. Grottenthaler, Brunnenstraße 20, D-85598-Baldham. E-Mail: grottenthaler-baldham@ t-online.de; H. Jerz, Eichleite 7, D-82031 Grünwald. E-Mail: hjerz@yahoo.de; E. Kroemer and J. Wallner, Bayerisches Landesamt für Umwelt, Geologischer Dienst, Dienststelle Hof, Hans-Högn-Str. 12, D-95030 Hof/Saale. E-Mail: ernst.kroemer@ lfu.bayern.de, johannes.wallner@lfu.bayern.de; K. Rögner, Ludwig-Maximilians-Universität München, Department für Geographie, Luisenstraße 37, D-80333 München. E-Mail: k.roegner@geographie.uni-muenchen.de

\section{Introduction}

More than 100 years of investigation of Quaternary deposits in the northern Alpine region led to numerous proposals for classification of the sediments accumulated during the Pleistocene epoch (FIEBIG et al., in press). Hence, a hardly manageable number of different nomenclatures evolved, often accompanied by different use of synonymic terms. Against this background the 'Arbeitsgemeinschaft Alpenvorlandquartär' (AGAQ; Working Group on the Quaternary of the Alpine Foreland) aims at documenting and defining stratigraphic systems and terms used in the northern Alpine region in order to make them better comparable. This paper intends to present a stratigraphical standard classification for the Bav- arian Alpine Foreland as it is currently used in the Geological Survey (Bavarian Environment Agency). References to different applied glossaries shall give assistance for understanding the diversity of nomenclatures in the relevant literature. For a better understanding of the primary literature we consequently use the original german terms in this paper.

The application of the 'International Stratigraphic Guide' (SALVAdOR 1994) and resulting suggestions (SteININGer \& Piller 1999) for continental quaternary deposits raises some trouble. They show very small-scaled changes in facies and also pronounced hiatuses. Thus there is a need for high chronological resolution, but at the same time there is a lack of appropriate dating methods for the older parts of the Quaternary (PREUSSER et al. 2008). 


\section{Table of content}

1 Introduction

2 Stratigraphic systems of the Quaternary

2.1 Chronostratigraphy and comparable classification systems

2.2 Biostratigraphy

2.3 Lithostratigraphy and comparable classification systems

3 Regional Quaternary stratigraphy of Southern Bavaria

3.1 Climate stratigraphy for Southern Bavaria

3.1.1 Biber ('Biberian')

3.1.2 Donau ('Danubian')

3.1.3 Günz ('Guenzian')

3.1.4 Günz/Mindel ('Guenz/Mindelian')

3.1.5 Mindel ('Mindelian' sensu lato)

3.1.6 Mindel/Riß ('Mindel/Rissian')

3.1.7 Riß ('Rissian')

3.1.8 Riß/Würm ('Riss/Wuermian')

3.1.9 Würm ('Wuermian')

3.1.10 Holocene

3.2 Terrace stratigraphy for Southern Bavaria

3.2.1 Ältester Deckenschotter

('Oldest Cover Gravel')

3.2.2 Ältester Periglazialschotter

('Oldest Perglacial Gravel')

3.2.3 Höherer Älterer Deckenschotter

('Higher Older Cover Gravel')

3.2.4 Tieferer Älterer Deckenschotter

('Lower Older Cover Gravel')

3.2.5 Jüngerer Deckenschotter

('Younger Cover Gravel')

3.2.6 Hochterrasse ('Higher Terrace')

3.2.7 Übergangsterrasse ('Transitional Terrace')

3.2.8 Niederterrasse ('Lower Terrace')

3.2.9 Spätglazialterrasse ('Late Glacial Terrace')

3.2.10 Postglazialterrasse ('Post Glacial Terrace') 3.2.10.1 Jüngere Postglazialterrasse

('Younger Post Glacial Terrace')

3.3 Moraine stratigraphy for Southern Bavaria

3.3.1 Geomorphological moraine classification

3.3.2 Classification by terminal moraine stages

4 Discussion and perspectives

5 References

\section{Stratigraphical systems}

MurPhy \& SALVAdor (1999) distinguish five essential categories of stratigraphic classifications dependent on the criteria applied for the discrimination of each unit:

(i) lithostratigraphy,

(ii) stratigraphy by unconformity bounded units,

(iii) biostratigraphy,

(iv) magnetostratigraphy,

(v) chronostratigraphy.

All those different kinds of stratigraphical classification and further comparables - can be applied in different ways to organise the Quaternary.
The marine oxygen isotope stages (MIS) and the magnetostratigraphy serve as an international reference scale for a chronological classification of the Quaternary (Crowhurst 2002, OGg \& SMITH 2004). The contribution of magnetostratigraphical investigations to the stratigraphical classification of Quaternary deposits in Bavaria is limited due to generally short and fragmentary sediment sequences (STRATTNER \& Rolf 1995; HAMBACH et al. 2008).

The MIS provide a detailed classification of the marine Quaternary, reflecting changes in sea water temperatures and global ice volume (Crowhurst 2002). Currently the MIS display the most common international reference scale for the classification of Quaternary deposits. However, correlation with continental sedimentary units and climatic phases is not straightforward and difficult without numeric ages of the continental sequences.

\subsection{Chronostratigraphy and comparable stratigraphic systems}

Validating the Quaternary as the youngest period/system of the Earth's history and the expansion of its lower boundary to $2.58 \mathrm{Ma}$ by the International Union of Geological Sciences (IUGS) (GIBBARD et al. 2009) paid regard to a long existing usage in many regions with continental Quaternary deposits and also in Bavaria. The subdivision of the Pleistocene in subseries/subepochs (Lower/Early, Middle, Upper/Late Pleistocene) is still in progress (LiTT et al. in prep.). Like the base of the Quaternary (base of Gelasian) the boundary between Lower/Early and Middle Pleistocene is linked to a polarity change of the Earth's magnetic field, the transition from Matuyama (reversed) to Brunhes epoch (normal). This demarcation indeed is traceable throughout the world. However, it is disconnected from the commonly applied main climate stratigraphical classification because a correlation of climate and polarity changes is not expected.

Internationally established Quaternary stages only exist for marine deposits. In continental environments a chronostratigraphical classification is often replaced by a regional climate stratigraphy differentiating cold and warm phases. Even without a formal definition this phases often are used like chronostratigraphical stage terms (e. g. 'Saalian', 'Eemian').

\subsection{Biostratigraphy}

Biostratigraphically significant locations of the Quaternary in Bavaria are summarised in Table 1. The stratigraphical classification of the warm-temperate phases of the Pleistocene and the Holocene is essentially based on palynological analyses which are summarised in Drescher-SCHNEIDER et al. (2001).

The current mammalian stratigraphy for the Pleistocene in Germany is largely based on small mammal remains (Koenigswald \& HeInRICH 2007). They are better suitable because of their faster evolutionary development (Koenigswald 2002). But like the remains of large mammals, localities enriched in small mammals are very rare. This holds particularly true for deposits older than Upper Pleistocene. 


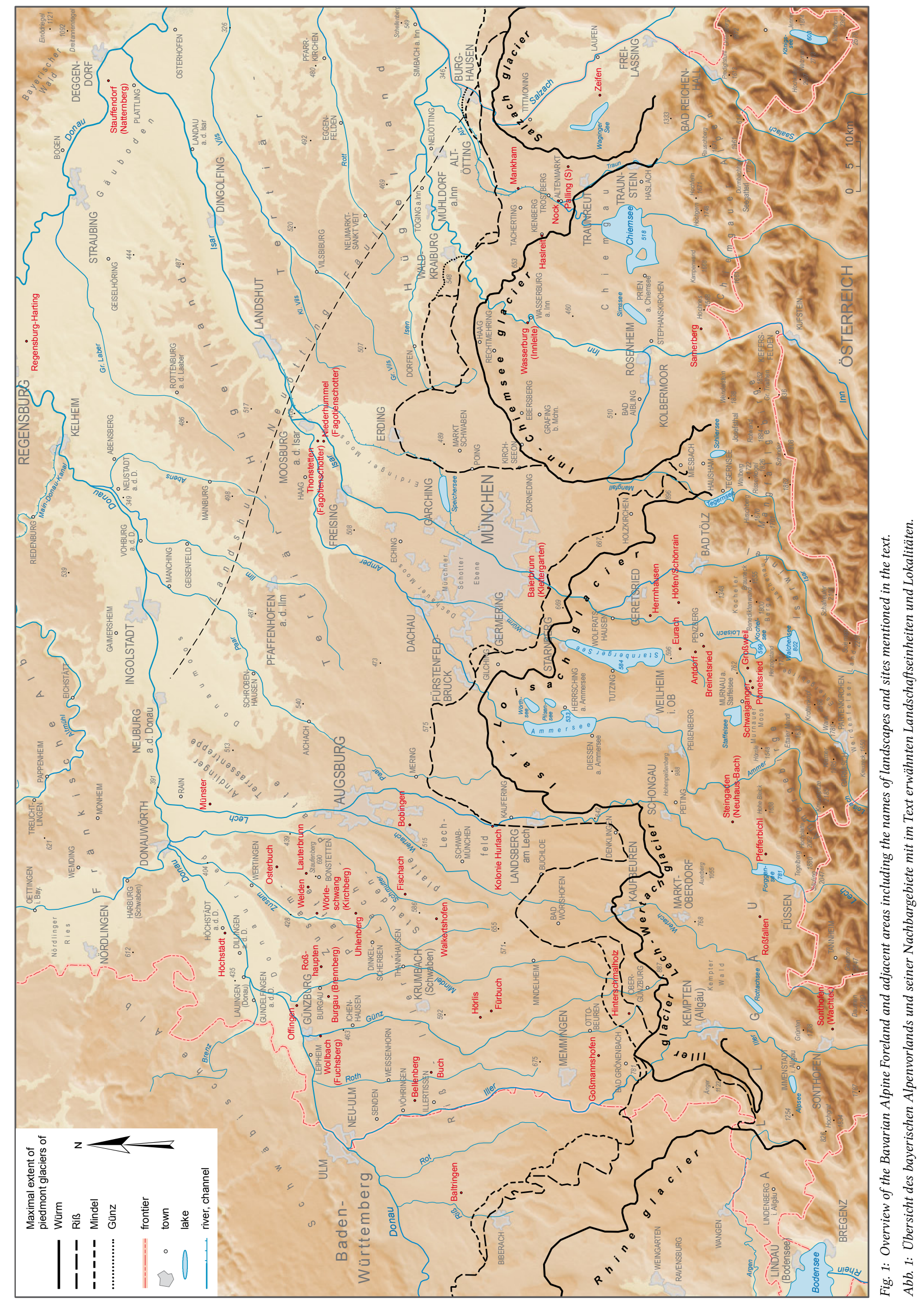


Tab. 1: Biostratigraphically important localities of the Pleistocene in Southern Bavaria. Codes for geological units composed of stratigraphy and facies/lithology; the code of the unit containing the fauna or flora in bold characters; Stratigraphic codes: B =Biber; D = Donau; $M=M i n d e l ; M / R=M i n d e l / R i \beta ;$ OSM = Upper Freshwater Molasse (Obere Süßwassermolasse); qh = Holocene; $R=$ Ri $\beta ;$ Rj = Jungri $\beta ; R / W=$ Ri $\beta /$ Würm; USM = Lower Freshwater Molasse ('Untere Süßwassermolasse'); $W=$ Würm; Wf = early Würm ('Frühwürm'). Facial /lithologic codes: , $f=$ fluvial; ,,fl = solifluction loam; ,g = morainic; , $G=$ gravel; ,H = peat $;, H p=$ compressed peat ('Schieferkohle'); ,l = lacustrine; , K = lime ('sinter', 'chalk'); ,Kq = solid sinter ('Kalktuff'); ,Lo = loess; ,Lol = loess loam; ,M = marl $;(M)=\operatorname{clod}(s)$ of marl $;, p=$ periglacial, $\uparrow=$ succession .

Tab. 1: Biostratigraphisch bedeutsame Lokalitäten im Pleistozän des Bayerischen Alpenvorlands.

Tab. 1a: Palynological localities.

Tab. 1a: Fundorte mit Pollenfloren.

\begin{tabular}{|c|c|c|c|c|c|c|}
\hline TK25 & Locality & Coordinates & Bedding & $\begin{array}{l}\text { Ecology/ } \\
\text { interpretation }\end{array}$ & Classification & Reference \\
\hline 7726 & Bellenberg & $\begin{array}{l}3582200 \\
5347100 \\
\end{array}$ & $\begin{array}{l}\text {,Lo-, ,fl with ,H / W,G,p } \\
\text { / OSM }\end{array}$ & glacial & Würm pleniglacial & PESCHKE [1982, unpubl. report] \\
\hline 8027 & Goßmannshofen & $\begin{array}{l}3592700 \\
5310400 \\
\end{array}$ & ,fl / ,H / R,G & glacial & Würm & FrEnZEL [1974, unpubl. report] \\
\hline 8427 & $\begin{array}{l}\text { Sonthofen [Kgr. } \\
\text { Wachter] }\end{array}$ & $\begin{array}{l}3599850 \\
5263500 \\
\end{array}$ & $\begin{array}{l}\text { W,g / W,G / , Hp in W,I } \\
/ R, G+R,, g\end{array}$ & interstadial & Early Würm & PeschKe [1983a] \\
\hline 8233 & Antdorf & $\begin{array}{l}\approx 4449850 \\
\approx 5291650\end{array}$ & $\begin{array}{l}\text { W,,g / W,G / W,I with } \\
\text {,Hp }\end{array}$ & interstadial & Early Würm & PESchKe [1983a] \\
\hline 8333 & Pömetsried & $\begin{array}{l}4442650 \\
5280150 \\
\end{array}$ & W,G / , Hp / W,,I & interstadial & Early Würm & $\begin{array}{l}\text { REICH [1953]; } \\
\text { PESCHKE [1983a] } \\
\end{array}$ \\
\hline 7939 & $\begin{array}{l}\text { Wasserburg, } \\
\text { verschiedene Fundorte }\end{array}$ & $\begin{array}{l}\approx 4516200 \\
\approx 5325500\end{array}$ & W,G with , Hp & interstadial & Early Würm & FRENZEL \& JoChIMSEN [1972] \\
\hline 8234 & Breinetsried & $\begin{array}{l}4451200 \\
5289900 \\
\end{array}$ & W,G with , Hp & interstadial & Early Würm: Moershoofd? & Peschke [1983a] \\
\hline 8234 & Höfen/Schönrain & $\begin{array}{l}4459810 \\
5295030 \\
\end{array}$ & W,G with , Hp & interstadial & Early Würm & Peschke [1983a] \\
\hline 8333 & Schwaiganger & $\begin{array}{l}\approx 4444000 \\
\approx 5280600\end{array}$ & W, G with 2 , Hp & interstadial & $\begin{array}{l}\text { Early Würm: Odderade? } \\
\text { Brørup? }\end{array}$ & Peschke [1983a] \\
\hline 8329 & Roßfallen & $\begin{array}{l}\approx 4396500 \\
\approx 5278650\end{array}$ & $W_{,,} \mathrm{g} /, \mathrm{Hp}+\mathrm{W}_{,, \mathrm{I}} / \mathrm{USM}$ & $\begin{array}{l}\text { interstadial } \\
\text { terminal } \\
\text { interglacial } \uparrow \\
\end{array}$ & $\begin{array}{l}\text { Early Würm } \\
\text { end of Riß/Würm }\end{array}$ & $\begin{array}{l}\text { STRITZKE [1996, unpubl. report] } \\
\text { correlated to Pfefferbichl }\end{array}$ \\
\hline 8331 & Steingaden & $\begin{array}{l}4415600 \\
5284150\end{array}$ & W,,g / Wf-R/W,,I & $\begin{array}{l}\text { interstadial } \\
\text { terminal } \\
\text { interglacial } \uparrow \\
\end{array}$ & $\begin{array}{l}\text { Early Würm } \\
\text { end of Riß/Würm }\end{array}$ & HöFLE \& MülLeR [1983] \\
\hline 8330 & Pfefferbichl & $\begin{array}{l}4409150 \\
5277460\end{array}$ & W,I / , Hp / R,,I & $\begin{array}{l}\text { glacial } \\
\text { interglacial } \uparrow\end{array}$ & $\begin{array}{l}\text { Würm } \\
\text { Riß/Würm }\end{array}$ & $\begin{array}{l}\text { ReICH [1953]; } \\
\text { FRENZEL [1976] } \\
\end{array}$ \\
\hline 8333 & Großweil & $\begin{array}{l}\approx 4446600 \\
\approx 5281100\end{array}$ & $\begin{array}{l}\text { W,G / Wf-R/W, I with } \\
\text {,Hp / R,G+S }\end{array}$ & $\begin{array}{l}\text { interstadial } \\
\text { interglacial } \uparrow \\
\end{array}$ & $\begin{array}{l}\text { Early Würm } \\
\text { Riß/Würm } \uparrow \\
\end{array}$ & $\begin{array}{l}\text { REICH [1953]; } \\
\text { PESCHKE [1976] } \\
\end{array}$ \\
\hline 8239 & Samerberg 1 & $\begin{array}{l}4515150 \\
5290350\end{array}$ & $\begin{array}{l}\text { W,g / Wf-R/W,I/ R, g } \\
/ ? \text { ? }, \mathrm{I} / \mathrm{M}_{,, \mathrm{g}}\end{array}$ & \begin{tabular}{|l} 
interstadial \\
interglacial $\uparrow$
\end{tabular} & $\begin{array}{l}\text { Early Würm } \\
\text { Eem [= Riß/Würm] } \uparrow\end{array}$ & GRÜGER [1979] \\
\hline 8134 & Herrnhausen & $\begin{array}{l}\approx 4457200 \\
\approx 5300750\end{array}$ & $\begin{array}{l}\text { W,,g / W,G / ,Hp / Rj,,l } \\
/ \text { R,,g }\end{array}$ & $\begin{array}{l}\text { interglacial } \\
\text { glacial } \uparrow\end{array}$ & $\begin{array}{l}\text { Riß/Würm } \\
\operatorname{Riß} \uparrow\end{array}$ & PESCHKe $[1983 \mathrm{~b}]$ \\
\hline 8042 & Zeifen & $\begin{array}{l}4562100 \\
5310910 \\
\end{array}$ & W,G / Rj-R/W,K,I & $\begin{array}{l}\text { interglacial } \\
\text { glacial } \uparrow\end{array}$ & $\begin{array}{l}\mathrm{Riß} / \text { Würm } \\
\operatorname{Riß} \uparrow \\
\end{array}$ & Jung et al. [1972] \\
\hline 8234 & Eurach & $\begin{array}{l}\approx 4450500 \\
\approx 5294750\end{array}$ & W,G / Rj-R/W,K,I & $\begin{array}{l}\text { interglacial } \\
\text { glacial } \uparrow \\
\end{array}$ & $\begin{array}{l}\mathrm{Riß} / \text { Würm } \\
\operatorname{Riß} \uparrow \\
\end{array}$ & $\begin{array}{l}\text { BEUg [1979]; } \\
\text { Jung [1979]: macro remains }\end{array}$ \\
\hline 7039 & $\begin{array}{l}\text { Regensburg-Harting } \\
{[\mathrm{BMW}]}\end{array}$ & $\begin{array}{l}\approx 4512500 \\
\approx 5426500\end{array}$ & ?Ra,G / , H / ?,G & interglacial & Middle Pleistocene? & Grosse-Beckmann [1993] \\
\hline 8239 & Samerberg 2 & $\begin{array}{l}4514800 \\
5290760 \\
\end{array}$ & $\begin{array}{l}W_{,}, \mathrm{g} / \mathrm{Wf}-\mathrm{R} / \mathrm{W}_{,}, \mathrm{I} / \mathrm{R}, \mathrm{g} \\
/ \mathrm{R}-\mathrm{M} / \mathrm{R}, \mathrm{K}-\mathrm{M}, \mathrm{I} / \mathrm{M}, \mathrm{g}\end{array}$ & $\begin{array}{l}\text { interglacial - } \\
\text { interstadial }\end{array}$ & $\begin{array}{l}\text { Holstein II [= ??] } \\
\text { Holstein [= Mindel/Riß] }\end{array}$ & GRÜGER [1983] \\
\hline 7629 & Uhlenberg & $\begin{array}{l}4397200 \\
5360100\end{array}$ & $\begin{array}{l}\text {,Lol-, ,fl / ,Hp / ,M,f } \\
\text { / D,G }\end{array}$ & interglacial & $\begin{array}{l}<\text { Tegelen, > Cromer } \\
\text { Bavel? }\end{array}$ & \begin{tabular}{|l} 
SCHedler [1979]; \\
BLudAu [1995]
\end{tabular} \\
\hline
\end{tabular}

Tab. 1b: Malacological or mammal localities.

Tab. 1b: Fundorte mit Mollusken- oder Kleinsäugerfaunen.

\begin{tabular}{|c|c|c|c|c|c|c|}
\hline TK25 & Locality & Coordinates & Bedding & Ecology/interpretation & Classification & Reference \\
\hline \multicolumn{7}{|c|}{ Molluscs: } \\
\hline 8427 & $\begin{array}{l}\text { Sonthofen [gravel pit } \\
\text { "Wachter"] }\end{array}$ & $\begin{array}{l}3599850 \\
5263500 \\
\end{array}$ & $\begin{array}{l}\text { W,g / W,G / , Hp in } \\
W_{,, I} / \mathrm{R}, \mathrm{G}+\mathrm{R}, \mathrm{g}\end{array}$ & interstadial & Early Würm & Dehm in Ebel [1983] \\
\hline 7831 & Kolonie Hurlach & $\begin{array}{l}4414730 \\
5332570\end{array}$ & $q h, G / \mathbf{R} / \mathbf{W}, \mathbf{K q}$ & interglacial & Riß/Würm & Kovanda [1989] \\
\hline 7329 & Höchstädt & $\begin{array}{l}4393200 \\
5386500\end{array}$ &, $\mathrm{Lo} /[, \mathrm{M}]$ in $\mathrm{R}, \mathrm{G}$ & \begin{tabular}{|l} 
interglacial or \\
interstadial [warm]
\end{tabular} & ?Inner-Riß & Puissegur in Leger [1988] \\
\hline 7331 & Münster & $\begin{array}{l}4419200 \\
5389500\end{array}$ & {$[, M]$ in $R, G$} & interglacial & Pleistocene & $\begin{array}{l}\text { TILLMAnNs et al. [1982]; RÄHLE } \\
\text { [1994, unpubl. report] }\end{array}$ \\
\hline 7731 & Bobingen & $\begin{array}{l}4415000 \\
5349250\end{array}$ & $\begin{array}{l}\text {,Lo /,,fl / }[, M] \text { in } \\
R, G\end{array}$ & interglacial & Older than Eem & RÄHLE [1994, unpubl. report] \\
\hline
\end{tabular}




\begin{tabular}{|c|c|c|c|c|c|c|}
\hline 8234 & Eurach & $\begin{array}{l}\approx 4450650 \\
\approx 5294760\end{array}$ & W,G / Rj-R/W,K,I & interglacial & $\begin{array}{l}\text { Riß/Würm or } \\
\text { Pre-Mindel ? } \\
\end{array}$ & $\begin{array}{l}\text { DeHM [1979]; OHMERT [1979] } \\
\text { Ostracoden; KovAnda [2006] }\end{array}$ \\
\hline 7537 & $\begin{array}{l}\text { Thonstetten } \\
\text { [Fagotienschotter] }\end{array}$ & $\begin{array}{l}4492400 \\
5367800\end{array}$ & $\begin{array}{l}\text {,Lo / ,fl /,S in ?R,G } \\
\text { or ?G,G }\end{array}$ & $\begin{array}{l}\text { interglacial, river + } \\
\text { floodplain }\end{array}$ & Older than Mindel? & $\begin{array}{l}\text { BRUNNACKER \& BRUNNACKER } \\
\text { [1962]; KovANDA [2006] }\end{array}$ \\
\hline 7537 & $\begin{array}{l}\text { Niederhummel } \\
\text { [Fagotienschotter] }\end{array}$ & $\begin{array}{l}4492350 \\
5366600 \\
\end{array}$ & $\begin{array}{l}\text {,Lo / ,fl / ,M,f / } \\
\text { ?R,G or ?G,G }\end{array}$ & $\begin{array}{l}\text { interglacial, river + } \\
\text { floodplain }\end{array}$ & Older than Mindel? & $\begin{array}{l}\text { BRUNNACKER \& BRUNNACKER } \\
\text { [1962]; Kovanda [2006] }\end{array}$ \\
\hline 7629 & Uhlenberg & $\begin{array}{l}4397200 \\
5360100 \\
\end{array}$ & $\begin{array}{l}\text {,Lol- „,fl / ,Hp / , M,f } \\
/ \mathrm{D}, \mathrm{G}\end{array}$ & $\begin{array}{l}\text { interglacial; } \\
\text { floodplain }\end{array}$ & $\begin{array}{l}\text { Tiglian?, possibly } \\
\text { Waal? } \approx \text { Buch? }\end{array}$ & RÄHLE [1995] \\
\hline 7530 & Lauterbrunn & $\begin{array}{l}4405250 \\
5370100 \\
\end{array}$ & ,Lol+,,fl / D,G & $\begin{array}{l}\text { interglacial; } \\
\text { floodplain }\end{array}$ & $\begin{array}{l}\text { Tiglian?, possibly } \\
\text { Waal? } \approx \text { Buch? }\end{array}$ & RÄHLE [1995] \\
\hline 7828 & Fürbuch & $\begin{array}{l}3600810 \\
5332390 \\
\end{array}$ & $\begin{array}{l}\text { D,G / „, f [reloc. } \\
\text { OSM] }\end{array}$ & $? ? ?$ & Pleistocene & MüNZING [1974] \\
\hline 7828 & Hörlis & $\begin{array}{l}3599450 \\
5334550\end{array}$ & $D, G /[, M] / B, G, p$ & $\begin{array}{l}\text { interglacial, } \\
\text { humid deciduous forest } \\
+ \text { river }\end{array}$ & before Riß/Würm & MünZING [1974] \\
\hline 7727 & Buch & $\begin{array}{l}\text { ?3588000 } \\
\text { ?5344000 }\end{array}$ & $\mathrm{D}, \mathrm{G} / \mathrm{M} / \mathrm{B}, \mathrm{G}, \mathrm{p}$ & $\begin{array}{l}\text { interglacial, } \\
\text { humid deciduous forest, } \\
\text { floodplain }\end{array}$ & Early Pleistocene & $\begin{array}{l}\text { Schröder \& Dehm [1951] } \\
\text { Münzing \& OHMERT [1974] }\end{array}$ \\
\hline 7528 & Brennberg/Burgau & $\begin{array}{l}3602450 \\
5365280 \\
\end{array}$ & $\begin{array}{l}{[, M] \text { in } B, G, p} \\
\text { [Urdonau] }\end{array}$ & interglacial & Pleistocene & $\begin{array}{l}\text { MÜNZING in LöSCHER et al. } \\
{[1978]}\end{array}$ \\
\hline 7529 & Kirchberg/Wörleschwang & $\begin{array}{l}4397200 \\
5367950 \\
\end{array}$ & $\begin{array}{l}{[, M] \text { in } B, G, p} \\
\text { [Urdonau] } \\
\end{array}$ & interglacial & Pleistocene & $\begin{array}{l}\text { MÜNZING in LöSCHER et al. } \\
{[1978]}\end{array}$ \\
\hline 7529 & Fuchsberg/Wollbach & $\begin{array}{l}3594430 \\
5366580\end{array}$ & $\begin{array}{l}\text { D,G [Mischfazies }] / \\
{[, M] / B, G, p}\end{array}$ & $\begin{array}{l}\text { interglacial, } \\
\text { deciduous forest - } \\
\text { alluvial forest } \\
\end{array}$ & Pleistocene & MÜnZIng \& AKTAS [1984] \\
\hline 7530 & Welden & $\begin{array}{l}4402500 \\
5369720 \\
\end{array}$ & $\begin{array}{l}\text { D,G [Mischfazies] / } \\
{[, M] / B, G, p}\end{array}$ & interstadial & Pleistocene & MÜNZING \& AKTAS [1984] \\
\hline 7430 & Osterbuch & $\begin{array}{l}4406570 \\
5376040\end{array}$ & {$[, M]$ in $D, G$} & $\begin{array}{l}\text { interglacial, } \\
\text { deciduous forest - } \\
\text { alluvial forest }\end{array}$ & $\approx$ Buch & MÜNZING \& AKTAS [1984] \\
\hline 7729 & Walkertshofen & $\begin{array}{l}? 4396100 \\
? 5343850\end{array}$ & B,G with $[, M]$ & $\begin{array}{l}\text { interstadial or early } \\
\text { interglacial? }\end{array}$ & $\approx$ Fischach / Buch & EBERL [1930: 309] \\
\hline 7730 & Fischach & $\begin{array}{l}? 4401060 \\
? 5350150\end{array}$ & B, G with $[, M]$ & $\begin{array}{l}\text { interstadial or early } \\
\text { interglacial? floodplain }\end{array}$ & $\begin{array}{l}\text { „Altpleistozän“; } \\
\text { ₹ Buch }\end{array}$ & SCHRÖDER \& Dehm [1951] \\
\hline \multicolumn{7}{|c|}{ Small mammals: } \\
\hline 7629 & Uhlenberg & $\begin{array}{l}4397240 \\
5360150\end{array}$ & $\begin{array}{l}\text {,Lol-, ,fl / , Hp / ,M,f } \\
/ \text { / D,G }\end{array}$ & --- & $\begin{array}{l}\text { Villanyium, MN } 17 \\
\text { [corr. youngest } \\
\text { Tiglian] } \\
\end{array}$ & ELLWANGER et al. [1994] \\
\hline
\end{tabular}

Mollusc faunae provide the opportunity for correlations with climate stratigraphy of the Nordic glaciations (Dенм 1979, MÜNZING \& AKTAS 1987, RäHLE 1995, KovandA 2006). However, a distinct classification system with typical communities or type fossils (LozEK 1964) is not established.

For other zoological taxa no biostratigraphical classification systems are established for the continental Quaternary so far. However, a relative stratigraphical correlation is partly feasible when accompanied by additional investigations (e. g. isotopic analyses on ostracodes by Grafenstein et al. 1992).

\subsection{Lithostratigraphy and comparable classification systems}

In Bavaria the traditional classification systems (with some further adjustments) are still applied. According to the original classification of PeNCK \& BRÜCKNER (1901-1909) primarily morphological aspects were in the focus which later led to the term 'morphostratigraphy'. However, the base forming concept of the 'Glaziale Serie' and 'Glazialer Komplex' (glacial-glaciofluvial sequences of one glacial phase respectively of one ice advance) introduced by PENCK \& BRÜCKNER (1901-09: 13f) also contains litho-facies aspects.

\section{Lithostratigraphy.}

At present a lithostratigraphical system for the deposits of the South German Quaternary is only applied in Baden-
Württemberg in the area of the Pleistocene Rhine glacier. Its framework is primarily based on the observed succession of basin fills (ELLWANGER et al. 2003).

Morphostratigraphy.

The classification into different 'Glaziale Serien' is the base of the climate stratigraphical classification (glacials and interglacials) and as well of a subdivision into 'morphostratigraphic' units with regard to moraine and meltwater deposits (terraces).

The terrace stratigraphy primarily uses the relative altitudinal position of meltwater deposits and - in second order - the composition of the gravel deposits and their covering strata. This led to terms like 'Niederterrasse' (Lower Terrace), 'Hochterrasse' (Higher Terrace) or 'Deckenschotter' (Cover Gravel). In addition distinct local terms are used in different valley systems (e. g. 'Altstadtstufe' of the river Isar at Munich).

Moraine stratigraphy uses different terminal moraine stages in connection with their respective gravel plains. Differences in relief and depth of weathering play an important role for categorisation. A supra-regional classification is only used for the terminal stages of 'Hochwürm' (Wuerm pleniglacial).

\section{Pedostratigraphy.}

A stratigraphic classification similar to the lithostratigraphic one was based on palaeosols in younger loess sequences by Semmel (1968), Bibus (1974) and Zollinger (1991). It was established north of the Alpine Foreland where high 
Tab. 2: Pedostratigraphy of the younger Pleistocene of Southern Germany; chronology and classification of the palaeosols older than Riß/Würm (= Eemian) are still uncertain. Bimstuff = pumice tuff; Bt = argic horizon; $($ Nass-)Boden $=($ initial hydromorphic $)$ soil; Humuszone = humous horizon; Taschenboden $=$ involution layer (soil relics in hollow moulds); Tundragley = cryic gleysol.

Tab. 2: Pedostratigraphische Einheiten des jüngeren Pleistozäns zur Verwendung im Alpenvorland.

\begin{tabular}{|c|c|c|c|}
\hline \multicolumn{2}{|c|}{ Climate stratigraphy } & Loess soils & Gravel soils \\
\hline & & & \\
\hline Holocene & & recent soil & recent soil \\
\hline \multirow[t]{3}{*}{ Würm } & $\begin{array}{l}\text { Oberes Würm [Upper / } \\
\text { Late Würmian] }\end{array}$ & $\begin{array}{l}\text { [Laacher Bimstuff] } \\
\text { Erbenheimer [Nass-]Boden E4 } \\
\text { [Eltviller Tuff] } \\
\text { Erbenheimer [Nass-]Boden E3 } \\
\text { Erbenheimer [Nass-]Boden E2 } \\
\text { Erbenheimer [Nass-]Boden E1 } \\
\text { [Rambacher Tuff] }\end{array}$ & \\
\hline & $\begin{array}{l}\text { Mittleres Würm } \\
\text { [Middle Würmian] }\end{array}$ & $\begin{array}{l}\text { Lohner Boden / } \\
\text { Böckinger Boden } \\
\text { Tundragley } \\
\text { Gräselberger Boden }\end{array}$ & \\
\hline & $\begin{array}{l}\text { Unteres Würm } \\
\text { [Lower / Early Würmian] }\end{array}$ & $\begin{array}{l}\text { Niedereschbacher Zone } \\
\text { Obere Moosbacher Humuszone } \\
\text { Mittlere Moosbacher Humuszone } \\
\text { Untere Moosbacher Humuszone }\end{array}$ & \\
\hline Riß /Würm & [= Eemian] & $1^{\text {st }}$ fossile Bt [Eem-Boden] & Rosnaer Boden \\
\hline \multirow[t]{4}{*}{ Riß } & Jungriß & $\begin{array}{l}\text { Bruchköbeler [Nass-]Boden B6 } \\
\text { Bruchköbeler [Nass-]Boden B5 } \\
\text { Bruchköbeler [Nass-]Boden B4 } \\
\text { Bruchköbeler [Nass-]Boden B3 } \\
\text { Bruchköbeler [Nass-]Boden B2 } \\
\text { Bruchköbeler [Nass-]Boden B1 } \\
\text { Ostheimer Zone } \\
\text { Obere Weilbacher Humuszone }\end{array}$ & \\
\hline & ?Mittel/Jungriß & $2^{\text {nd }}$ fossile Bt & Baltringer Boden \\
\hline & Mittelriß & $\begin{array}{l}\text { Tundragley } 2 \\
\text { Tundragley } 1 \\
\text { Allschwiler Zone } \\
\text { [Reinheimer Tuff] } \\
\text { Heilbronner [Reinheimer] Humuszone }\end{array}$ & \\
\hline & ?Alt/Mittelriß & $3^{\text {rd }}$ fossile Bt [Biesigheim] & 'Taschenboden' v. Bittelschieß \\
\hline Mindel /Riß & $\begin{array}{l}\text { Altriß } \\
\text { [= Holsteinian] }\end{array}$ & $4^{\text {th }}$ fossile Bt & Neufraer Boden \\
\hline Mindel & & & \\
\hline
\end{tabular}

resolution sequences are available. But even older terms with stratigraphic content are in use (BRUNNACKER 1953, 1982; FINK 1956). A recent stratigraphical differentiation of distinct interglacial soils in gravel deposits was carried out by Bibus \& STRAHL (2000) or Bibus \& KöSEL (2001) in the Rhine glacier area and the Bavarian-Swabian Danube valley.

\section{Regional Quaternary stratigraphy of Southern Bavaria}

Table 3 provides a short outline of the current Quaternary stratigraphy of Southern Bavaria. It is used particularly at the Geological Survey of the Bavarian Environmental Agency and largely also at Bavarian universities. Localities mentioned in the following text are given in Figure 1.

For a long time two different boundaries were applied in continental environments between the Pliocene and the Pleistocene:

(i) the internationally defined lower boundary of the Calabrian at 1.8 mio. yrs at the Vrica-section (AgUIRRE $\&$ PASINI 1985) or (ii) the boundary which is common in Central and NW Europe and which is connected to the first cooling phase in the Lower Rhine area (Praetiglian, ZaGwijn 1989) near the magnetic polarity change between Gauss and Matuyama epoch, currently at $2.58 \mathrm{Ma}$.

The alternating use of both boundaries in former publications may cause misunderstandings. For example the lower parts of the 'Uhlenberg section' were classified into the Pliocene by Ellwanger et al. (1994) but to Early Pleistocene by DOPPLER \& JERz (1995), whereupon the chronological ideas do not disagree. Other occurrences assigned to the Pliocene by former authors (e. g. EBERL 1930) were soon reclassified into the Quaternary. The reasons are mostly lithological affinities to other deposits of the Pleistocene and palaeogeographical considerations. A secure classification based on relative or numerical ages is so far only sporadically possible.

A division of the Pleistocene into the subseries Lower, Middle and Upper Pleistocene (= subepochs Early/Middle/ Late) is internationally established. In Bavaria a slightly different subdivision is used based on the regional climate stratigraphical classification (Tab. 3). 


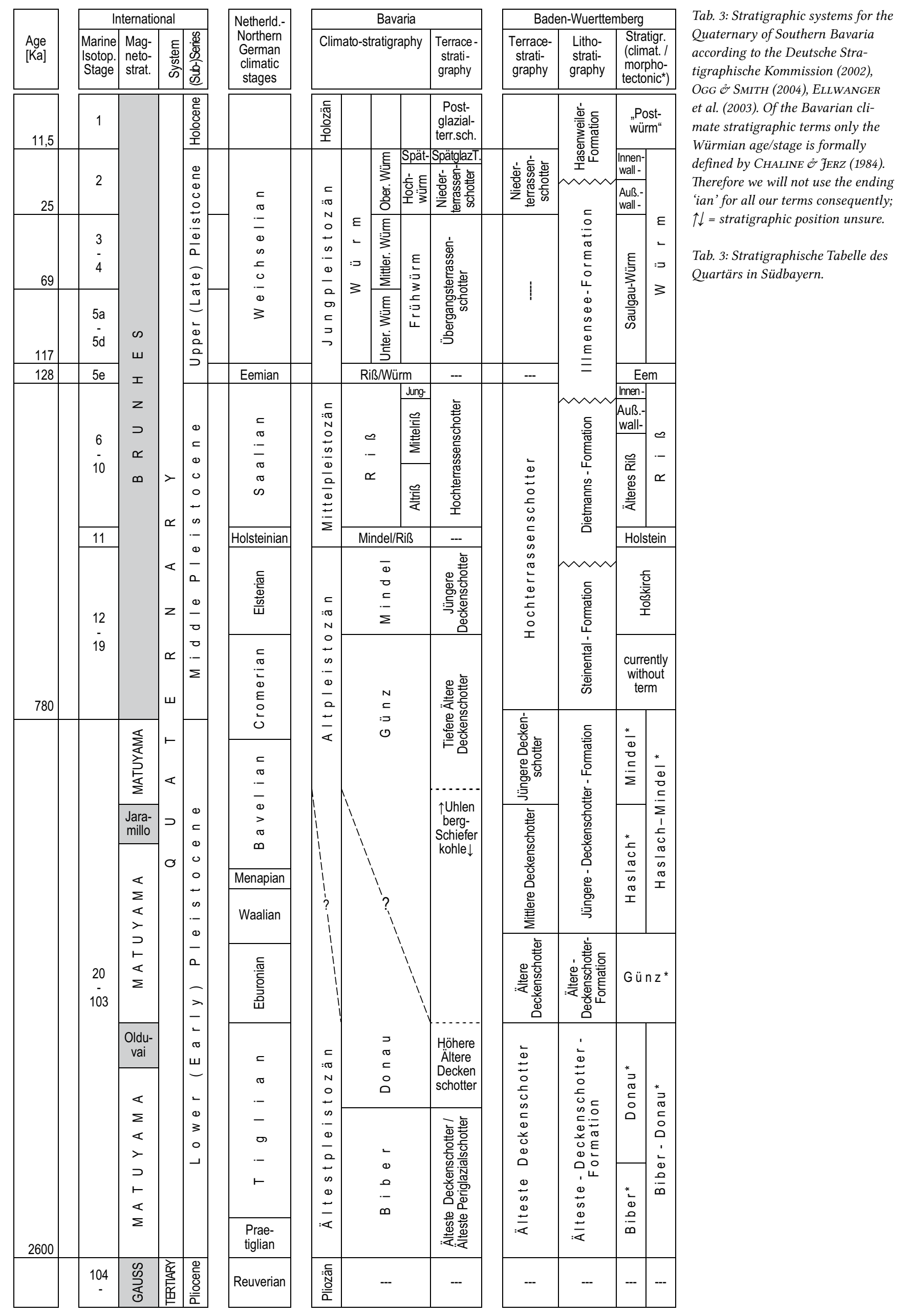




\subsection{Climate stratigraphy for Southern Bavaria}

\subsubsection{Biber ['Biberian']}

\section{First description.}

At the INQUA-Congress 1953 in Rome and Pisa SchAEFER (1955) presented a second extension of the formerly tetraglacial system of PENCK \& BRÜCKNER (1901/09). He assigned the gravel deposits of the 'Staufenbergschotter' (chronologically classified as 'Donau' by EBERL 1930) and of the 'Aindlinger Terrassentreppe' to a new glacial epoch named after the creek Biberbach north of Augsburg. By this, he followed the system of PENCK who labeled the glacial periods of the Quaternary using the names of rivers in descending alphabetical order from older to younger units.

\section{Current application.}

The term 'Biber' is currently used for the oldest period of the Bavarian Pleistocene ('Oldest Pleistocene') when the 'Alltester Deckenschotter' ('Oldest Cover Gravel') and probably also the 'Ältester Periglazialschotter' ('Oldest Periglacial Gravel') were accumulated. These include:

(i) gravel deposits like the 'Staufenbergschotter' near Bonstetten (NW of Augsburg),

(ii) the 'Hochschotter' and some lower gravel accumulations at the eastern border of the 'Aindlinger Terrassentreppe' (SW of Neuburg/Donau),

(iii) the wide-spread accumulation of the 'Staudenplattenschotter' (SW of Augsburg), which was assigned to the 'Donau' by Schaefer 1957,

(iv) the oldest periglacial gravel deposits in the Allgäu and in the area of the river Danube which are probably of similar age.

The 'Älteste Deckenschotter' are assumed to be connected to a first pronounced cold climatic stage following the Pliocene. But so far there is no direct evidence. However, the resemblance of the 'Älteste Deckenschotter' with younger glaciofluvial sediments argues for an accumulation during a phase of extended alpine glaciers. Also, the existence of large cobbles (up to $\sim 25 \mathrm{~cm}$ ) indicates a relatively close glacier front reaching into the foreland area.

The end of the 'Biber' coincides with the period of shifting pathways of the 'proto-Iller' from the area of the 'Staudenplatte' to the adjacent region of the 'Zusamplatte' in the Northwest. It remains doubtful, if the last episode of the 'Biber' coincides with a warm phase documented in the 'Bucher Schneckenmergel' or further flood deposits (see below).

\section{Type region and occurrence.}

The gravel deposits of the 'Staufenbergterrasse' and the 'Staudenplatte' are suggested as the 'Biber' type locality. Furthermore the remaining 'Älteste Deckenschotter' and the 'Älteste Periglazialschotter' including isolated finegrained flood deposits like the 'Bucher Schneckenmergel' are classified as 'Biber' (see also 3.2.2). These sediments occur as isolated relics on the top of the 'Alteste Periglazialschotter' below the 'Höhere Ältere Deckenschotter' (level of the 'Zusamplatte', see 3.2.3) and contain interglacial mollusc remains (MüNZING \& AKTAS 1986). These sequences occur on the Iller-Lech alluvial plain in the western part of the Alpine Foreland. East of the 'Aindlinger Terrassentreppe' no sediments corresponding with Biberian age were found so far.

\section{Dating and references.}

At present no numeric ages for the 'Biber'-type deposits are available. Mollusc-bearing reworked clods/lumps of marl in the 'Staudenplattenschotter' and at the top of the 'Alteste Periglazialschotter' enable just a correlation from Tiglian to Holsteinian after MüNZING \& AKTAS (1987). However, RÄHLE (1995) assumes a late Tiglian age for the fauna of the 'Uhlenberg' section which has to be younger than the Biber type deposits according to terrace stratigraphical relations. Hence the faunae of 'Biber'-type deposits must be older than the late Tiglian.

\subsubsection{Donau ['Danubian']}

\section{First description.}

The glacial period 'Donau', that means a corresponding complex of three cold phases was introduced by EBERL (1930) for gravel deposits which are located in a morphologically higher position than the 'Ältere Deckenschotter' near Memmingen. The latter are classified into the 'Günz' after PENCK \& BRÜCKNER (1901-1909). EBERL (1930) followed the nomenclature of PENCK (river names in alphabetical order) but with the Danube (Donau) he used a river outside his own investigation area, the southern Iller-Lech alluvial plain. According to EBERL (1930: 390, Tab. II) three 'Donau' stages correlate with minima of the Milankovićcurve between 800 and $650 \mathrm{ka}$.

\section{Current application}

The extent of the gravel deposits attributed to the 'Donau' glacial period has changed significantly since EBERL (1930) predominantly as a result of the investigations of SCHAEFER (1955) and Löscher (1976). Currently the period of deposition of the widespread 'Zusamplattenschotter' and its equivalents in the area of the Riß-Lech alluvial plain or of the 'Aindlinger Terrassentreppe' is described as 'Donau'. In the scheme of terrace stratigraphy these accumulations are called 'Höhere Ältere Deckenschotter' (Higher Older Cover Gravel). They have to be discriminated from the locally underlying channel fill gravel of probably periglacial genesis ('Ältester Periglazialschotter', Oldest Periglacial Gravel) and their partly conserved covering strata.

The termination of Donau to the 'Günz', a separating interglacial, is so far unclear. The 'Uhlenberg-Schieferkohle' (compressed peat; Fig. 2) is considered to document a warm period before the 'Günz', maybe even a Donau/Günz interglacial. However, correlation with the 'Tiefere Altere Deckenschotter' (Lower Older Cover Gravel) of 'Günz' age would be possible too.

The deposits classified as 'Donau' are interpreted as glacial meltwater deposits, although no unambiguous evidence for glaciations into the Alpine foreland during this period was found so far. Potential moraine-like deposits in the Denklinger Rothwald northwest of Schongau were classified variably during their investigation history as 'Mindel' (PENCK \& BRÜCKNER 1901-1909), 'Günz' (EBERL 


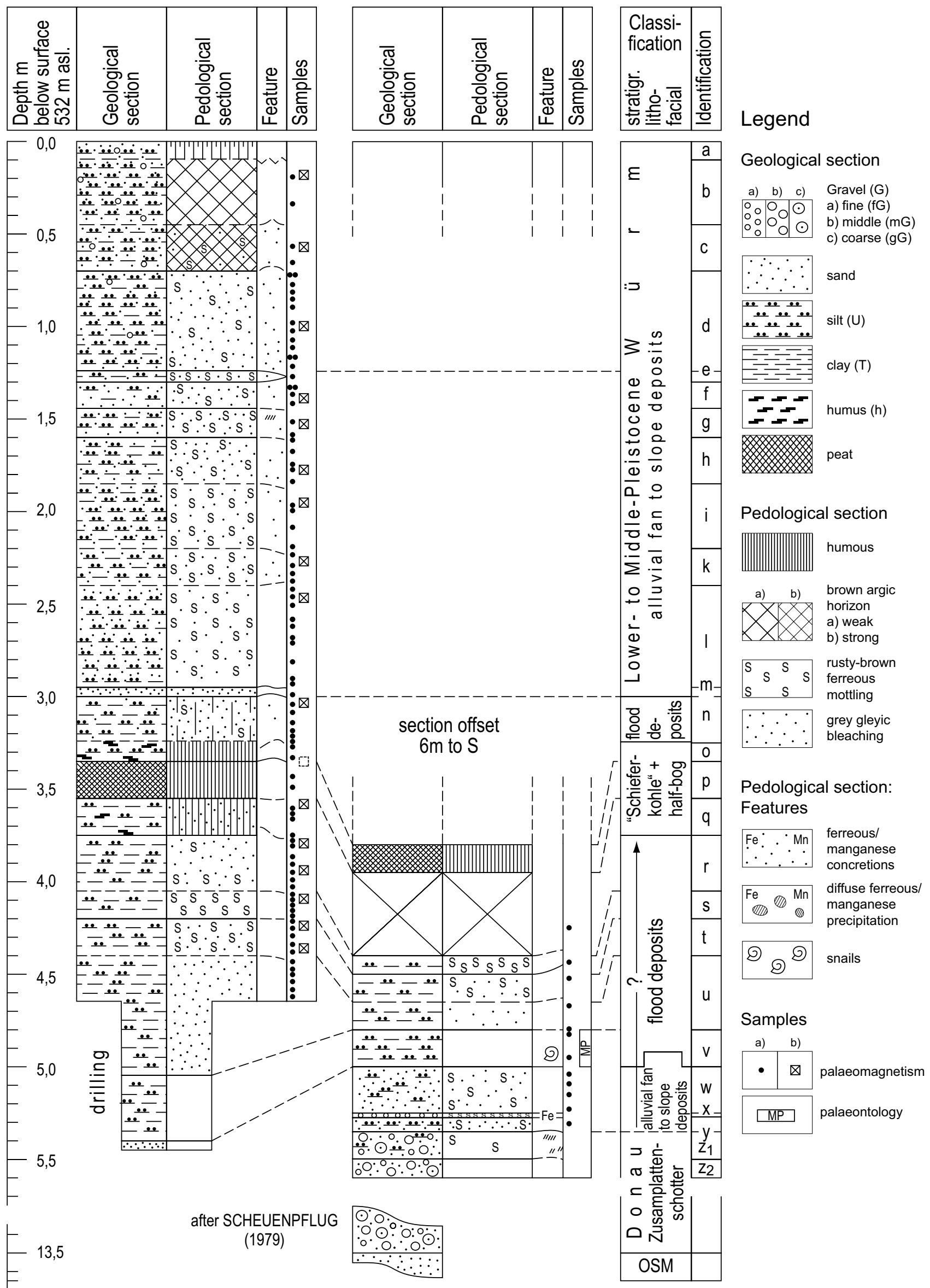

Fig. 2: Section of the covering strata of the gravel pit at Uhlenberg north of Dinkelscherben (after DOPPLER \& JERZ 1995). Abb. 2: Schichtenprofil der Kiesgrube am Uhlenberg N Dinkelscherben (nach DOPPLER \& JERZ 1995). 
1930: 280-281) or 'younger Donau' (RögNeR 1979, 88-91). Other possibly 'Donau'-aged moraines near Bickenried at the 'Höhen über Kaufbeuren' are described by RöGNER (1980). BeCKer-HaumanN (2005) assigns these moraines to the 'Günz', based on the fact that he inserts another glacial between Günz and Mindel, the so-called Haslach.

\section{Type region and occurrence.}

The sequence of the 'Zusamplattenschotter' is suggested as 'Donau' type region. This definition excludes locally preserved underlying 'Älteste Periglazialschotter' but includes overlying flood deposits. The status of the 'Uhlenberg-Schieferkohle' (Fig. 2) which developed from the latter is still an open question. Furthermore 'Höhere Ältere Deckenschotter' on the remaining Riß-Lech alluvial plain are classified as 'Donau', also including fine grained flood deposits at some places (see 3.2.3). Further, possibly Donau-aged deposits are found in the Danube area between Regensburg and Passau. So far a clear correlation with occurrences at the Riß-Lech alluvial plain is not possible. Neither loess-derived sections nor moraine-like sediments (RöGNER 1979) can clearly be assigned to the 'Donau' phase.

\section{Dating and references.}

So far numeric dating of 'Donau'-deposits is not possible. However, a relative classification based on magnetostratigraphic and biostratigraphic correlations is available.

(i) Palaeomagnetical investigations on the 'Zusamplatte' show a change from reversed to normal polarity in the lower sections of solifluctive loess loam in Roßhaupten and Lauterbrunn. It is interpreted as Matuyama/Brunhes boundary, i. e. the gravel deposits of the 'Zusamplatte' including the lower parts of their covering strata would be older than $780 \mathrm{ka}$. Normally oriented layers at the base of the Roßhaupten and the Uhlenberg section have been correlated with the Jaramillo event by BRUNNACKER et al. (1976). Recent results of STRATTNER \& RolF (1995) cannot confirm this. An age of more than $1 \mathrm{Ma}$ for the gravels of the 'Zusamplatte' in this regard is still a matter of debate.

(ii) The mollusc fauna in the upper parts of the gravel deposits of the 'Zusamplatte' and their fluvial covering strata suggest a Tiglian age (RÄHLE 1995).

(iii) Relics of small mammals in the overlying flood deposits at Uhlenberg belong to the mammal zone MN17 (upper Villanyium) according to ELLWANGER et al. (1994), which correlates with Tiglian (KöNIGSWALD $\mho$ HEINRICH 2007).

(iv) In contrast palynological analyses of the 'UhlenbergSchieferkohle' above the fossil-bearing flood sediments are considered to be significantly younger. BLUDAU (1995) suggests a correlation with the Bavelian originally defined in the Netherlands (ZAGwiJn \& DE Jong, 1985; see Tab. 3)

Accordingly, the 'Höhere Ältere Deckenschotter' and at least the lower part of their covering strata correlate with the younger Tiglian. The upper part of the covering strata and particularly the warm period represented by the 'Uhlenberg-Schieferkohle' seem to be considerably younger. As a consequence the 'Uhlenberg' section represents one or several interglacials which may be assigned to the end of the 'Donau' or the beginning of the 'Günz' period.

\subsubsection{Günz ['Guenzian']}

\section{First description.}

The terms 'Günz', 'Günz-glaciation' or 'Günz ice-age' date back to Penck \& BRÜCKner (1901-1909: 110). Deposits classified as 'Günz' by these authors are the 'obere' or 'ältere Deckenschotter' (upper or older Cover Gravel), e. g. the Böhener Feld southeast of Memmingen. PENCK assigned all glacial and fluvial sediments which he considered to be older than 'Mindel' to the 'Günz'. Gravel deposits in a more elevated position (e. g. at the Staufenberg) he explained by tectonic displacement.

\section{Current application.}

Currently 'Günz' is perceived as the episode between 'Donau' (including a terminal interglacial) and the 'Günz/ Mindel' warm period. The chronological range of 'Günz' is specified on the basis of rare gravel deposits in the area of the Riß-Lech alluvial plain ('Tiefere Ältere Deckenschotter' = Lower Older Cover Gravel). In Bavaria, so far no interglacial deposits were found which would allow defining a boundary between Günz and Mindel.

\section{Type region and occurrence.}

For 'Günz', no well-defined type region is apparent. To avoid miscorrelation it should be located in the area of the Riß-Lech alluvial plain near the type regions of 'Donau' and 'Mindel'.

The Günz-aged 'Zeiler Schotter' west of the Iller is characterised in detail by SCHREINER \& EBEL (1981) and appears well distinguishable due to position and composition. For the 'Heiligenberger Schotter' near Pfullendorf - considered to be of the same age - even a connection with till is verified (BIBus et al. 1996). However, the reversed magnetic orientation of younger occurrences ('Jüngere Deckenschotter' = Younger Cover Gravel) in the Heiligenberg area raises some doubt if the meaning of 'Günz' and 'Mindel' is the same in Baden-Württemberg and Bavaria. So far no 'Günz' or 'Mindel'-aged deposits were found in Bavaria which show a reversed magnetisation.

The so-called 'Zwischenterrassenschotter' (Intermediate Terrace Gravel) in the northwest of the Iller-Lech alluvial plain (Löscher 1976) are interpreted as continuation of the 'Zeiler Schotter' by Doppler (2003). But this correlation is not ensured. Classification is ambiguous also for other occurrences in the southern Iller-Lech alluvial plain. They do not offer good opportunities for a type section neither.

However in Southern Bavaria, apart from the Iller-Lech alluvial plain more occurrences of Günz-aged 'Deckenschotter' exist. In contrast to the rest of the Alpine Foreland in the area of the 'Münchner Schotterebene' deposits classified as 'Günz' occur in a normal stratigraphical sequence of gravels underneath sediments classified as 'Mindel'. A corresponding section including interstratified palaeosols is still observable in the 'Klettergarten Baierbrunn' (climbing park) south of Munich (JERz 1993: 33).

Gravel deposits assigned to the 'Günz' intercalated with moraine-like deposits appear in the area of the 'Hohe Altmoräne' in the northern region of the former Inn glacier between Haag and Dorfen (KöNIG 1979; GRIMM in prep.). Comparable deposits extend into the area of the former 
Salzach-glacier as gravel, till and basin sediments. The latter infill deeply incised channels near Trostberg according to drillhole data (EICHLER \& SINN 1974; Grimm et al. 1979; DOPPLER 2003b). For further occurrences see chapter 3.2.4.

In contrast to the better documented 'Glaziale Serien' of younger glacials the area of the Iller-Lech alluvial plain lacks evidence of 'Günz-'moraines. Only Roppelt (1988: 17) describes a very small occurrence southeast of Obergünzburg. Till deposits corresponding with 'Günz'-aged gravel can only be found in the more distant area of the former Rhine-glacier near Heiligenberg/Pfullendorf (BiBus et al. 1996) or further away in the area of the former Inn and Salzach glacier (KöNIG 1979; GRIMM et al. 1979). From Upper Austria KoHL (1998: 240, 297, 313) describes 'Günz' moraines and 'Alltere Deckenschotter' at the southern rim of the Traun-Enns alluvial plain. However, the correlation of these occurrences including the Rhine-glacier area is questionable.

Due to these uncertainties and the absence of well-defined overlying interglacial deposits the definition of a type region for 'Günz' is currently premature.

\section{Dating and references.}

So far in Bavaria neither numeric ages nor biostratigraphically evaluable localities are available for Günz-aged deposits. Palaeomagnetic analyses revealed reversed magnetisation of fine-grained sediments intercalated in moraines classified as 'Günz' near Pfullendorf in Baden-Württemberg (Fromm in BiBus et al. 1996). In contrast the analyses of loess loam on the Iller-Lech alluvial plain and of basin sediments connected to 'Günz' moraines in the valleys of rivers $\mathrm{Alz}$ and Traun resulted in normal polarity (STRATTNER \& Rolf 1995). This discrepancies may be due to miscorrelations and/or the fact that 'Günz' expands beyond the Matuyama/Brunhes-boundary. This seems realistic according to the classification of the 'Donau' and the 'UhlenbergInterglacial'. A reliable chronostratigraphical classification and correlation to the MIS-curve is not feasible.

\subsubsection{Günz/Mindel ['Günz/Mindelian']}

\section{First description and current application.}

PENCK \& BRÜCKNER (1901-1909: 111) called the warm period between the 'Günz' and the 'Mindel' glacials 'Günz/ Mindel-Interglacial'. In the current Bavarian climate stratigraphy the term 'Günz/Mindel' is still in use for this warm phase which so far is solely represented by relics of soil formation on top of Günz-aged deposits.

\section{Type region and occurrence.}

At present in the Northern Alpine Foreland no locality is suitable to define the Günz/Mindel interglacial by a pollen record. The following sections comprise parts with an assumed 'Günz/Mindel' age:

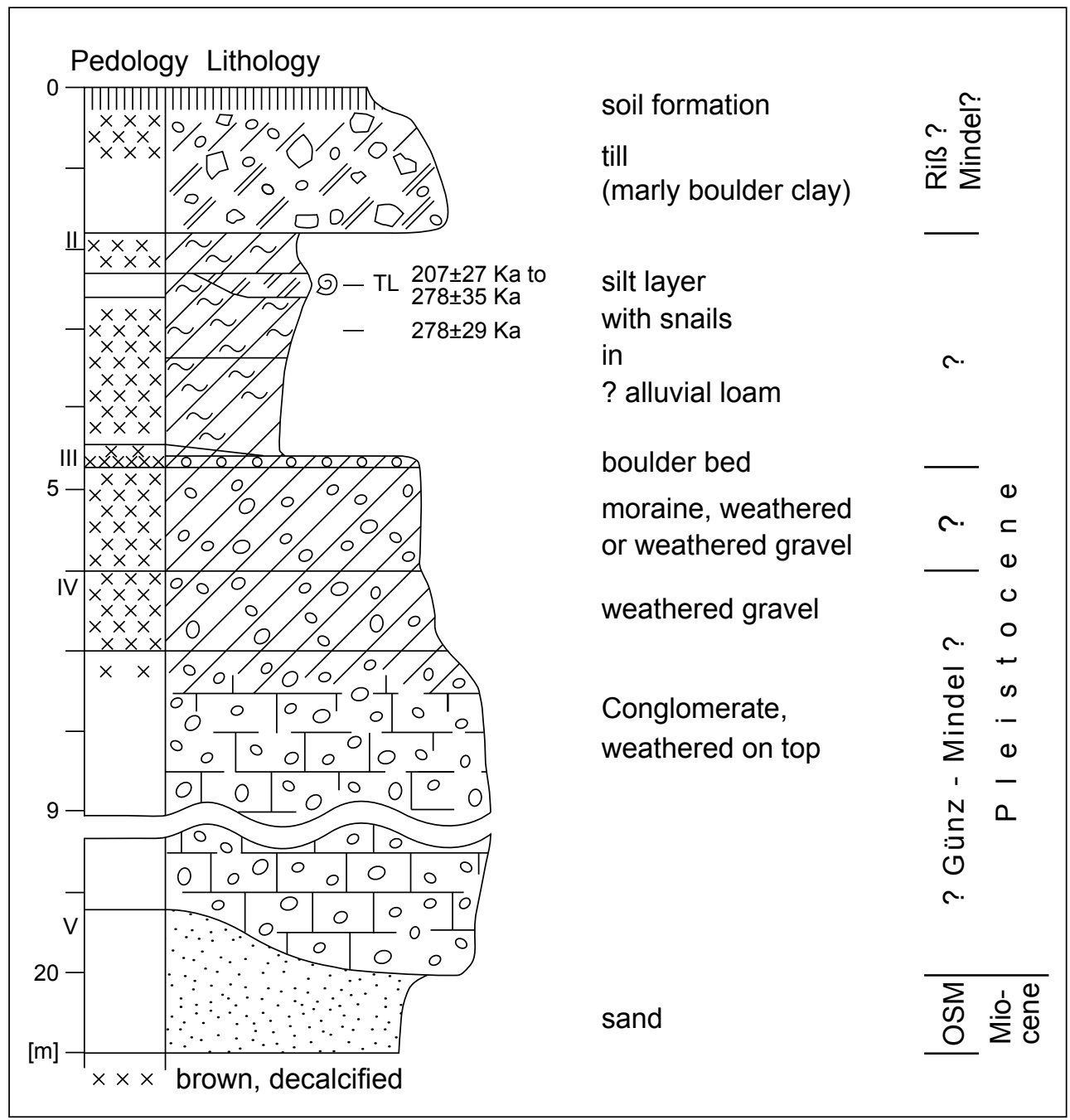

Fig. 3: Section at the ravine of Hinterschmalholz northwest of Obergünzburg after RÖGNER et al. (1988) and JERZ \& GROTTENTHALER (1995). The section shows the frequent problems of Quaternary stratigraphy: stratigraphical position and partly genetical interpretation of the units are controversial.

Abb. 3: Schichtenprofil im Bachtobel von Hinterschmalholz NW Obergünzburg nach RÖGNER et al. (1988) und JERZ \& GROTTENTHALER (1995). 
(i) a fossil soil on meltwater deposits below an eventually 'Mindel'-aged till of the Iller-glacier in the ravine of Hinterschmalholz south of Ottobeuren (Fig. 3; SINN 1972, RÖGNER \& LÖSCHER 1987, RÖGNER et al.1988); in contrast, a 'Riß' age is assumed for the till and a 'Mindel/Riß' age for the palaeosol by Roppelt (1988), JERZ \& GROTTENTHALER (1995);

(ii) a fossil soil on meltwater deposits below a till of 'Mindel' (or possibly 'Riß') age of the Lech glacier in the gravel pit Rau Täle southwest of Denklingen (RöGNER 1979);

(iii) geological pipes in the lowest sequence of the 'Deckenschotter' of the Isar-Loisach glacier in the 'Klettergarten Baierbrunn' south of Munich (JERz 1993: 33, Fig. 20);

(iv) a fossil soil on proximal meltwater to moraine deposits of the Inn glacier below the 'Jüngerer Deckenschotter' in the gravel pit Osendorf south of Dorfen (Doppler $\mho$ JERZ 1995: 44);

(v) a fossil soil probably below the 'Jüngere Deckenschotter' ('Vorstoßschotter') of the Salzach glacier in a road cut near Nock northwest of Altenmarkt (DopPLER 2003b).

\section{Dating and references.}

Due to the lack of datable deposits reliable information on a chronological position of the warm period at the end of the 'Günz' is presently missing.

\subsubsection{Mindel ['Mindelian' sensu lato]}

\section{First description.}

The terms 'Mindel', 'Mindel glaciation' or 'Mindel ice-age' date back to PENCK \& BRÜCKNER (1901-1909: 110) and describe a 'Glaziale Serie' from 'Altmoräne' to 'Jüngere Deckenschotter' south of Memmingen or alternatively at the valley of the river Mindel. Two levels of 'Deckenschotter' had already been discerned by PENCK (1899; see 3.2.4).

\section{Current application.}

The application of 'Mindel' in Bavaria corresponds largely with the original description. A period beginning with the decline of deciduous woodlands (not documented so far) subsequent to the 'Günz' and ending with the re-establishment of deciduous wood during the 'Mindel/Riß' is considered as 'Mindel'. However, west of the Iller Schreiner \& EBEL (1981) verified an additional glacial period between 'Günz' and 'Mindel' called 'Haslach'. The associa-ted 'Haslachschotter' (Haslach gravel) was assigned to the 'Jüngere Deckenschotter' already by PENCK \& BRÜCKNER (1901-1909). 'Haslach'equivalent deposits are supposed to exist also in Bavaria (BECKer-HaumanN 2005; HaBBe et al. 2007) but so far this classification could not be clearly confirmed. The 'Haslach' of the type region is separated from the underlying 'Günz' by a fossil soil and by the superimposed interglacial of Unterpfauzenwald from the 'Mindel' (sensu stricto = classification system of Baden-Württemberg). Deposits of assumed 'Haslach' age in Bavaria may have been classified preferably as 'Mindel' so far. Hence the 'Haslach' in Bavaria is considered as an early subunit of 'Mindel' (sensu lato = Bavarian classification system) subdivided by at least one warm period (Unterpfauzenwald).

A further climate/chronostratigraphical unit 'Hoßkirch' was introduced by ELLWANGER et al. (1995) into the classification system of Baden-Württemberg. It denotes the pe- riod of the lowermost Pleistocene basin deposits as shown by a drillhole at the basin of Hoßkirch, south to southwest of Saulgau. This new unit is documented palynologically as 'pre-Holsteinian'. At the same time 'Hoßkirch' is assumed to be younger than 'Mindel' because 'Mindel-aged 'Jüngere Deckenschotter' are situated in a higher position around the basin of Hoßkirch. For 'Hoßkirch' too, the occurrence of corresponding deposits is not yet verified in Bavaria and thus an integration in the climate stratigraphical classification of Bavaria would be premature. Deeply incised gravel deposits that are situated below the 'Alltere Hochterrasse' (see 3.2.6) may be assigned to a 'Hoßkirch' stage in the future.

\section{Type region and occurrence.}

The valley of the eponymous river Mindel lends itself as a type region for 'Mindel', almost literally in line with the descriptions of PENCK \& BRÜCKNER (1901-1909: 54). The moraines of the Holzheuer Höhe and the 'Oberegg-Saulengrainer Schotterzug' (string of gravel) demonstrate a classical 'Glaziale Serie' at the headwaters of the river Mindel. The gravel deposits merge with melt water channels of the same age near Mindelheim and continue as 'KirchheimBurgauer Schotter' along the Mindel-valley until reaching the Danube (Jerz et al. 1975; LösCher 1976; BECKERHAUMANN 2005: 218). The stratigraphical interpretation of the covering strata of the 'Kirchheim-Burgauer Schotter' in the brickyard-pit Offingen near the mouth of the river Mindel is still a matter of debate (cf. RöGNER et al. 1988, Bibus 1995). However, the assignment of the underlying 'Jüngerer Deckenschotter' to the 'Mindel' is without controversy. Near Kirchdorf east of Mindelheim the 'Mindel'-aged Nagelfluh is overlain by 'Riß-glacial' till. The two units are separated by a fossil interglacial soil (Doppler 1993, RöGNER 1993).

In search of a type region the area of the Rottal (BadenWürttemberg) has to be considered too. This particular area includes the type locality for the 'Haslach' glacial and the 'Haslachschotter, the 'Unterpfauzenwald interglacial' as well as the 'Tannheimer Schotter' ('Mindel' sensu stricto). Conditions are described in detail by SCHREINER \& EBEL (1981).

Depending on the stratigraphical interpretation of the uppermost till cover ('Mindel' after RöGNER et al. 1988: 70, or 'Riß' after Roppelt 1988: 98) different parts of the section at the ravine of Hinterschmalholz near Obergünzburg may represent 'Mindel' (see 3.1.4).

'Mindel'-aged gravel deposits, in particular the 'Jüngere Deckenschotter' (see 3.2.5), are widespread in the rest of the Bavarian Alpine Foreland with exception of the Tertiary hills of Lower Bavaria. Furthermore, some of the most distal segments of the 'Altmoräne' from the former Iller glacier (disputed), partly from the Isar-Loisach glacier and from the Inn- and Salzach-glacier area are classified as 'Mindel'. The deeply incised Alpine valleys and glacier basins in the foreland contain isolated remnants of basin or moraine deposits which are regarded older than 'Riß' and are thus possibly of 'Mindel' age (JERz 1979; FrAnK 1979). In the humid Alpine Foreland loess loam and other covering strata assigned to 'Mindel' are often masked by 'Pseudogley' sequences (stagnic cambisols or luvisols) which are hardly to differentiate (BRUNNACKER 1982; BiBUs 1995). 


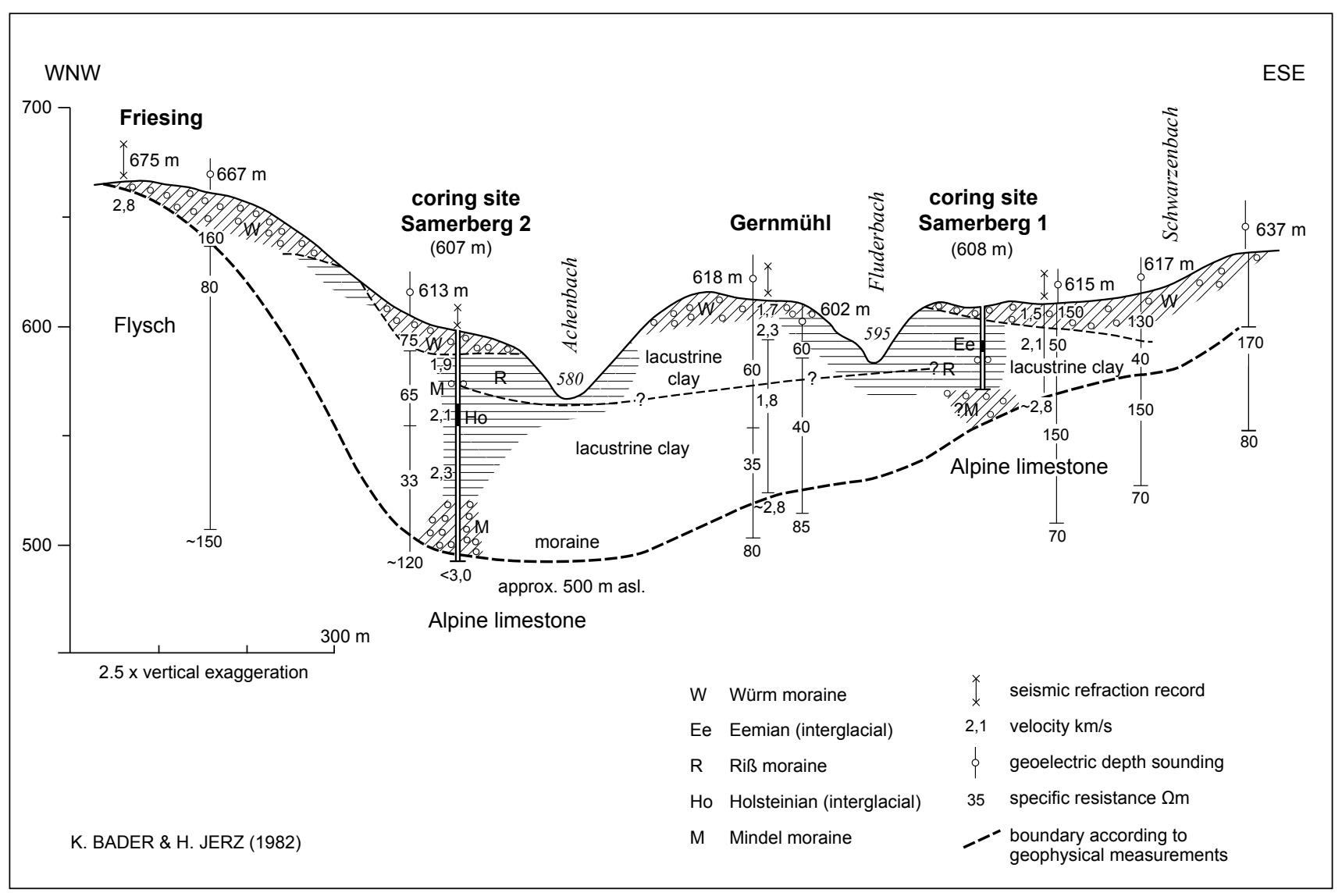

Fig. 4: Cross-section of the basin of Gernmühle (Samerberg) out of Rosenheim derived from geophysical measurements and the Samerberg research drillhole (from JERZ 1983).

Abb. 4: Profilschnitt durch das Gernmühler Becken auf Basis geophysikalischer Messungen und den Samerberg-Forschungsbohrungen (aus fERZ 1983).

\section{Dating and references.}

'Mindel' sensu lato probably has to be divided in two glacial phases, 'Haslach' and 'Mindel' sensu stricto. A reliable correlation with the MIS-curve for the whole extent is presently not possible. Probably only the upper termination can be linked to MIS 11 (or MIS 9?) by a correlation of 'Mindel/Riß' and 'Holsteinian'. This is in contrast to OSLdatings of sand layers in the 'Jüngere Deckenschotter' of the Mindel-valley near Offingen and Burgau which yielded ages of $260 \pm 24 \mathrm{ka}$ to $277 \pm 24 \mathrm{ka}$ (KLASEN 2008). However, the results of the applied method were considered as unreliable by the author herself. TL-dating in RöGNER et al. (1988) for a loess-like sediment sampled between overlying till deposits (not definitely classified as 'Mindel') and weathered loam in the ravine of Hinterschmalholz resulted in ages between $207 \pm 27 \mathrm{ka}$ and $278 \pm 36 \mathrm{ka}$. A similar age of $278 \pm 29 \mathrm{ka}$ is obtained from the underlying flood deposit. Methodologically these ages have to be taken as minimum ages. The first surface-burial dating-approach applied to the 'Grönenbacher Schotter' (HäUselmanN et al. 2007) yielded an age of $0.68+0.23 /-0.24 \mathrm{Ma}$. This singular and first time age certainly needs affirmation by further dating analyses.

Single magnetostratigraphical investigations provided inconsistent results and implicate a miscorrelation between gravel beds east and west of the Iller, both classified as 'Mindel' (or 'Haslach-Mindel'). In the 'Jüngere Deckenschotter' at the vicinity of Pfullendorf in the Rhine-glacier area a reversed polarity was yielded (pers. commun. D.
ELLWANGer). On the other hand sand layers in the 'Jüngere Deckenschotter' in the Salzach-glacier area showed a normal polarity (Strattner \& Rolf 1995; Doppler \& Jerz 1995). According to these explanations the classification of 'Mindel' and correlations of suspected 'Mindel'-aged deposits may be considered as highly uncertain.

\subsubsection{Mindel/Riß ['Mindel/Rissian']}

\section{First description and current application.}

The warm period between 'Mindel' and 'Riß' is described as 'Mindel/Riß' interglacial by PENCK \& BRÜCKNER (1901-1909: 111). 'Mindel/Riß' is mainly represented by very thick weathered soils compared to the 'Riß/Würm' interglacial. Therefore PENCK \& BRÜCKNER (1901-1909) called the 'Mindel/Riß' phase 'Großes Interglazial' (major interglacial). The authors assumed a relatively long duration for this period. The current conception about the course and termination of the 'Riß' has changed the chronological but not the stratigraphical position of this warm period. It is assumed to correspond with the 'Holsteinian' of the Northern European classification. Likewise the Holsteinian 'Mindel/Riß' encompasses a period of deciduous forests characterised by the presence of wing nut and beech (Pterocarya, Fagus).

\section{Type region and occurrence.}

So far in the Northern Alpine Foreland occurrences of interglacial deposits between 'Mindel' and 'Riß' are found only very sporadically, for example at the site of the drill- 
hole 'Samerberg 2' at the Bavarian Inn-glacier area (see Fig. 4; JERZ 1983; GRÜGER 1983), in the gravel pit 'Bittelschieß' at the Upper Swabian Rhine-glacier area (BLudAu in Ellwanger et al. 1999), and at the drillhole site 'Thalgut' in the Swiss canton Bern (Welten 1988; SChlüchter 1989). Neither underlying nor superimposed glacial deposits are dated so far and according to their basin position the interglacial deposits do not correspond with terrace systems. The classification of these sediments as Mindel/ Riß therefore depends exclusively on palynological analogies with the 'Holsteinian' in the area of the Nordic glaciation. Although the pollen record of Samerberg shows an incomplete succession its overall picture fits well into the generally known sequence. Hence the Samerberg is currently regarded as 'Mindel/Riß type section for the German Alpine Foreland.

Another peat layer situated between a deeply incised gravel accumulation and overlying gravel deposits of the 'obere Hochterrasse' southeast of Regensburg, the socalled 'Hartinger Schichten' (Harting layers) is described by Schellmann (1990). However, palynological investigations by Grosse-BeckMANN (1993) gave no clear evidence for the (chrono)stratigraphical classification of the peat. Possibly the Hartinger Schichten even extend below deposits of the 'Jüngere Deckenschotter'. Thus, a correlation with 'Günz/Mindel' has to be given consideration too.

Other occurrences of 'Mindel/Riß' in the Bavarian Alpine Foreland are restricted to palaeosols developed on 'Mindel'aged deposits. Loamy weathered gravel deposits have to be mentioned here, the 'Neufraer Boden' south of Riedlingen (BIBUS \& KöSEL 2001) or a palaeosol temporarily accessible at the construction site of the highway A96 east of Mindelheim (DOPPLER 1993, RöGNER 1993). Mindel/Riß-aged soils often reach into the conglomerate host rocks by metreslong pipes. In other places parts of the lower layers of loess loam sections have to be assigned to 'Mindel'. In general these interglacial soils have transformed to 'Pseudogley' (stagnic cambisols or luvisols; DOPPLER \& JERZ 1995).

\section{Dating and references.}

The correlation of the 'Mindel/Riß' interglacial of Samerberg and the 'Holsteinian' is based on the results of palynological investigations (GRÜGER 1983). The 'Holsteinian' in turn predominantly is thought to correspond with MIS 11 (approx. 420-360 ka). However, recently also a linkage to MIS 9 is suggested (e. g. GEYH \& MüLlER 2005). Numeric age determinations for the 'Mindel/Riß' interglacial are not available so far.

\subsubsection{Riß ['Rissian']}

\section{First description.}

The terms 'Riss' or Riss glacial are attributed to PENCK \& BRÜCKNER (1901-1909: 110, 398). Penck applied it for the 'Glaziale Serie' from 'Altmoräne' to 'Hochterrassenschotter', which he observed along the Riß valley near Biberach. However, the connection between moraine ridges and melt-water terrace they assumed was later refuted (see 3.2.6). Penck \& BRÜCKnER (1901-1909: 31, Fig. 3, 4) were aware of different levels of the 'Hochterrasse' but nevertheless considered the 'Riß' as an undivided glacial unit.

\section{Current application.}

In accordance with the official spelling of the small eponymous river in Upper Swabia the climate stratigraphical unit most commonly is spelled 'Riß', only sometimes 'Riss'. The whole period between the decline of woodland after the 'Mindel/Riß Interglacial' ('Holsteinian 1' at Samerberg according to GRÜGER 1983; 'Pterocarya interglacial' after DRESCHER-SCHNEIDER 2001) and the beginning re-establishment of forests during the 'Riß/Würm-interglacial' is considered as 'Riß'. Meanwhile there is widespread evidence for a subdivision of the 'Riß' into different ice advances, as it is for the Saalian. 'Holsteinian 2' at Samerberg according to GRÜGER (1983) for instance correlates with the Wacken/Dömnitz interglacial, part of the Saalian 'complex' (LiTT et al. 2007). However, a classification accepted by everyone and applicable to all 'Riß'-deposits is still lacking.

The subdivision of the 'Riß' is documented most explicitly at the type region selected by Penck - the Riß valley - as well as in other areas of the former Upper Swabian Rhine glacier (SChreiner 1989; Bibus \& Ellwanger 1995, Miara 1996, BiBus \& KöSEL 2001). A threefold subdivision into 'Älteres' ('Older Riß’; also 'Altriß’, 'Zungenriß’), 'Mittleres' ('Middle Riß'; also 'Mittelriß', 'Hauptriß', 'Doppelwallriß’) and 'Jüngeres Riß' ('Younger Riß’; also 'Jungriß’) is assumed. The 'Obere Hochterrasse' (morphologically higher; for instance $21 \mathrm{~m}$ above the valley bottom of the river Riß) originates from the 'Doppelwall' (double ridge) and the 'Untere Hochterrasse' (morphologically lower; $13 \mathrm{~m}$ above the valley bottom of the river Riß) from a terminal moraine, which should be situated backward but is not clearly identifiable. 'Älteres Riß' is represented by till and gravel deposits below embankments of the 'Doppelwallriß' and possibly also by advanced moraine-ridges (SCHREINER 1989). According to BiBus \& Kösel (2001) it appears likely that all the three cold phases of the 'Riß' are separated by different palaeosols which indicate interglacial conditions (Tab. 2).

In Bavaria subdivisions of the 'Riß' are obvious too. They are documented by different moraine stages partly attributed to glacier oscillations or by different levels of the 'Hochterrasse'. However, these subdivisions are not formalised on a supraregional scale. Particularly in the Salzach-glacier area the subdivisions of the 'Riß'-aged moraines (GRImm et al. 1979) seem comparable to those of the Rhine glacier. The 'Hochterrasse' in the Bavarian Alpine Foreland shows two terrace levels and an internal subdivision of the 'Obere Hochterrasse' (see 3.2.6).

\section{Type region and occurrence.}

The well-investigated Riß valley is regarded to be the type region, complemented by additional Upper Swabian sites (Schreiner 1989 to Bibus \& KöSEL 2001). 'Riß' is represented at many places in the Bavarian Alpine Foreland by tills and underlying gravel deposits of the ice-advance ('Vorstoßschotter'), while glaciofluvial terraces accompany most of the river valleys (cf. 3.2). Basin sediments and aeolian deposits on surfaces older than 'Riß' are to be mentioned too.

\section{Dating and references.}

'Riß' is positioned between the 'Mindel/Riß' interglacial (= Holsteinian of Samerberg) and the 'Riß/Würm' intergla- 
cial (= Eemian). The latter is clearly identified at some locations in the Bavarian Alpine Foreland. 'Riß' probably correlates with the multi-phased Northern German 'Saalian' and thus encompasses the MIS 10 to MIS 6. So far no numeric dates of the intra-'Riß' warm phases are available because they are represented only by soil remnants. Tentatively they correlate with MIS 9 and MIS7.

At present only luminescence methods are available for numeric dating of deposits classified as 'Riß'. The few samples dated so far yielded ages of about 280 to $110 \mathrm{ka}$ (FIEBIG \& Preusser 2003; Klasen 2008). The beginning and the termination of the 'Riß' is defined by the delimiting interglacials, which provide improved dating opportunities. Their correlation with MIS 11 and MIS 5e results in a time span between 360 and $128 \mathrm{ka}$ for 'Riß'.

\subsubsection{Riß/Würm ['Riss/Wuermian']}

\section{First description and current application.}

PENCK \& BRÜCKNER (1901-1909: 111) use the term 'Riß/ Würm' interglacial for the warm period between the 'Riß' and the 'Würm' glacials. They found it documented as a phase of incision into the older terrace deposits and in form of palaeosols. Besides this traditional perspective, the 'Riß/ Würm' warm period can be classified biostratigraphically and by numeric ages nowadays. The 'Riß/Würm' interglacial encompasses the forested phase between 'Riß' and 'Würm'. Its climax stadium is characterised by increased portions of yew (Taxus). Frenzel (1978) assumed two different interglacials responsible for palynologically different types of 'Riß/Würm' interglacial occurrences in the Alpine Foreland ('type Zeifen' and 'type Pfefferbichl'). According to Drescher-SchneIder (2000a) the difference is probably based on diverse forest communities depending on the altitudinal zone. So actually a 'Tieflandtyp' (lowland type) and a 'Alpiner Typ' (alpine type) may be discerned.

The correlation with the Eemian in the area of the Nordic glaciation is assured and this term is commonly used for the area of the Alpine glaciation too. However, the term 'Riß/Würm' is prefered here because it fits into the Alpine classification system and allows for possible variations due to different environments in both regions.

\section{Type region and occurrence.}

Due to its completeness and its diversification the most suitable type location of the 'Riß/Würm' interglacial is the profile of the lake sediments at Samerberg (JERz 1979; GrüGER 1979). The Mondsee section at the Salzkammergut/ Austria (Drescher-SchneIDER 2009b) is regarded as comparably complete and even shows the succeeding development of the 'Early Würm'.

Further well-investigated but less complete sequences of 'Riß/Würm' deposits occur as lake marls or 'Schieferkohle' (compressed peat) at the following sites: Zeifen east of Lake Waging (Jung et al. 1972), Eurach south of Seeshaupt at the Starnberger See (former 'Würmsee'), Großweil east of Murnau, Herrnhausen south of Wolfratshausen, and Pfefferbichl near Buching (all mentioned in BAYERISCHES Geologisches Landesamt 1979, 1983). Another example of 'Riß/Würm'-aged deposits is the calcareous sinter ('Kalktuff') at the river Lech near Kolonie Hurlach north of Kaufering, which contains an interglacial mollusc fauna (KovANDA 1989).

The 'Riß/Würm' is also widespread in form of palaeosols, sometimes even called 'Eemboden' (Eemian soil). These palaeosols (e. g. 'Rosnaer Boden' after BiBus \& KösEL 2001) occur on gravel deposits and moraines of the 'Riß' phase. The Riß/Würm soil is often the only well discernable interglacial soil in loess loam sections of the humid Alpine Foreland. Older palaeosols are difficult to distinguish because in most cases they are amalgamated to thick packets of Pseudogley (Stagnic Cambisol or Luvisol).

\section{Dating and references.}

The 'Riß/Würm' correlates palynologically and according to numeric ages with the Eemian of the Nordic classification system and therefore with MIS 5e. Palynological analyses on peats (in part called 'Schieferkohle') are mentioned above and in Table 1. It should be noted that also an interstadial origin has to be taken in account for some of the peat layers of the Alpine Foreland. Peat and the calcareous sinter of Hurlach are dated by the U/Th-method (JERZ 1993: 82; JERZ o MANGelsDorf 1989; Doppler 2003b). The results point to a period of formation between approximate 125 and $100 \mathrm{ka}$. So, in part the deposits are younger than the assumed duration of the 'Riß/Würm'-interglacial and their formation may have continued to the earliest parts of the 'Würm'.

\subsubsection{Würm ['Wuermian']}

\section{First description.}

The terms 'Würm', 'Würm glaciation' or 'Würm ice age' were introduced by PENCK \& BRÜCKNER (1901-1909: 110). Penck uses it for the 'Glaziale Serie' of the last glaciation that can be traced from the younger moraines of the Illerglacier into the 'Memminger Tal'. In order to continue with his concept of naming glaciations in an alphabetical order he selected the Würm, a small river west of Munich which crosses the younger moraine ridges of the Lake Würm lobe (part of the Isar-Loisach glacier) and the adjacent Würmaged alluvial plain of the 'Münchner Schotterebene'. Like the other glacials PENCK \& BRÜCKNER (1901-1909) considered the 'Würm' glacial as single-phase event. Thus their 'Glaziale Serie' primarily encompasses only the comparatively short pleniglacial period.

\section{Current application.}

Currently the whole period between the decline of woodlands after the 'Riß/Würm'Interglacial and their re-installation in the Holocene is considered as 'Würm'. Since the first definition by PENCK \& BRÜCKNER (1901-1909) different ideas emerged concerning the development and subdivision of the 'Würm'. This paper cannot refer to all of these conceptions.

Since 1983 the 'Würm' is subdivided formally into 'Unteres' (Lower), 'Mittleres' (Middle) and 'Oberes (Upper) Würm' (Chaline \& JERz 1984). The 'Lower Würm' starts with the decline of woodlands after the 'Riß/Würm'-interglacial (pollen zone 13 in the Fluderbach section at Samerberg). It lasts until the end of the second interstadial of the 'Lower Würm' (pollen zone 25 of core Samerberg 1; GRÜGER 1979). The succeeding decline of trees (pollen zone 
26) initiates the 'Middle Würm' whose end is defined as the lithological change of pelitic pond sediments to overlying gravel at the locality Baumkirchen at the Tirolean Inn valley. The gravel was deposited in front of the advancing Inn glacier ('Vorstoßschotter'). The 'Upper Würm' ranges to the Pleistocene/Holocene boundary as formally defined at a Greenland ice core (WALKER et al. 2009).

In Bavaria, due to a lack of palynological data for most of the 'Würm' aged deposits, a pragmatic classification is applied. Instead of palynological features the last glacial advance into the Alpine Foreland is used as criterion for the division into 'Frühwürm' (Early Würm), 'Hochwürm' (Würm Pleniglacial) and 'Spätwürm' (Late Würm). 'Frühwürm' encompasses the whole period between the 'Riß/ Würm' and the glacial advance of the 'Hochwürm'. The term 'Frühwürm' elsewhere - e. g. in Switzerland - however is used synonymic for 'Unteres Würm' ('Lower Würm'). The lower boundary of the 'Upper Würm' is conform to the 'Hochwürm'. However, concerning the gravel accumulations in front and below the advancing glaciers a clear separation of 'Early Würm' and 'pleniglacial' parts is mostly impossible like in the area of the former Loisach-glacier (DrEESBACH 1986). According to the Bavarian classification all sediments of the 'Würm' deposited after the ice retreat from the 'Innere Jungendmoräne' (= internal terminal moraines of the Pleniglacial) are assigned to the 'Late Würm' (CHALINE \& JERz 1984: 191). This corresponds only roughly with other definitions for the lower boundary of the 'Late Würm':

(i) by the retreat from younger ice margins like the 'Ammerseestadium' of the former Loisach glacier or

(ii) by palynological criteria. According to palynology glaciers had already retreated into the alpine valleys at the beginning of the 'Late glacial' (cf. FELDMANn 1994: 234).

\section{Type region and occurrence.}

At the conference of the Subcommission of European Quaternary Stratigraphy (SEQS) in 1983 a type region of the 'Würm' was constituted in the area of the former Inn glacier including the localities Baumkirchen and Samerberg and the former Isar-Loisach glacier with its terminal moraine ridges around the Starnberger See or 'Würmsee' (Chaline \& Jerz 1984). The 'Lower', 'Middle' and 'Upper Würm' are defined at the locations mentioned above.

The three units 'Frühwürm' (Early Wuerm), 'Hochwürm' (Pleniglacial) and 'Spätwürm' (Late Wuerm), especially the boundary between the latter units however are not defined at certain localities. Because of varying response times of glaciers to climate changes there may be minor differences concerning the chronology of different glacier lobes.

In the Bavarian Alps and the Bavarian Alpine Foreland deposits of the 'Würm' glacial are widespread and encompass different glacial remnants like glacio-lacustrine deposits in the deeply eroded alpine valleys and foreland basins and moraines of different characteristics. In the valleys melt-water deposits like 'Niederterrassen' and 'Spätglazialterrassen' but also 'Übergangsterrassen' (see 3.2.8, 3.2.9, 3.2.7) are classified to 'Würm'. Additional periglacial deposits of autochthonous valleys and other periglacial sediments have to be kept in mind, especially aeolian deposits like loess loam and loess to sand drift.
Dating and references.

The correlation of the 'Würm' with MIS $5 \mathrm{~d}$ to 2 is beyond dispute and documented by numeric ages and palynological correlations. For the two older interstadials at Samerberg GRÜGER (1979) finds a correlation with the Brørup (MIS 5c) or the Odderade (MIS 5a) from the Nordic classification. With exception of an ambiguous third interstadial at Samerberg the sequence of MIS 4 to 3 is not yet resolved very well, even not in Baumkirchen.

However, plant remains derived from the varved clays at Baumkirchen were dated by radiocarbon. They document ice-free conditions in the Inn-valley until at least $25 \mathrm{ka} \mathrm{BP}$. $27 \mathrm{ka} \mathrm{BP}$ is the youngest uncorrected radiocarbon age from the clay pit Baumkirchen, still several tens of metres below the front of proximal glacio-fluvial gravels (FLIRI 1983, PATzelt \& Resch 1986). The retreat from the 'Innere Jungendmoräne' and thus the beginning of the late glacial is not clearly defined. The Inn valley near Innsbruck was icefree at around $14 \mathrm{ka} \mathrm{BP}$, in accordance with first organic sedimentation in the Lanser See (BORTENSCHLAGER 1984). In the basin of the Murnauer Moos ice-free conditions are suggested from around $16 \mathrm{ka}$ BP (SCHNEIDER 2006: 289). Thus the climatic conditions probably ameliorated clearly before $16 \mathrm{ka} \mathrm{BP}$ and brought about the ice retreat from the 'Innere Jungendmoräne'.

For a current classification of the Upper Pleistocene in Switzerland, based on luminescence and cosmogenic nuclide dating, see Preusser (2004) and Ivy-Ochs (2004).

\subsubsection{Holocene}

Superordinate chronostratigraphical units like Pleistocene and Holocene are defined internationally (WALKER et al. 2008). The comment on the chronostratigraphical series Holocene thus may be restricted to regional aspects.

\section{Current application.}

So far a subdivision of the Holocene into subseries or stages (e. g. BortensCHLAGER 1982) is not formalised internationally. The sub-division of the Holocene used in Bavaria refers to the pollen record of Central Europe (FIrBAs 1949, 1952). 'Preboreal' and 'Boreal' (pre-warming period and early warming period) are summarised as Early Holocene and 'Atlantikum' and 'Subboreal' (warming period and late warming period) as Middle Holocene. The Late Holocene correlates with the 'Subatlantikum' (post-warming period). Instead of the formal term 'Holocene' for the youngest still persisting episode in earth's history the name 'Postglazial' (Post Glacial) is often used in Bavaria, especially to name Holocene river terraces ('Postglazialterrassen'; see 3.2.10). The subdivision into early, middle and late Postglacial correlates with the classification into Early, Middle and Late Holocene, but there are no exact boundaries.

The Holocene encompasses the period of human settlement when men influenced significantly the ecosystem. Pollen grains e. g. of common hop/hemp (humulus/cannabis) in the Ammersee document the beginning of horticulture during the Boreal (KLEINMANn 1995). At the river valleys human influence is traceable by wide-spread floodplain deposits ('Auenablagerungen'). Those fine-grained flood deposits are primarily attributed to outwash events in consequence of for- 
Fig. 5: Schemes of terrace-flights of the Northern Alpine Foreland in Bavaria and partly Württemberg (without scale).

Abb. 5: Schematische Darstellung der Terrassentreppen des bayerischen (und württembergischen) Alpenvorlands (ohne Maßstab).

Fig. 5a: Proximal region (around Iller-Lech alluvial plain).

Abb. 5a: Proximaler Bereich (etwa Gebiet der Iller-Lech-Platte).

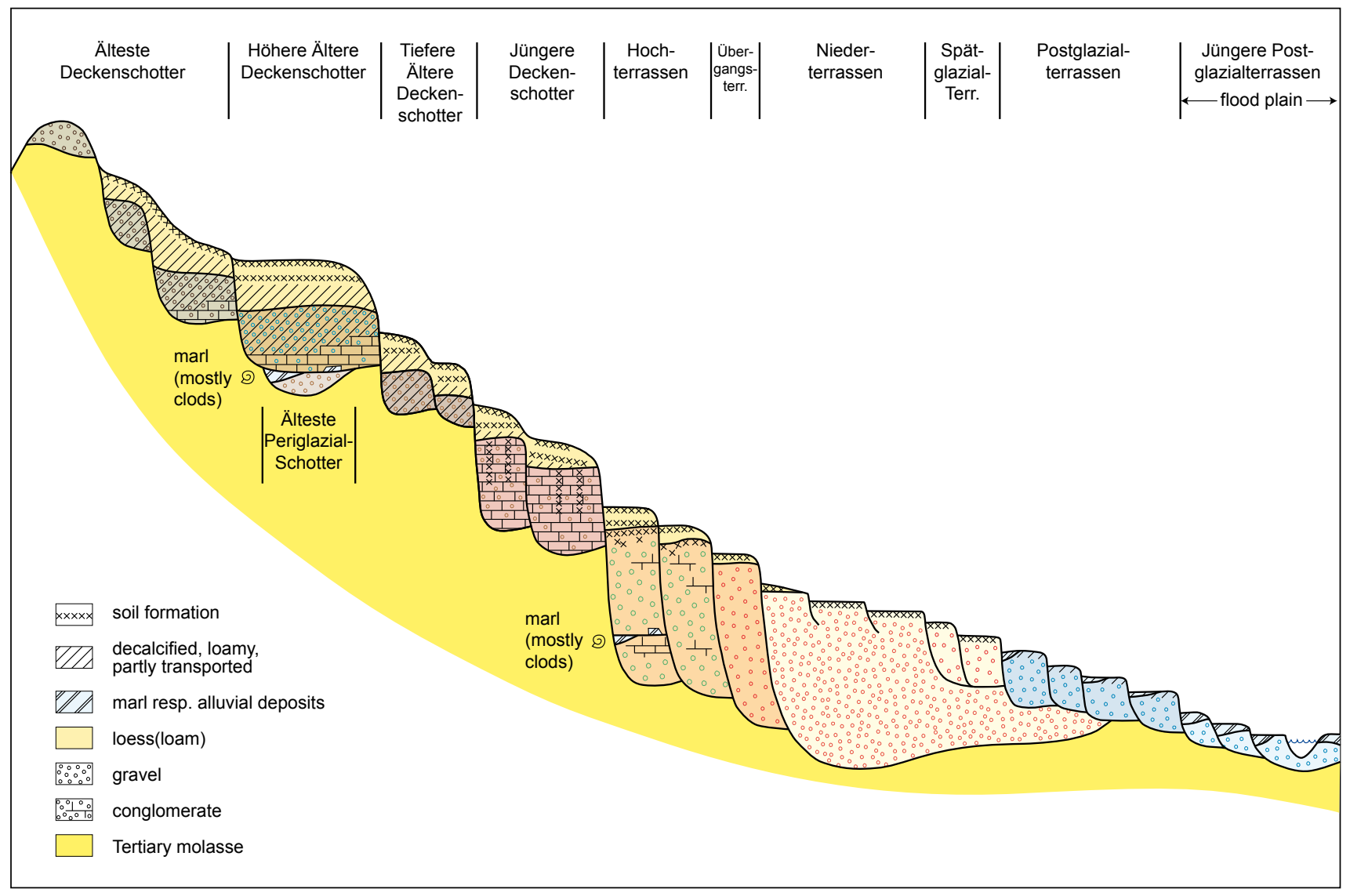

Fig. 5b: Distal region (around Dungau; changed after SCHELLMANN et al. 2010: Fig. 19, 20).

Abb. 5b: Distaler Bereich (etwa Dungau; verändert nach SCHELLMANN et al. 2010: Abb. 19, 20).

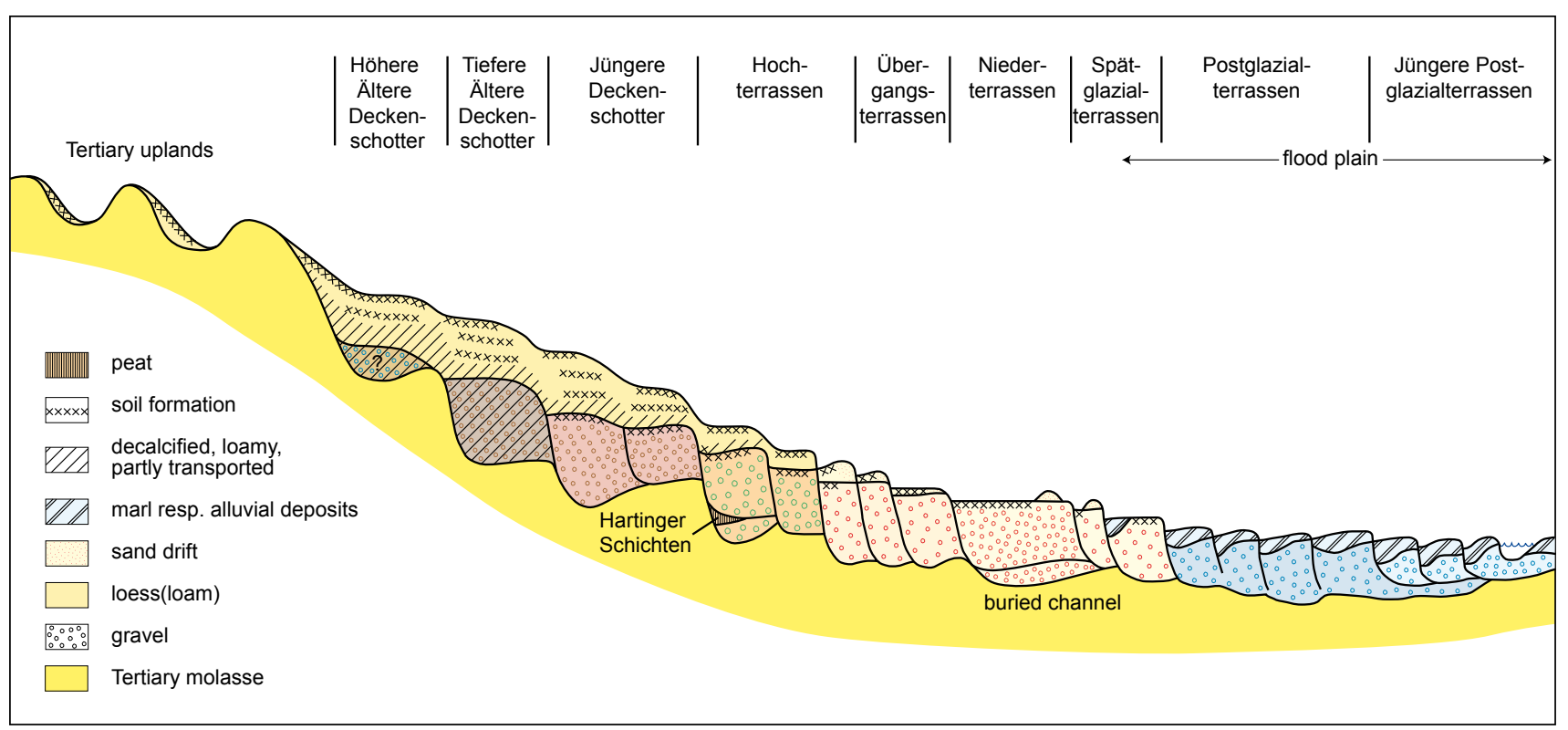


est clearing for the expanding agriculture since the Bronze Age (late Subboreal). Floodplain deposits - which are largely but not solely restricted to the Late Holocene - often display the only chronological subdivision of Holocene presented on geological maps apart from artificial accumulations. The early and the middle Postglacial are not clearly to distinguish without dating. River corrections and regulations primarily during the last 200 years brought an end to the natural dynamic of most of Bavaria's watercourses.

\section{Occurrences.}

In Bavaria Holocene deposits occur mainly as river sediments along most of the active watercourses. In addition Holocene lake deposits, peat bogs, calcareous sinter or redeposited material like aeolian drift sands, outwash-sediments and accumulations from mass movements can be discerned.

The geomorphodynamics during warm periods like the Holocene differ significantly from processes of the cold phases. Warm phases are characterised by a widely closed vegetation canopy, an active body of groundwater, and a resulting tempered run-off regime. Meandering rivers are documented by widespread terrace-sequences. At the lower reaches of the alpine rivers and in the Danube-valley terraces show only marginal differences in altitude ('Reihenterrassen' after SCHIRMER 1983). Sedimentological analyses combined with datings argue for a river dynamic which varied considerably during the Holocene. As the associated changes appear almost synchronously in all river systems of the Northern Alpine Foreland terrace development seems to be triggered by climatic changes.

\section{Dating and references.}

The Holocene encompasses the last $11.5 \mathrm{ka}$ which is a comparatively short period with respect to the geological time scale. For classification or numeric age dating of Holocene deposits various methods exist depending on the material, like palynology, radiocarbon dating, luminescence dating, stable isotopes, dendro-chronology and archaeological and historic techniques. Thus, a high-resolution anatomy of this period is possible.

\subsection{Terrace stratigraphy for Southern Bavaria}

\section{General information.}

In Bavaria the terrace stratigraphy (classification by means of different terrace levels) applies the concept introduced by PeNCK (1882) and PENCK \& BRÜCKNer (1901-1909). In later years the terrace stratigraphical system was extended by JERz et al. (1975) and Schellmann (1990) as is demonstrated in Table 4. Younger terrace deposits at the valleys are distinguished from older 'Deckenschotter' (approximately 'cover gravel') generally capturing the ridges between the valleys. However, in contrast to the original intention of the denomination it is not evident that 'Hoch-' and 'Niederterrassen' are restricted to valleys and 'Älteste' to 'Jüngere Deckenschotter' mainly occur as sheet-like deposits (see Fig. 5). The widespread 'Niederterrasse' of the alluvial plain of Munich ('Münchner Schotterebene') and the 'Jüngere Deckenschotter' of the Mindel-valley, which is delimited like a terrace, may be cited as examples (PENCK
1899). The terms 'Hochterrasse' to 'Postglazialterrasse' are describing (geo)morphological forms after all. But at the same time they often are used for the associated sedimentary units (SCHELLMANN 1990).

The terrace deposits of the Bavarian Alpine Foreland are predominantly composed of gravel with an Alpine provenance. Depending on the catchment area there are considerable variations especially concerning the ratio between carbonate and crystalline rocks. Gravel deposits of the same age may show a totally different composition. If the catchment of a glacier extends well into the Central Alps the amount of crystalline rocks generally increases towards the younger deposits. The absence of easily weathering dolomite and an enrichment of components resistant against weathering and transport are used for identification of periglacial gravels ('Liegendfazies' cf. LÖSCHER 1976; 'Molassekristallinfazies' cf. DopPler 2003a). Fresh glacio-fluvial gravel deposits ('Hangendfazies' respectively 'Alpine Karbonatfazies') usually show nearly complete spectra of carbonaceous Alpine rocks, including dolomite. The river Danube along its course incorporates rocks of the Black Forest, the Alb region, and the eastern Bavarian crystalline basement. This enables an identification of former stream courses ('Urdonau' = proto-Danube cf. Scheuenpflug 1971; 'Weißjurafazies' cf. Löscher 1976).

Recent synopses of the gravel occurrences in the Bavarian Alpine Foreland including a detailed documentation of literature are provided by DOPPLER (2003), RöGNER (2004), Becker-Haumann (2005) and Schellmann (2010). Some of the expansive interpretations of BECKER-HAUMANN (2005) are not adopted here (e. g. concerning the origin of the 'Weißjuraschotter', the diversification of the 'Staudenplattenschotter' or of the 'Grönenbacher Feld').

\subsection{1 Ältester Deckenschotter ['Oldest Cover Gravel']}

\section{First description.}

For the first time the term Altester Deckenschotter is applied probably by JERz et al. (1975) as an extension of Penck's 'Deckenschotter' classification. The term denotes Pleistocene gravel deposits situated in the highest morphological positions of the Iller-Lech alluvial plain. However, JERZ assigns these accumulations partly to the 'Donau' glacial.

\section{Current application.}

The term is currently used by the Geological Survey in Bavaria for gravel deposits which correlate with terrace levels from the Staufenbergschotter down to the Staudenplattenschotter and are considered to be of 'Biber' age. This is in accordance with the reclassification of large parts of 'Ältere Deckenschotter' of the Iller-Mindel alluvial plain into the 'Donau' glacial by Löscher (1976). According to their altitude levels occurrences of the 'Älteste Deckenschotter' are described as 'Hochschotter', 'Oberer Deckschotter' and 'Mittlerer Deckschotter' by GRAul (1949) and students as well as by SCHAEFER (1953). In contrast to DOPPLER \& JeRz (1995) the 'Hochschotter' is summarised here too. Notwithstanding, in Baden-Württemberg the term is applied at the same time for 'Deckenschotter' of Donau age in the level of the 'Zusamplatte' (e. g. Erlenmooser and Erolzheimer Schotter). 


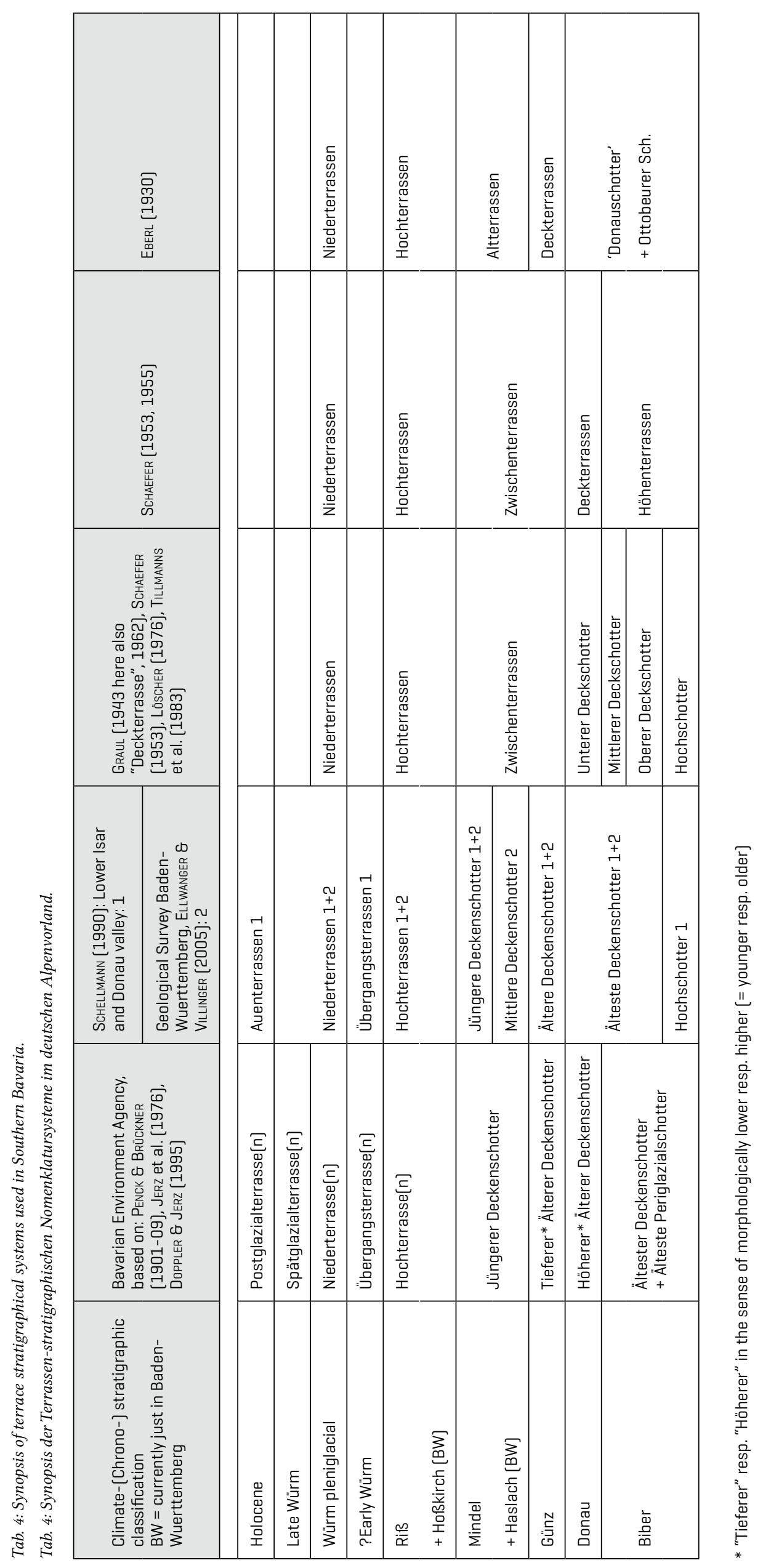


Type region and occurrence.

The gravel deposits of the 'Staufenberg-Terrassentreppe' and the 'Staudenplatte' are suggested as type region for the 'Alteste Deckenschotter'. This unit has to be subdivided in probably at least three terrace-levels of different age: 'Höchste Älteste Deckenschotter' (= 'Hochschotter'; Highest Oldest Cover Gravel), 'Höhere Älteste Deckenschotter' (= 'Obere Deckschotter'; Higher Oldest Cover Gravel) and 'Tiefere Älteste Deckenschotter' (= 'Mittlere Deckschotter'; Lower Oldest Cover Gravel). Each of them needs an appropriate type locality.

The localities 'Hochfirst' on the Iller-Lech alluvial plain, 'Arlesrieder Schotter', 'Staudenplatte', 'Staufenberg-Terrassentreppe' and the 'Aindlinger Terrassentreppe' (flight of terraces) are counted among the occurrences of the 'Alteste Deckenschotter' in Bavaria. They all are attributed to the proto-Iller which extended in south-western to northeastern direction to the present lower-end of the river Lech.

East of the mentioned occurrences on the Iller-Lech alluvial plain gravel accumulations indicating definitely an appropriate old age are so far not identified. Just along the former stream course of the Danube small elevated gravel deposits are described. A diversification from residual gravel deposits ('Restschotter') of the Miocene Upper Freshwater Molasse or possible Pliocene accumulations sometimes is difficult here because of complete weathering (e. g. Tillmanns 1977; Hilgart 1995).

\section{Termination and lithology.}

The 'Ältester Deckenschotter' displays the occurrence of glacio-fluvial gravel deposits most elevated in the Northern Alpine Foreland. Older gravel deposits are of Miocene (Upper Freshwater Molasse) or Pliocene origin. Their pebble composition is dominated by Quartz and thus they are to distinguish from fresh carbonaceous 'Ältester Deckenschotter'. The unit following the 'Älteste Deckenschotter' is the 'Höhere Ältere Deckenschotter' (Zusamplattenschotter and equivalents). Surface and base of this accumulations are situated more than $10 \mathrm{~m}$ lower than 'Älteste Deckenschotter'.

The 'Älteste Deckenschotter' is mostly decalcified and in general shows a completely weathered and partly loamy/ silty residual gravel deposit. It is only rarely preserved as conglomerate. For the larger part the deposits are strongly dissected and affected by erosional processes. Mentionable covering strata of aeolian origin are just located at better preserved areas (e. g. near Markt Wald). But no section with a stratification according to the old age of these deposits has already been found.

\section{Classification and correlation.}

So far no direct numeric or relative datings of the 'Älteste Deckenschotter' are available. Only clods of marl in the 'Staudenplattenschotter' near Fischach and Walkertshofen (EBERL 1930: 309; SCHRÖDER \& DEHM 1951) provided mollusc faunas which are comparable to the 'Bucher Schneckenmergel' (see 3.1.1). Based on its faunal composition a Tiglian age is probable for the 'Staudenplattenschotter'. Regarding the relationship with the 'Zusamplattenschotter' (see 3.2.3) the 'Staudenplattenschotter' may be assigned to an older part of Tiglian.

\subsection{2 Ältester Periglazialschotter ['Oldest Periglacial Gravel']}

\section{First description and current application.}

The term 'Alltester Periglazialschotter' is used by Dopplen (2003) as collective name for gravel deposits which occur locally below the 'Höhere Ältere Deckenschotter'. The socalled 'Ottobeurer Schotter' (EBERL 1930), the 'Liegendfazies' (SINN 1972; LÖSCHER 1976), and the 'Urdonauschotter' (gravel of the proto-Danube; Scheuenpflug 1971, VILLINGER 2003) are considered as parts of this unit. The 'Älteste Periglazialschotter' are assumed to be deposited as channel fills aside of glacial runoff.

\section{Type region and occurrence.}

So far 'Älteste Periglazialschotter' are verified only in the western part of the Bavarian Alpine Foreland. The 'Ottobeurer Schotter' and the 'Liegend-' or 'MolassekristallinFazies' are to be found at the south-western Iller-Lech alluvial plain and the 'Zusamplatte', the 'Urdonauschotter' in the northern part of this area.

At present no permanent outcrops of the 'Ottobeurer Schotter' are available. Hence, we have to refer to the descriptions of EBERL (1930: 312), SINN (1972) and RöGNER \& Löscher (1993). The 'Liegendfazies' or 'Molassekristallinfazies' in the Iller-Mindel alluvial plain may still be investigated in the vast clay pit near Altenstadt/Untereichen. From here these deposits are described on top of sandy Molasse sediments by LösCHER (1976: 49). Another outcrop is the gravel pit west of Wettenhausen where superimposed glacio-fluvial 'Höherer Älterer Deckenschotter' could not be identified but may be masked by weathering.

The well-described gravel pit at the Kirchberg in Wörleschwang may serve as type locality of the 'Urdonauschotter’ (Löscher 1976: 14; BecKer-Haumann 2003: 158). The specific facies of the proto-Danube is exposed here temporarily in new gravel pits.

\section{Termination and lithology.}

The 'Ältester Periglazialschotter' mostly appears incised in sediments of the Upper Freshwater Molasse. The channel fill deposits are covered by 'Höhere Ältere Deckenschotter' in a facies dominated by Alpine carbonates. At some outcrops clods of marl are found at the base of this superimposed accumulation. Near Buch in-situ fine-grained flood deposits containing interglacial molluscs occurred in a comparable position (SCHRÖDER \& DEHM 1951).

Due to a different pebble composition the 'Älteste Periglazialschotter' can be distinguished from the covering 'Höhere Ältere Deckenschotter'. The 'Ottobeurer Schotter' and the 'Liegendfazies' are characterised by a higher amount of central-alpine crystalline components. They are regarded as deposits of periglacial streams with a catchment area in the conglomerate sequences of the Miocene alluvial fan of the Adelegg (SinN 1972; 'Molassekristallinfazies' cf. DOPPler 2003a). The 'Urdonauschotter' in contrast is primarily composed of pebbles derived from the Alb (Malm limestone) and sporadically also from the Black Forest (e. g. red granite; VILLINGER 2003). 


\section{Classification and correlation.}

Only the molluscs of the covering fluvial sediments, which are mostly preserved just as redeposited clods, enable a correlation with the Tiglian of north-western Europe (RÄHLE 1995; MÜNZING \& AKTAS 1984). Thus they give evidence for the minimum age of the underlying 'Allteste Periglazialschotter'. Generally just a relative classification older than the 'Donau'-aged covering 'Höhere Ältere Deckenschotter' is possible. Hence, a correlation with the 'Biber'-aged 'Älteste Deckenschotter' is feasible but not documented definitely. Apparently the 'Älteste Periglazialschotter' were deposited west of the 'Alteste Deckenschotter' of the proto-Iller and form the infill of a deeper incised discharge system.

\subsubsection{Höherer Älterer Deckenschotter ['Higher Older Cover Gravel']}

First description and current application.

The term 'Höherer Älterer Deckenschotter' is used for the first time by DOPPLER \& JERz (1995) describing the equivalents of the 'Zusamplattenschotter'. It is intended to distinguish an older part of the 'Älterer Deckenschotter' that occurs at a higher level in the type region near Memmingen from a younger part at a lower level. The first called 'Höherer Älterer Deckenschotter' - is classified as 'Donau'-aged. The latter - called 'Tieferer Älterer Deckenschotter" - is assumed to be of 'Günz' age (see 3.2.4). PENCK \& BRÜCKNER (1901-1909) and in many cases also EBERL (1930) assumed a 'Günz' age for the total of all 'Ältere Deckenschotter'. PENCK \& BRÜCKNER (1901-1909) interpreted the higher position of some occurrences of their "Alltere Deckenschotter' as a result of tectonic movements. EBERL (1930) disproved this view and introduced the new 'Donau' glacial to explain these circumstances (cf. 3.1.2).

In Baden-Württemberg deposits correlating with 'Zusamplattenschotter' are called 'Allteste Deckenschotter' like 'Biber'-aged gravels in Bavaria. Graul (1949) and his students (SINN 1972, LöSCHER 1976) use the term 'Unterer Deckschotter' for corresponding deposits and assign them later on to 'Donau'.

\section{Type region and occurrence.}

The Zusamplatte - without the north-western extensions of the 'Druisheimer' and the 'Wortelstettener Schotter' - is suggested as type region for the 'Höhere Ältere Deckenschotter'. It should be made clear that the locally underlying 'Liegendfazies' respectively 'Molassekristallinfazies' (see 3.2.2) has to be separated from the 'Höherer Älterer Deckenschotter'. The gravel pits Altenstadt/Untereichen and Kirchberg at Wörleschwang may be regarded as type localities of the 'Höhere Ältere Deckenschotter' revealing especially its lower boundary to the underlying 'Allteste Periglazialschotter'.

More occurrences of the 'Höherer Älterer Deckenschotter' in the Riß-Lech alluvial plain can be traced from the region of Memmingen along the Zusamplattenschotter to the 'Untere Deckschotter' of the Aindlinger Terrassentreppe. All this gravel deposits originate from the proto-Iller (SINN 1972). The isolated occurrence of the Stoffersberg near Landsberg/ Lech may represent an affluent originating from the Lech area. In the eastern Bavarian Alpine Foreland further accumulations of 'Höhere Ältere Deckenschotter' occur along the former river course of the Danube (recent mapping of SchellmanN) or along periglacial affluents (e. g. valley of the Paar, Doppler et al. 2002). They all show an elevated position above gravel deposits assumed to 'Günz'. Comparable evidence in the south-eastern Bavarian Alpine Foreland is still missing. Some gravel deposits on a higher level than 'Alltere Deckenschotter' but of assumed Pleistocene origin are described from the northern rim of the Hausruck and Kobernaußerwald (Upper Austria) in the foreland of the former Salzach glacier (e. g. 'Eichwaldschotter'; EBERs et al. 1966).

\section{Termination and lithology.}

'Höhere Ältere Deckenschotter' often are embedded more than $20 \mathrm{~m}$ deeper than the lowest 'Älteste Deckenschotter' ('Zusamplattenschotter' versus 'Staudenplattenschotter') and about $10 \mathrm{~m}$ higher than the bottom of the oldest accumulations attributed to the 'Tiefere Ältere Deckenschotter'.

The discovery of an interglacial mollusc fauna in the upper segment of the 'Zusamplattenschotter' near Lauterbrunn (RÄHLE 1995) implies that this widespread accumulation is probably composed of different sedimentary sequences of cold and warm phases of the 'Donau' age. However, no terrace flight is observable. That contradicts the view of ScHAEFER (1980) discerning an extensive number of terraces at the Zusamplatte. Moreover, it must be kept in mind that 'Älteste Periglazialschotter' and their covering fine-grained flood deposits (see 3.2.2) may occur not only below the 'Höhere Ältere Deckenschotter' but locally may reach to the surface.

Primarily in the southern areas where its remnants show a thickness of more than $5 \mathrm{~m}$ the 'Höherer Älterer Deckenschotter' is predominantly unweathered but in part contains brittle dolomite pebbles. A consolidation to Nagelfluh is possible and deep weathering cones may occur (e. g. 'Geologische Orgeln' at Bossarts south-west of Ottobeuren). The gravel distribution is less reduced by erosion than for 'Alteste Deckenschotter'. On widely preserved plateaus often covering strata of aeolian origin (loess loam) reach a thickness of more than $10 \mathrm{~m}$. They are usually subdivided by surfacewater gleyic palaeosols ('Pseudogley'). Below the last-interglacial soil these palaeosols are mostly amalgamated and do not approve a clear stratification.

\section{Classification and correlation.}

Biostratigraphical and magnetostratigraphical methods mostly can be applied in the covering strata (see 3.1.2; e. g. Uhlenberg) and result in minimum ages for the gravel deposits. Fauna is very rare, especially within the gravel deposits. The molluscs of Lauterbrunn are comparable with fauna collections from 'Älteste Deckenschotter' and other places of 'Höherer Älterer Deckenschotter' of the Iller-Lech alluvial plain. According to RÄHLE (1995) all these faunae correlate with the Tiglian.

HäusElmanN et al. (2007) presented a first numeric age for the 'Höhere Ältere Deckenschotter' of the 'Böhener Feld' by cosmogenic nuclides (burial age dating). This method is in an early stage so that the resulting age of $2.35+1.08 /-0.88$ Ma has to be considered with caution. 'Günz' age was origi- 
nally supposed by PENCK \& BRÜCKNER (1901-1909) for the 'Böhener Feld' and adopted by HäusELmanN et al. (2007). But since LösCHER (1976) these conglomerates ('Nagelfluh') sampled at Wolfertschwenden are mostly assumed to be of 'Donau' age.

\subsubsection{Tieferer Älterer Deckenschotter ['Lower Older Cover Gravel']}

\section{First description and current application.}

Investigations by PENCK (1899) at the Falkensporn (south of Memmingen) led to a disjunction of the 'Deckenschotter' in two autonomous accumulations separated chronologically into 'ältere' and 'jüngere' respectively 'obere' and 'untere Deckenschotter'. The 'Alltere Deckenschotter' he assigned to the fourth to last glacial called 'Günz'. EBERL (1930), Schaefer (1957), and Löscher (1976) carried out more detailed subdivisions of the 'Ältere Deckenschotter'. Only small parts of the formerly wide-spread gravel deposits remained to be of 'Günz' age. For these parts the term 'Tieferer Älterer Deckenschotter' was introduced by DOPPLER \& JERZ (1995) in order to characterise the terrace morphological position between the 'Donau'-aged 'Höhere Ältere Deckenschotter' and the 'Mindel'-aged 'Jüngere Deckenschotter'. In the reverse conclusion 'Günz' is defined by the 'Tieferer Älterer Deckenschotter'. This is not satisfying but at that time without alternative.

\section{Type region and occurrence.}

Corresponding deposits are scarce on the southern IllerLech alluvial plain. Here for a trusted integration to the stratigraphic system a type location should be found for the 'Tiefere Ältere Deckenschotter'. Not until the northwestern parts of the Iller-Lech alluvial plain they appear as 'Zwischenterrassenschotter' (Löscher 1976). But their classification into the 'Günz' by Doppler (2003a) as a continuation of the 'Zeiler Schotter' (SCHREINER \& EBEL 1981) is controversial. Löscher (1976) assigned the 'Zwischenterrassenschotter to the 'Donau'.

On the southern Iller-Lech alluvial plain the 'Tiefere Ältere Deckenschotter' is represented by some resticted occurrences of gravel deposits (RöGNER 2004). However, their classification is not always undisputable. For instance recent mapping did not yield a difference of the 'Zadels-Stefansrieder Schotter' of assumed 'Günz' age and the 'Donau'-aged 'Böhener Schotter' (pers. commun. B. LEMPE). One of the reasons for the limited distribution of 'Tiefere Ältere Deckenschotter' may be the reorientation in the main discharge direction of the glacial runoff of the former Rhine and Iller glacier. The flew direction moved from northeast during 'Biber' and 'Donau' near to north during the 'Günz'.

More outcrops of the 'Tieferer Älterer Deckenschotter' exist in the rest of the Alpine Foreland. They occur in the area of the 'Münchner Schotterebene' in a normal-stratigraphical succession below 'Mindel'-aged 'Jüngerer Deckenschotter' (e. g. 'Klettergarten Baierbrunn', Jerz 1993). According to their position they mostly are exposed just along deeply incised valleys like that of the Isar. In the foreland of the former Inn glacier they build up the 'Rattenkirchener Schotterfeld' (KöNIG 1979: 47). In the Bavarian part of the former Salzach-glacier foreland an occurrence at the Eschelberg west of Burghausen is to be mentioned (EICHLER \& SinN 1974). At the Hechenberg more close to Burghausen and around Altenmarkt at the river Alz gravel deposits probably were accumulated during the advance of the 'Günz'-aged glacier (Doppler 1980: 152-159). It is not possible to correlate these basin internal occurrences directly with terrace stratigraphical units of the foreland. Also along the former river course of the Danube as well as in autochthonous tributaries like the valley of the Paar corresponding levels of gravel-bearing terraces are verified (Schellmann 1990; Doppler et al. 2002).

The 'Fagotienschotter' (named after the gastropod Fagotia acicularis) west of Moosburg between the valleys of Isar and Amper was deposited during a warm period as demonstrated by the included molluscs. The gravel deposits are situated on the level of the 'Hochterrasse' of the Isar but biostratigraphically they should be older than the Northern German 'Elsterian' according to KovAndA (2006). They may represent a warm phase during the deposition of the 'Tiefere Ältere Deckenschotter' or an interglacial gravel deposit of the 'Günz/Mindel' which so far was not regarded in the Bavarian Alpine Foreland.

\section{Termination and lithology.}

Compared to older deposits the base of the 'Tiefere Altere Deckenschotter' on the Iller-Lech alluvial plain generally is more clearly incised. The base of the 'Höhere Ältere Deckenschotter' on the northern Iller-Lech alluvial plain is still located about $10 \mathrm{~m}$ higher. The base of the 'Jüngere Deckenschotter' is situated considerably about $20 \mathrm{~m}$ lower in the area of Ulm.

In contrast to the 'Höherer Älterer Deckenschotter' the 'Tieferer Älterer Deckenschotter' is not underlain by channel fills rich in crystalline Molasse pebbles. Generally, the 'Tiefere Ältere Deckenschotter' are characterised by a composition dominated by carbonate pebbles. Crystalline pebbles are hardly to find. In contrast to this in the area of the 'Zwischenterrassenschotter' in the northern Riß-Lech alluvial plain the deposits are typified by relic pebbles and the absence of carbonate material. It is not finally assured if this results form reworking of older weathered gravels (LöSCHER 1976) or in-situ weathering (DOPPLER 2003b). The periglacial gravel deposits of the Paar valley (Dopplen et al. 2002), but also the glacio-fluvial gravel deposits of the Eschelberg west of Burghausen (GRIMM et al. 1979) show completely aberrant spectra dominated by Quartz which is a result of reworking Molasse gravel.

Like all of the 'Deckenschotter' the 'Tiefere Ältere Deckenschotter' show calcitic conglomerations throughout the whole accumulations and not only near the valley rims. At some places the conglomerates ('Nagelfluh') are interspersed with partly very broad and deep weathering structures similar to the narrower geologic pipes of the 'Jüngere Deckenschotter' ('Geologische Orgeln'; e. g. 'Klettergarten Baierbrunn').

\section{Classification and correlations.}

So far the 'Tieferer Älterer Deckenschotter' is not dated by numeric or biostratigraphical methods. So, only the relative stratigraphical position can be determined based 
on the terrace sequences and covering strata (e. g. Bibus 1995). A magnetostratigraphical analysis of fine-grained sediments in related moraine deposits (BIBUs et al. 1996) or in loess loam strata was tried (STRATTNER \& Rolf 1995; DOPPLER \& JERZ 1995). The results are ambiguous. Reversed polarity is yielded for the moraine deposits and a normal polarity for loess strata of assumed similar age. Thus, these results are not sufficient to support extensive correlations to sequences outside the distributional area.

\subsubsection{Jüngerer Deckenschotter ['Younger Cover Gravel']}

\section{First description and current application.}

In the fundamental chapters and profiles of PENCK \& BRÜCKNER (1901-1909: 31, 48) the term 'Jüngerer Deckenschotter' or 'Unterer Deckenschotter' is applied for the Grönenbacher Feld near Memmingen. However 'Deckenschotter' are sub-divided already by PENCK (1899). Additionally PENCK \& BRÜCKNER (1901-1909: 110) refer to equivalent terrace deposits along the Mindel valley and at the Rothwaldfeld northwest of Schongau.

So far in Bavaria the term 'Jüngerer Deckenschotter' is used to indicate gravel deposits of the 'Mindel' glacial. Compared to PencK \& BRÜCKner (1901-1909) only minor changes have been made by discerning accumulations of 'Jüngere Deckenschotter' with different age. An older gravel accumulation assigned as 'Haslachschotter' in the Upper Swabian Rot valley is separated from a younger ('Tannheimer Schotter' = 'Mindel' sensu stricto). The 'Haslachschotter' is eponymous to the Haslach glaciation (SCHREINER \& Ebel 1981; see 3.1.5).

\section{Type regions and occurrences.}

The type region for the 'Jüngere Deckenschotter' preferably has to be located in the Iller-Lech alluvial plain. PENCK \& BRÜCKNER (1901-1909: 28, 31, Fig. 3, 4) describe the Grönenbacher Feld as a typical occurrence of the 'Jüngere Deckenschotter'. An interglacial subdivision of this accumulation was recently suggested by BECKER-HAUMANN (2005: 229) but is not widely accepted. Other references concern the valley of the river Mindel ('Kirchheim-Burgauer Schotter') where glacial runoff is documented from the 'Altmoräne' (older moraines) of the Holzheuer Höhe north of Obergünzburg down to the Danube (PENCK \& BRÜCKNER 1901-1909: $54,110)$. The area of Upper Swabia will be of special importance for definition because of the clear subdivision of the 'Jüngere Deckenschotter' into two terrace deposits, the 'Haslachschotter' and the 'Tannheimer Schotter'. The two accumulations are separated by the soil remnants of a warm phase. On the other hand at the 'Klettergarten Baierbrunn' (climbing park) the 'Jüngere Deckenschotter' is embedded between gravel deposits of 'Günz' and 'Riß' age in a normal stratigraphical succession separated by relics of interglacial soils. However, a decision on formal type localities is not yet made.

'Jüngerer Deckenschotter' also frequently occurs in the Alpine Foreland apart from the areas already mentioned. A part of the 'Hochterrasse' in the Günz valley must be reckoned to the 'Jüngere Deckenschotter' based on the higher position of the gravel base and the habitus of the covering strata (unpubl. borehole data; DopPLER 1985; RöGNER et al. 1988; BiBus 1995). Further occurrences are found in the Rothwaldfeld northwest of Schongau between Wertach and Lech, in the northern Inn glacier foreland, and in the Dungau along the Danube southeast of Regensburg. Conglomerates crossing over in tills of assumed 'Mindel' age are known from most of the glacier lobes of Southern Bavaria and often are attributed to the 'Jüngere Deckenschotter'. Corresponding occurrences of gravel deposits of the ice-advance ('Vorstoßschotter') are widespread for instance at the Bavarian western flank of the Salzach glacier.

Morphologically many of the 'Jüngere Deckenschotter' can be coupled with parts of the 'Altmoräne' (older moraines) forming a 'Gaziale Serie'.

\section{Termination and lithology.}

Outside the moraine area the base of the 'Jüngerer Deckenschotter' is situated at about $10 \mathrm{~m}$ below the base of the 'Tieferer Älterer Deckenschotter' and more than $10 \mathrm{~m}$ above the base of the 'Riß'-aged 'Hochterrasse'.

Lithologically the 'Mindel'-aged 'Jüngerer Deckenschotter' generally is typified by a huge amount of carbonate pebbles of Alpine origin. However, it shows already an increasing content of crystalline components in the Rhine and Inn glacier area derived from their catchment area within the Central Alps. In contrast the Salzach glacier and the Isar-Loisach glacier, connected by transfluent pathways with the Central Alps too, show a significant increase of crystalline components at first during the 'Riß' glacial.

The 'Jüngerer Deckenschotter' is mostly conglomerated and shows intensive weathering structures at its surface. In some places 'Geologische Orgeln' (geologic pipes) could be found penetrating up to $10 \mathrm{~m}$ into the gravel deposits. These features often form spectacular narrow funnels (e. g. former quarry of Oberschroffen southeast of Altötting; see www. lfu.bayern.de/geologie/fachinformationen/geotope_schoensten/oberbayern/82). Partly these pipes are decapitated by erosion and contain either the original filling of weathered loamy gravel or the former residue has already flown out and the pipes are completely empty.

\section{Classification and correlations.}

According to the terrace stratigraphy the 'Jüngere Deckenschotter' have a relative position between the higher elevated 'Tiefere Ältere Deckenschotter' the lower situated 'Hochterrasse'. 'Jüngerer Deckenschotter' can be distinguished from 'Hochterrasse' sometimes by a lower content of crystalline pebbles, a higher degree of conglomeration, a more intensive weathering or the development of at least one more palaeosol in the covering strata. So far no fossils suitable for a biostratigraphical interpretation have been found. The few available magneto-stratigraphical data are inconsistent. Reversed polarity in the Rhine-glacier area near Heiligenberg close to Pfullendorf (pers. commun. D. ELLWANGER) contradicts the normal polarity in the Salzachglacier area near Trostberg (STRATTNER \& RolF 1995; DOPPLER \& JERZ 1995).

Numeric datings were attempted by using cosmogenic nuclides or luminescence. A first burial-age for the 'Jüngerer Deckenschotter' of Bad Grönenbach by HäUSELMANN et al. (2007: 41) is given with $0.68+0.23 /-0.24 \mathrm{Ma}$. But as an output of a single measurement using a very new method this 
age seems not yet reliable. New IRSL-datings by KLASEN (2008) are still inconsistent and will be currently reviewed.

\subsubsection{Hochterrasse ['Higher Terrace']}

First description.

In the valleys of the Alpine Foreland already PENCK (1882: 254, 290) differentiated between a lastglacial 'unterer Glazialschotter' (lower glacial gravel deposit) without a loess cover and a higher elevated 'oberer Glazialschotter' (upper glacial gravel deposit) that generally is covered by loess. PENCK (1882) used the term 'Hochterrasse' for the latter of both terrace levels and assigned its deposits later to the 'Glaziale Serie' of the 'Riß' (PENCK \& BRÜCKNER 1901-1909: 110). However, PENCK supposed a nonexisting linkage between an older moraine stage ('Doppelwall' = double ridge) and a younger terrace ('Untere Hochterrasse' or '13 m-terrace'). PENCK \& BRÜCKNER (1901-1909) knew about different levels of 'Hochterrasse' - plains near Memmingen and in the Riß valley but did not apply a more detailed subdivision of these terraces.

\section{Current application.}

Recently a probably threefold subdivision of the 'Riß' separated by warm phases is assumed (MIS 10 to MIS 6; see 3.1.7). As a consequence variations of the covering strata and the degree of weathering on the different terrace levels led to a partly re-evaluation of diverse stages of the 'Hochterrasse' and their gravel deposits (BIBus \& KösEL 1987, MiARA 1996). In several valleys a lower (younger) and an upper (older) 'Hochterrasse' can be distinguished morphologically. In the Danube valley near Straubing three 'Hochterrasse' levels are described by Schellmann et al. (2010: 121). An even more extensive classification is carried out by Bibus of Strahl (2000) in the valley of the Danube near Höchstädt. They assign an 'Oberste (topmost) Hochterrasse' to the fifth last cold period. By the means of the stratigraphic classification applied in this paper this would be 'Mindel' and hence this highly elevated accumulation will be regarded as 'Jüngerer Deckenschotter'. The gravel deposits of the less elevated 'Obere Hochterrasse' locally are separated in two superimposed accumulations. This subdivision was found near Höchstädt too (LEGER 1988; Bibus \& STRAHL 2000) and also in the Lech valley (Tillmanns et al. 1982; Aktas \& Frechen 1991; BeckerHaumann \& Frechen 1997). The two gravel accumulations in some places are separated by clods of marl at the base of the upper accumulation for once also a single pelitic layer in the intersection of both accumulations. These marls partly provide molluscs indicative for an interglacial interruption of the gravel deposition. At the valley of the Danube between Regensburg and Straubing the 'Obere Hochterrasse' but perhaps even the 'Jüngerer Deckenschotter' are underlain partly by gravel-bearing channel fills. At Regensburg-Harting this accumulation is covered by an interglacial peat (see 3.1.6; Hartinger Schichten after SCHELlMANN 1990).

\section{Type regions and occurrences.}

Extensive investigations on gravel deposits, weathering and covering strata of the 'Hochterrasse' (MIARA 1996,
Bibus \& KöSEL 1997) and the linkage to the type region of the 'Riß' argue to assign the gravel pits in the valley of the Riß near Baltringen in Württemberg as type locality for 'Obere' and 'Untere Hochterrasse'. The subdivision of the gravel deposits of the 'Obere Hochterrasse' in two separated accumulations is well-described from the gravel pit north of Münster on the 'Rainer Hochterrasse' (TILlmanns et al. 1982). In a quarry west of Höchstädt on the 'Dillinger Hochterrasse' reworked clods of marl but also in-situ sand and silt lenses could be observed. They at least in part include warm-temperate molluscs (LEGER 1988: 329; Fig. 71; Bibus \& STRAhl 2000). And even one of the currently accessible gravel pits near Bobingen may serve as type section after further investigations.

'Hochterrassen' are widespread also in the remaining Bavarian Alpine Foreland along the river valleys but also in already abandoned valleys. The following occurrences should be noted because of their differentiation or recent investigation:

(i) 'Hochterrassen' in the further stream course of the Danube between Neuburg and the Weltenburger Enge (Weltenburg gap; Fiebig \& Preusser 2003) and between Regensburg and Vilshofen (Kroemer 2007; SchellmanN 2010) which are separated into different levels. However, the classification of the lowest loess-covered terrace as 'Übergangsterrasse' (Transitional terrace) of 'Early Würm' age has to be taken into account here.

(ii) The different levels of the 'Hochterrasse' in the Salzach-glacier area (GRIMm et al. 1979; DopPler 2003b) with a significant lower 'Hochterrasse'.

The special characteristics of the 'Münchner Schotterebene' providing a normal stratigraphic gravel succession may be attributed to a neotectonic subsidence southwest of the 'Landshut-Neuöttinger Abbruch' (Landshut-Neuötting fault). However, a similar superposition by younger gravel deposits near the front of the connected moraines occurs in other places too, for instance in the Salzach-glacier area (see below). The usual terrace flight successions occur not until the so-called 'terrace-crossings' downstream.

The 'Fagotienschotter' west of Moosburg situated between the valleys of Isar and Amper was assigned morphologically to the 'Hochterrasse'. But due to its mollusc content it seems to be significantly older (KovandA 2006; see 3.2.4).

\section{Termination and lithology.}

The superposition of gravels of the 'Hochterrasse' by those of the 'Niederterrasse' or of the 'Jüngerer Deckenschotter' by gravels of the 'Hochterrasse' and the separation of the accumulations by remnants of fossil soils are very common in the 'Münchner Schotterebene' (fluvial plain of Munich). Similar conditions frequently occur in the area of the former Salzach glacier, for instance at the eastern riverside of the Salzach at Burghausen (STARNBERGER et al. 2008), south of Palling (EBERs et al. 1966) or near Haselreit/ Kienberg. At all of these sites 'Riß'-aged 'Hochterrasse' gravels are overlain by 'Würm'-aged 'Niederterrasse' gravels and separated by palaeosol relics. On the other hand downstream the Alz near the village Mankham/Tacherting geological pipes in the 'Jüngerer Deckenschotter' are cut by 'Hochterrasse' deposits (EBERs et al. 1966; Doppler 2003b). 
Apart from these conditions the base of the gravel deposits of the 'Hochterrasse' may be situated up to $10 \mathrm{~m}$ lower in comparison to the 'Jüngere Deckenschotter'. Even downstream in the valley of the Danube the terrace surfaces are situated at least a few meters higher than the 'Niederterrasse' or 'Übergangsterrasse'. However, as a result of extreme downcutting locally the base of the gravel deposits of the 'Hochterrasse' may occur below the base of younger accumulations.

The gravel deposits of the 'Hochterrasse' derived from melt water pathways connected with central Alpine glaciers (Rhine, Isar-Loisach, Inn-Chiemsee and Salzach glacier) often show a significantly higher amount of crystalline pebbles compared to the 'Jüngerer Deckenschotter'. A similar significant difference to the pebble content of the 'Niederterrasse' does not exist. Conglomeration is discontinuous but wide-spread and may be very intensive and enduring in marginal valley outcrops. In contrast to the 'Jüngerer Deckschotter' the 'Hochterrasse' deposits mostly show weathering cones smaller than $2 \mathrm{~m}$ instead of geological pipes. However, significantly deeper weathering pipes were recently described from the Hawanger Feld southwest of Memmingen (LEMPE 2008).

\section{Classification and correlations.}

Except of the cases of superposition the gravel deposits of the 'Hochterrasse' according to the terrace stratigraphy are situated between the higher positioned 'Jüngere Deckenschotter' and the lower positioned 'Niederterrasse' (resp. 'Übergangsterrasse'). Differences in the extent of soil development and the amount of palaeosols in the covering strata are used by BiBus (1995), MiARA (1996), and BiBus \& STRAHL (2000) to differentiate at least three accumulations of the 'Hochterrasse'.

There is a lack of finding places and even of appropriate fossil taxa for an accurate biostratigraphical classification. An exception may be the observed clods of marl and rarely occurring lenses of marl at the base of the younger accumulation of the upper 'Hochterrasse'. These marls contain partly interglacial and partly cold-phase molluscs (LEGER 1988: 329; Tillmanns et al. 1992; RÄHLE 1994). However, the material is mostly reworked and displaced and therefore provides only a limiting age for the embedding gravel deposits. RÄHLE (1994) assigns the interglacial fauna found in the clods of marl at Bobingen south of Augsburg and at Münster south of Rain older than Eemian.

Luminescence methods are available for numeric datings. Sand layers intercalating with gravels which were classified as 'Hochterrasse' so far and covering strata were sampled. Fiebig \& Preusser (2003) and Klasen (2008) yielded minimum ages of about $280 \mathrm{ka}$ up to $60 \mathrm{ka}$. Thus parts of the accumulations of the 'Rainer', the 'Neuburger' and the 'Ingolstädter Hochterrasse' seem to reach to the 'Early Würm' and therefore would have to be considered as 'Übergangsterrassen'. But the results of different luminescence methods are not always consistent (KLASEN 2008). As a consequence the Early Würm luminescence ages could not yet be evaluated generally for the classification of the lower stage of the 'Hochterrasse' as 'Übergangsterrasse' (Transitional terrace).

\subsection{7 Übergangsterrasse ['Transitional Terrace']}

\section{First description.}

The term 'Übergangsterrasse' leads back to SchellmanN (1990) and was introduced for a loess-covered terrace with a level between the typical 'Hochterrasse' and 'Niederterrasse' in the valleys of the lower Isar and the adjacent Danube. It is not yet proved how far the 'loess-covered Niederterrasse' (BRUNNACKER 1953a) and the 'Tiefere' or 'Jüngere Hochterrasse' (Miara 1996; Doppler 2003b) have to be considered as 'Übergangsterrasse'.

\section{Current application.}

The term 'Übergangsterrasse' is currently used by the Geological Survey of Bavaria for terraces which are assigned to the 'Early Würm' ('Frühwürm') due to their terrace morphological position, their weathering status, the development of their covering strata, as well as recent luminescence datings. Schellmann (2010: 11) divides the 'Übergangsterrasse' in two parts. However, definition and application of this comparatively new terrace stratigraphical unit has to be elaborated in the future.

\section{Type regions and occurrences.}

The area of the confluence of the rivers Isar and Danube and the Danube valley between Straubing and Osterhofen may serve as type area for the 'Übergangsterrasse', the gravel pit west of the Natternberg between Stauffendorf and Fehmbach as type locality (KROEMER et al. 2007). In this region the first description was carried out and dating results are already available (SchELLMANN 1990, 2010). Furthermore, similar occurrences are outcropping upstream the Danube valley between Ingolstadt and Neuburg and maybe in the 'Hochterrasse' of Rain (FIEBIG \& Preusser 2003) if dating results will be confirmed.

\section{Termination and lithology.}

The gravel deposits of the 'Übergangsterrasse' may be distinguished from older gravel deposits of the 'Hochterrasse' and younger deposits of the 'Niederterrasse' by their morphological position, the missing weathering of the 'Riß/ Würm' interglacial and by their reduced, only pleni- to late-glacial loess cover. The upper sections of the gravel deposits locally show a minor internal deformation (cryoturbation?) and reworked, transported, weathered pelitic material. The base of the covering pleniglacial loess is typified by laminae of sand ('sand-stripes'). Locally, the covering loess may be altered completely by the Late Glacial to Holocene soil formation that continues into the underlying gravel deposit.

The known thickness of the gravel deposits of the 'Übergangsterrasse' varies between 5 and $10 \mathrm{~m}$. The 'Übergangsterrassen' are unconformably underlain by the Molasse and/or older Pleistocene deposits (mostly gravel of 'Riß'age). The upper boundary to the covering strata (wash-out deposits or loess) is considered as hiatus too.

\section{Classification and correlations.}

The relative stratigraphical position of the 'Übergangsterrasse' is between the lowest 'Hochterrasse' and the highest 'Niederterrasse'. However, the actual position of the surface 
is located closer to the 'Niederterrasse'. The assignment to the 'Frühwürm' ('Early Würm' = Lower and Middle Würm) is based on the absence of a 'Riß/Würm' soil formation as well as of covering strata of 'Early Würm' age.

First numeric OSL-datings of different occurrences which so far were assigned to the 'Hochterrasse' resulted in ages between 90 and $25 \mathrm{ka}$. A sand sheet in the gravels at the suggested type locality near Stauffendorf yielded ages of 36-30 and 23-19 ka at the base of the superimposed loess (Kroemer 2010). According to the OSL-datings of 70-90 ka by Fiebig \& Preusser (2003) for the 'Neuburger' and parts of the 'Rainer Hochterrasse' as well as the 'Ingolstädter Hochterrasse' (accumulated by the 'Schutter-Danube') a future classification as 'Übergangsterrasse' seems likely. The change of the stream course of the 'Altmühl-Danube' firstly to the Schutter valley and following into the current Danube valley has to be rearranged from the end of the 'Riß' glacial into the 'Early Würm' in this case.

\subsubsection{Niederterrasse [,Lower Terrace']}

\section{First description.}

The term 'Niederterrasse' originates from PENCK (1884: 39) and was formalised by PENCK \& BRÜCKNER (1901-1909: 28, 48). But already Penck (1882) discerned these terrace level (see 3.2.6). The term 'Niederterrasse' was first used to denominate the terrace gravel of the 'Memminger Trockental' (dry valley) deriving from the 'Jungendmoräne' (younger terminal moraine).

\section{Current application.}

The current use of the term 'Niederterrasse' has changed in part. Gravel beds formed by melt water of the 'Late Würm' are separated as 'Spätglazialterrasse' (Late Glacial Terrace), so that the term 'Niederterrasse' is limited to accumulations of the Würm Pleniglacial now. However, some authors (Schellmann 1990, Feldmann 1990) continue to use 'Niederterrasse' for all of the pleniglacial and late-glacial gravel deposits .

In the area proximal to the moraines a differentiation of the 'Niederterrasse' (sensu stricto) into several sub-units attributed to single moraine stands is possible:

(i) 'Niederterrasse 0' (advanced younger terminal moraine $=$ super-maximal stand)

(ii) 'Niederterrasse 1' resp. 'Hauptniederterrasse' (external younger terminal moraine correlating with the Last Glacial Maximum (LGM)

(iii) 'Niederterrasse 2' (intermediate stand of the 'middle' younger terminal moraine)

(iv) 'Niederterrasse 3' (internal younger terminal moraine)

Type regions and occurrences.

As an original type location the 'Memminger Trockental' (PENCK \& BRÜCKNER 1901-1909) has to be mentioned. But a transfer to the Isar or Inn glacier foreland appears reasonable. Here a complete differentiation into sub-units associated with terminal moraine ridge systems is given and first datings are available (Feldmann 1994, 1998; Megies 2006).

Comparable gravel beds of the 'Niederterrasse' exist along all the rivers of the Alpine Foreland which drained melt water during the pleniglacial 'Würm'. Apart from the rivers Isar and Inn, the valley of the Lech contains an exceptionally well developed terrace sequence that has been investigated in detail (SCHREIBER 1985, currently mapped by SCHELLMANN and students).

\section{Termination and lithology.}

The definition of the 'Niederterrasse' by the connection to pleniglacial moraine stages would actually require the discrimination of earlier underlying gravel deposits of the advancing glacier. However, the possibility of tracing the corresponding boundary along the melt water deposits into the glacier foreland is very limited (see SCHREIBER 1985; DreEsBACH 1986). So the gravel beds of the advancing phase are just separated as long as a till cover of the same depositional cycle is obvious. Downstream from the outermost moraine stand these early melt water deposits are usually integrated to the 'Niederterrasse'.

Regarding this kind of sequence the lower boundary of the corresponding gravels is mostly developed as a clear hiatus to the underlying Molasse sediments. But particularly in the proximate glacier foreland a normal stratigraphical overlap on older Pleistocene sediments may also be observed (see 3.2.6).

The thickness of the deposits of the 'Niederterrasse' averages between a few and several tens of meters. In the areas of ice-proximal sandur plains accumulations may exceed $50 \mathrm{~m}$ or more. However a share in these thick accumulations by gravels of the ice-advance or even older deposits cannot always be excluded.

Due to the position at the surface the uppermost part of nearly all of the 'Niederterrassen' is affected by soil formation. However, locally the 'Niederterrassen' are overlain by younger sediments like aeolian drift sand, in rare cases also loess (c. f. 'Übergangsterrasse'), alluvial fans, colluvial soils, and swamp and bog-lime deposits ('Wiesenkalk', 'Alm').

The 'Niederterrasse' in former melt water valleys primarily consists of gravel deposits always containing variable amounts of carbonate pebbles. In contrast gravel accumulations corresponding to periglacial, autochthonous tributaries coeval with 'Niederterrasse' contain material from the local catchment areas. They are generally free of carbonate material. Typically the melt water deposits consist of gravel with a variable sand content. In a proximal position to the moraines higher percentages of boulders and silt may be observed but this material quickly decreases downstream. The gravel was deposited by braided rivers and shows vertical bar aggradation ('Vertikalschotter' sensu SCHIRMER 1983). Occasionally the gravel is covered by thin blankets $(<1 \mathrm{~m})$ of fine-grained fluvial deposits. Near the valley rims some fine-grained sediment may occur as reworked material from nearby slopes.

Depending on the crystalline content brown earth (cambisol, 'Braunerde') or argilic brown earth (luvisol, lessivé, 'Parabraunerde') are developed on top of the 'Niederterrasse'. They may range from a few decimetres thickness up to $1 \mathrm{~m}$. The soil formation penetrates the fresh gravel deposit just rudimentally with very short fingerlike cones. At dry places the soils also may be red-coloured while at high water tables hydromorphic soils are formed, especially half-bog deposits (so-called 'Pechanmoor' after BRUNNACKer 1959; Kroemer 2010). Where ground water 
occurs as planar outlet peat and bog-lime have formed (e. g. Erdinger and Dachauer Moos).

\section{Classification and correlations.}

The identification of the 'Niederterrasse' in the sense of a 'Glaziale Serie' is based on the geomorphological connection to terminal moraine stages of the 'Würm pleniglacial' and on the relative terrace stratigraphical position between the loess-covered 'Hochterrasse' (or 'Übergangsterrasse') and the terraces of the Late Glacial.

Numeric ages between 25 and 17 ka BP for the deposits of the 'Niederterrasse' were determined using radiocarbon datings on mammoth tooth (GEYH \& SCHREINER 1984) as well as OSL-datings (Fiebig \& Preusser 2003, Megies 2006). Maximum and minimum ages may be deduced from underlying and overlying sediments. For example the loess-covered 'Niederterrasse' on the eastern bank of the river Salzach (Austria) opposite of Burghausen (Traub \& Jerz 1976; STARNBERGER et al. 2008) yielded radiocarbon and OSL ages for underlying loess strata of $21.7 \pm 0.25 \mathrm{ka} \mathrm{BP}(25.92-25.04 \mathrm{ka}$ cal. BP) respectively $19.9-21.5 \mathrm{ka}$.

\subsubsection{Spätglazialterrasse ['Late Glacial Terrace']}

\section{First description and current application.}

Terms like 'spätglaziale Terrasse' (terrace of the late glacial) or 'spätglazialer Schotter' (gravel of the late glacial) are used yet in former publications (e. g. KoEHnE \& NikLAs 1916). But it is not clear who at what time formed the term 'Spätglazialterrasse'. It was used in diploma theses of the 1970s at the Munich University (summarised by GRIMM et al. 1979) and finally documented in Jerz (1993). For the Geological Map of Bavaria the term 'Spätglazialterrasse' is applied for melt water and gravel deposits of the 'Spätwürm' (late Upper Würm) which is the period after the ice retreat from the internal terminal moraine (see 3.1.9). Other authors (Schellmann 1990, FELDMANN 1990) call the corresponding terraces and their deposits still 'Niederterrasse'. Two different levels may be frequently distinguished: 'Spätglazialterrasse 1' and '2' (respectively 'NT2' and 'NT3' after SCHELLMANN 1990).

\section{Type regions and occurrences.}

The Danube valley near Straubing where a widespread bisection of the 'Spätglazialterrasse' is confirmed by current datings (SCHELLMANN 2010) may serve as a type region for the 'Spätglazialterrasse'. Deposits of the 'Spätglazialterrasse' also occur along further river courses of the Alpine Foreland like the valleys of the Inn downstream of Kiefersfelden (Megies 2006), the Lech (SchreIBER 1985), the Isar between Freising and Deggendorf (Feldmann 1990, SchellmanN 1990), and the Danube between Dillingen and Donauwörth (e. g. Kleinschnitz \& Kroemer 2003) or from Regensburg to Pleinting (Schellmann 1990; Buch 1988).

\section{Termination and lithology.}

Where river courses changed after the 'Würm Pleniglacial' the base of the deposits of the 'Spätglazialterrasse' may be incised into Molasse sediments or accumulations older than 'Würm' forming a significant hiatus. But in most cases Late Glacial deposits follow directly on top of the grav- els of the 'Niederterrasse' sometimes just identifiable by a basal concentration of coarse boulders. Inside the tongue basins of the glaciers and the Alpine valleys the gravels of the 'Spätglazialterrasse' are underlain also by glacial till or glacio-lacustrine sediment.

The gravels of the 'Spätglazialterrasse' do not differ significantly from the gravels of the 'Niederterrasse' of corresponding catchments. They mostly show also vertical bar aggradation ('Vertikalschotter' sensu ScHIRMER 1983). But locally first tendencies to meandering features are visible, for example at the mouth of the Isar (KROEMER et al. 2007). Usually the thickness of the gravels varies between a few and several meters while a maximum of more than $10 \mathrm{~m}$ is occasionally reached.

Extreme thickness of overbank sediments is observed in the Danube valley, upstream of the confluence with the Isar (Kroemer et al. 2007, Kroemer 2010). On top of the Late Glacial gravel up to $3 \mathrm{~m}$ thick silty flood deposits occur which are locally underlain by up to $3 \mathrm{~m}$ thick deposits of fine sand. Typical soils on the top of the 'Spätglazialterrasse' are brown earths or argilic brown earths ('Parabraunerde'). But the degree of development is reduced compared to the 'Niederterrasse' (generally $<0.6 \mathrm{~m}$ ). The widespread occurrence of half-bog (so-called 'Pechanmoor') argues for at least temporary high water tables in many areas even after shifting of river courses and lowering of the river beds during the Holocene.

Separated by minor discontinuities the terrace deposits in part are covered by younger sediments like accumulations of alluvial fans, colluvial, and flood deposits. In contrast to the younger terrace the higher (older) level of the 'Spätglazialterrasse' (resp. 'NT2') may be covered by 'Flugsand' (drift sand). The lower (younger) level of the 'Spätglazialterrasse' was still in fluvial formation during the deposition of the drift sand in the final permafrost period of the Younger Dryas.

\section{Classification and correlations.}

Geomorphologically and due to their weathering status the 'Spätglazialterrasse' has to be classified between the youngest 'Niederterrasse' and oldest 'Postglazialterrasse'. A direct connection to late glacial terminal moraine ridges (from 'Stephanskirchener'- or 'Weilheimer Stand' to Egesen moraines, see Tab. 5) is rarely possible. The Late-glacial terrace formation is attributed rather to fluvial transformations than to sediment pulses caused by glacier activities. River-dynamic reactions are triggered by climate changes and the deglaciation of the glacier basins.

The 'Late Würm' and in consequence the 'Spätglazialterrassen' are defined after CHALINE \& JERZ (1984). A complete correlation to the 'Late Würm' according to palynological analyses (FirbAs 1949, 1952) is not expected (see 3.1.9).

Numeric radiocarbon datings in the area near Straubing (SCHELlmanN 2010: 28) assign the deposits of the 'Spätglazialterrasse 1' to the 'Allteste Dryas' (oldest Dryas) between 17 and $18 \mathrm{ka} \mathrm{BP}$ and some time before $14 \mathrm{ka} \mathrm{BP}$. The time of the deposition of the 'Spätglazialterrasse 2' spans between 14.0 and approximately $10.2 \mathrm{ka}$ BP (SCHELlmANN 2010: 35) and thus has continued until the end of the Younger Dryas. 


\subsubsection{Postglazialterrasse ['Post Glacial Terrace']}

First description and current application.

The first use of the term 'Postglazialterrasse' is in the dark like it was already told for the 'Spätglazialterrasse'. The term is used by Jerz \& SChmidt-Kaler (1999) and is almost synchronously introduced into the General Legend of the GK25 of Bavaria. According to the attribution to Lower, Middle or Younger Holocene ('Alt-, Mittel- and Jungholozän') there is a differentiation in 'Ältere' (Older), 'Mittlere' (Middle) and 'Jüngere Postglazialterrasse' (Younger Postglacial Terrace). However, just the areas influenced by flooding events of the Late Holocene and their corresponding deposits can be separated clearly. Therefore in many cases it is necessary to merge the 'Ältere' and the 'Mittlere Postglazialterrasse' and distinguish this combination from the 'Jüngere Postglazialterrasse', the Late Holocene floodplain stages including corresponding fine-grained fluvial deposits. Some authors just take a consecutive numbering to label the different Holocene terraces. So the terraces of the Isar and the Danube are subdivided as 'Holozänterrasse 1' to '7' ('H1'-'H7') by Schellmann (1990) and Feldmann (1990).

\section{Type regions and occurrences.}

Well developed and detailed investigated successions of the 'Postglazialterrasse' are available at different river courses of the Alpine Foreland. Due to the comprehensive classification, partly based on numeric datings, the Isar valley is suggested as type region (Feldmann 1990, SchellmanN 1990).

A comparable differentiation of the 'Postglazialterrasse' was recently dated by Megies (2006) at the lower river course of the Inn. Further detailed investigations were achieved lastly by Schreiber (1985) at the Lech, by SChellmann (1990), Buch (1988), JeRZ \& SCHMidt-Kaler (1995, 1999), Kleinschnitz \& Kroemer (2003) and by Kroemer et al. (2008) at different segments of the Danube. Knowledge is steadily increasing in the context of current geological mapping.

\section{Termination and lithology.}

Like the deposits of the 'Spätglazialterrasse' the gravels of the 'Postglazialterrasse' often are not incised to sediments of the Molasse. In many cases gravel deposits of the 'Niederterrasse' serve as substratum. The Holocene gravel beds with a clearly reduced thickness can be distinguished not only by a coarsening of the basal grain sizes but additionally by their different texture. Less frequently are typical warm-phase remnants and components of historic origin. 'Postglazialterrassen' predominantly evolved by reworking of older mostly 'Würm'-aged gravel and thus show only a minor modified composition.

The Holocene river accumulations were deposited in large parts by meandering rivers and show often a lateral bar aggradation ('Lateralschotter' sensu SCHIRMER 1983). Especially in the lower course of the rivers of the Northern Alpine Foreland or of the Danube hypsometrically less differentiated so-called in-line terraces ('Reihenterrassen' sensu SCHIRMER 1983) are formed. The single meander beds are divided into a central part predominantly composed of gravel and into the former river bed courses mostly filled with thick fine-grained sediment.

Also apart from these meander fills 'Postglazialterrassen' are frequently covered by fine-grained flood plain deposits of variable thickness. Due to generally high carbonate contents in the Northern Alpine Foreland they are often referred as 'Fluss-' or 'Auenmergel' (fluvial or floodplain marls). But for example on the gravels of the river Inn, which are very rich in crystalline components, the carbonate content of flood deposits is comparatively low. Overall the thickness of the Holocene river deposits (channel fill gravels and floodplain deposits) ranges from a few to several metres and rarely exceeds $10 \mathrm{~m}$.

According to their relatively young age the deposits of the 'Postglazialterrasse' are covered only by accumulations like colluvium, bog lime or peat in exceptional cases. The surfaces of the terraces generally show minor soil formation. Even the older ones do not reach a stadium more developed than rendzina or pararendzina, the younger Holocene floodplain deposits not more than virgin soils. At high water tables also peat occurs ('Pechanmoor').

\section{Classification and correlations.}

The immature soils characterise the deposits of the 'Postglazialterrasse' as accumulations of the youngest section of earth history. Geomorphologically they occur directly below the youngest 'Würm'-aged terrace ('Spätglazialterrasse') and reach down to the present river courses.

The classification is carried out by using different methods. Minimum ages for the gravel accumulations result from palynological investigations preferably on covering organic strata, from artefacts, and other archaeological indications. Dateable human products like brick or pottery remains found within the gravels however provide maximum ages for the 'Jüngere Postglazialterrasse' (Younger Postglacial Terrace).

Numeric ages reaching from $11.5 \mathrm{ka}$ cal. BP up to the present were determined on organic remains like wood or peat by using the radiocarbon method. Wood remains found in rivers of the Northern Alpine Foreland with sufficient amount of tree-ring structures can be analysed by the dendrochronological method which allows a chronology in a one-year-resolution for the whole Holocene (KROMER o BECKER 1993). OSL-datings on sand grains of the Holocene gravel deposits were successfully performed too.

\subsubsection{Jüngere Postglazialterrasse ['Younger Post Glacial Terrace']}

Due to their special characteristics some supplementary descriptions for the deposits of the 'Jüngere Postglazialterrasse' are given. The 'Jüngere Postglazialterrasse' is situated in the area of river-flood events during late prehistoric and historic times. Predominantly these terraces developed before the realisation of regulating activities which started for the large part during the $19^{\text {th }}$ century. 'Jüngere Postglazialterrassen' are generally characterised by 'Auenablagerungen' (fine-grained flood plain deposits). Their deposition was probably triggered by widespread forest clearing for agriculture and started already during the Bronze Age at the end of the Subboreal period. At the lower cours- 


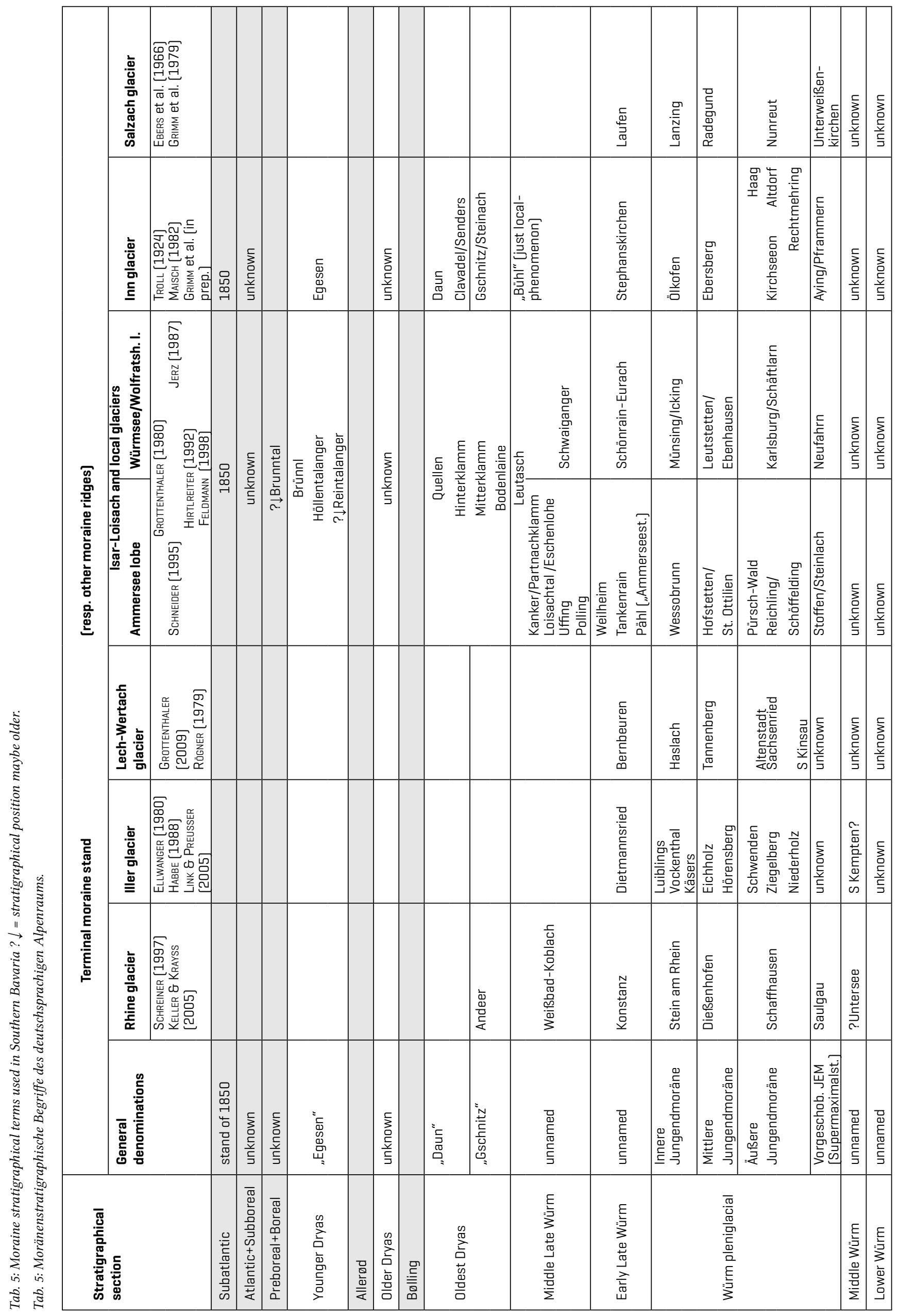




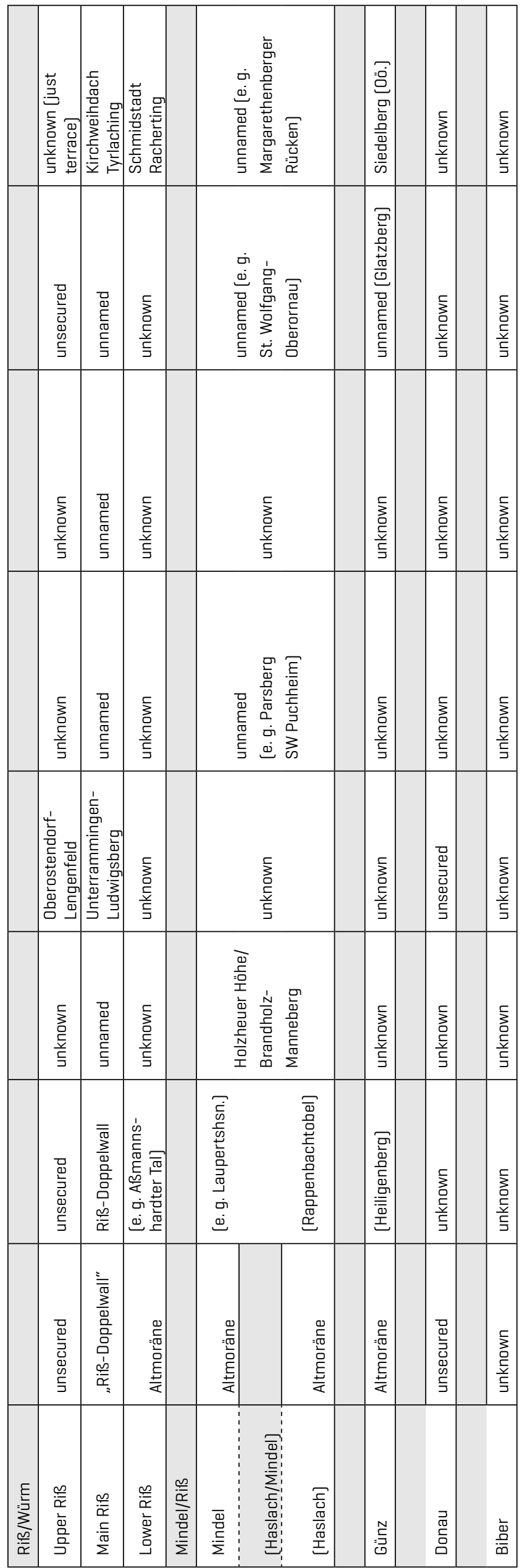

es of the rivers of the Alpine Foreland or at the Danube valley the terrace levels show only sparse hypsometric differentiation. So Late Holocene flood plain deposits reach far beyond the terraces of the Younger Holocene onto older terrace surfaces.

Concerning the 'Jüngere Postglazialterrasse' three generations are basically distinguished partly with further subdivisions (JeRZ \& SCHMIDT-KALER 1999; KLEINSCHNITZ o Kroemer 2003; Schellamann 2010). Their formation in most cases can be determined as Bronze to Roman period, mediaeval, and modern times. Numeric datings by using the radiocarbon method or dendrochronology yielded ages between $3 \mathrm{ka}$ BP until present. Beside the above mentioned methods also relics of human occupation or reworked artificial matter like ceramics can be applied for the classification. Historical maps like the primal cadastral mapping of the Bavarian Land Surveying Office serve as documents for the unregulated status of the rivers.

\subsection{Moraine stratigraphy for Southern Bavaria}

A continuous independent moraine stratigraphy is currently not available for Bavaria. On the Geological Map of Bavaria moraine deposits are distinguished by a combination of climate stratigraphical and petrogenetical terms. In addition specific moraine terminologies are used for the stratigraphical differentiation of moraines:

(i) a rough subdivision into 'Altmoräne' and 'Jungmoräne' (older and younger moraines) predominantly according to their morphological appearance,

(ii) a detailed supraregional applicable classification by discrimination of standardised terminal moraine stages during the 'Würm' and - less differentiated - during the 'Riß',

(iii) different classifications just related to one single glacier lobe using local names of terminal moraine ridge systems from 'Riß' to 'Holocene'.

All these classifications are largely limited to morphological landforms. A differentiation of distinct till generations deposited in superposition by different glacier advances of one cold stage is only exceptionally possible. It may be assumed just locally in single outcrops or in drillholes, so in the Rhine-glacier area of Baden-Wuerttemberg (e. g. SCHREINER 1996) or in the Bavarian Salzach-glacier area (GrImm et al. 1979: 111). In rare cases a fossil soil is passed on between superimposed moraine deposits supporting an interglacial hiatus.

\subsubsection{Geomorphological moraine classification}

A rough geomorphological classification of the moraine topography which enables an elementary stratigraphical relation follows the suggestion of PENCK \& BRÜCKNER (1901-1909: 125). They distinguish 'Jungmoräne' (younger moraine) characterised by a pronounced relief showing directly its glacigenous origin from 'Altmoräne' (older moraine) with more flattened and well smoothed forms. Enclosed hollow moulds (above all dead ice kettles) characteristic for the moraine topography of the last glacial epoch are rarely found in the area of the 'Altmoräne' 
for instance. This is due to periglacial processes, increasing periglacial loam covers and interglacial weathering. 'Altmoräne' of 'Riß', 'Mindel' and for once even 'Günz' age generally constitutes an outer belt around the 'Jungmoräne' (see Fig. 1).

\subsubsection{Classification by terminal moraine stages}

The classification based on terminal moraine stages (= 'stand'; 'stadium' is regarded to be chronologically) is based on the course of the moraine ridges, of peripheral melt water channels, and supplemented also by relictic dead ice features. Corresponding classifications essentially depend on the particular image of the shape of a glacier lobe, but are rarely supported by datings. For the well-preserved moraine stands of the Würm pleniglacial, the Late Würm and the Holocene a superordinate climate control is assumed. This is due to the uniformity of the terminal moraine sequences developed in the different glacier lobes of the Northern Alpine Foreland (e. g. Troll 1924). Thus, from the local classifications a supra-regional standardised classification was derived for the 'Würm pleniglacial' and rudimentary also for the 'Riß' (Tab. 5). For the older just sparsely preserved deposits of the 'Altmoräne' a corresponding subdivision is not feasible. The glaciers of the 'Late Würm' to Holocene, which retreated into the Alpine valleys are strongly affected by local factors, so that only a less reliable correlation is possible.

In his pioneering publication about the Inn-Chiemsee glacier Troll (1924) paid special attention to the recessional moraine stages ('Endmoränen-Stände') of the 'Würm'. His classification into the 'Kirchseeoner', the 'Ebersberger', the 'Olkofener' and the 'Stephanskirchener Stadium' is still in use. External of the 'Kirchseeoner'-terminal moraine stage remains of an older, more extensive but still 'Würm'-aged glacier advance exist, called the stage of 'Aying-Pframmern'. Partly those terminal moraine stages are subdivided into single echelons ('Staffeln'), for example the 'Haager', 'Altdorfer' and 'Rechtmehringer Staffel' of the 'Kirchseeoner Stand' (Troll 1924) or the recently performed differentiation of an 'Alt'- and a 'Jung-Ebersberger Stadium' by DARgA (2009). The exemplarily developed young moraine stages of the Inn glacier are considered as a kind of model-classification for all of Bavaria. Comparable local classifications exist for most of the Bavarian glacierlobes (Tab. 5).

A very detailed classification from 'Würm' to Holocene terminal moraines is presented from the Ammersee and partly the Würmsee lobe of the Isar-Loisach glacier. Lastly Hirtlreiter (1992), Schneider (1995) and Feldmann (1998) documented a large number of terminal moraine stages which are still visible between the 'Äußere Jungendmoräne' and the present day's glacier relics at the Wetterstein mountains (Tab. 5).

\section{Moraine classification from 'Würm' to Holocene.}

Terminal moraine stages of the early 'Würm' as they are verified in Switzerland (Preusser 2004) are not documented clearly in the Bavarian Alpine Foreland up to now. However Link \& Preusser (2005) specified indirectly a piedmont glaciation approximately 60 ka ago (MIS 4) in the basin of Kempten at the area of the Iller glacier.

The correlation of the terminal moraine stages of the Pleni-, Late- and Post-glacial of the 'Würm' is predominantly tentative (HABBE 1988: 183, Fig. 4). Concerning the terminal moraine stages of the 'Würm' pleniglacial the supra-regional classification distinguishes an 'Äußere Jungendmoräne' (external younger terminal moraine; e. g. 'Kirchseeoner Stand' of the Inn-glacier), a 'Mittlere Jungendmoräne' (middle; e. g. 'Ebersberger Stand') and an 'Innere Jungendmoräne' (internal; e. g. 'Ölkofener Stand'). The conceptual discrimination of 'Äußere'- and 'Innere Jungendmoräne' was firstly performed by Schmidt (1911) in the Rhine-glacier area. The 'Äußere Jungendmoräne' marks the external 'Würm'aged, largely continuous terminal moraine stage which is often shaped as a double-ridge. The 'Innere Jungendmoräne' mostly rests on the edge of the tongue basins. The origin of the 'Innere Jungendmoräne' by some authors is attributed to a glacier readvance after an oscillation of elusive amplitude. According to ELLWANGER et al. (2003) a change of the glacial mechanics from a 'cold' to a 'warm based glacier' took place with this readvance and even the glacier basins should not have been excavated before.

The term 'Mittlere Jungendmoräne' was introduced into the Bavarian geological legend for the widespread ridge structures and ice-decay landforms between the 'Äußere' and 'Innere Jungendmoräne'. They are mostly displayed as an independent terminal moraine stage, even though terminal moraine ridges are not predominantly. External to the 'Äußere Jungendmoräne' locally further moraine hills of probably Würm-pleniglacial age occur. They are denominated as 'vorgeschobene Jungendmoräne' (advanced younger terminal moraine) respectively 'Super-' or 'Supramaximalstand' (e. g. 'Ayinger Stand' of the Inn glacier). The latter two terms were introduced in the Rhine-glacier area too by GERMAn \& MADER (1976). The first is used in Bavaria (e. g. Troll 1924: 32, Fig. 2; EBers et al. 1966: 121).

Just local denominations are available for the terminal moraine stages of the 'Late Würm' when the ice had retreated from the 'Innere Jungendmoräne' and for the Holocene terminal moraines. The closely investigated terminal moraine stages of the Inn glacier and its tributaries in Austria (PAtzelt 1980; MAIsch 1982) may still be used as a master classification for Bavaria too.

A mostly indistinct moraine stage during Late-glacial ice retreat - still attributed by some authors to the pleniglacial (see 3.1.9) - displays the 'Stephanskirchener Stand' of the Inn glacier (firstly mentioned by TrOLL 1924) as well as its equivalents at other glacier areas of the Alpine Foreland. This moraine stage generally crests the outer rim of the central glacier basins. A younger superordinate moraine stage during the ice retreat was already described by PENCK \& BrÜCKNER (1901-1909: Fig. 60) in the Inn valley as 'Bühl-Stadium'. Reitner (2007) however revealed that the corresponding landforms are to explain by local interactions of the Inn glacier with tributary glaciers in the area south of Kufstein/Austria. That means 'Bühl' is not a climate controlled stage comparable among different glacier areas. Further superordinate Late-glacial stages which are supposed to have a climatic trigger are those of 'Gschnitz', 'Daun' and 'Egesen'. The latter is commonly connected to the last climate deterioration of the 'Late Würm', the 
'Younger Dryas'. For the previous terminal stages the correlation to definable cold phases during the Late glacial is not verified so far.

Holocene glacier stages in the catchment of the former Inn glacier are described from the Central Alps (MAYR \& Heuberger 1968; Patzelt \& Bortenschlager 1978; MAISCH 1982). But a reliable correlation to the few Holocene glaciers of the northern side of the Bavarian Alps will hardly be possible. The same is also true for their recessional moraine stages of the 'Late Würm'. So far only local classifications concerning single glacier tongues are available (last mentioned in HirTLREITER 1992). Only the outermost terminal moraines of the so-called 'Little Ice Age' (14 $4^{\text {th }}$ to mid- $19^{\text {th }}$ century), the stages of 1850 , give better opportunities for reconstruction by using historical sources.

For a comparative classification and correlation of terminal moraine stages different methods are used. These are connections by shared melt water outflows, the general position in the morphological sequence of the glacier lobes or calculations of the snow line. The last one was applied particularly for the younger, inner-alpine stages.

So far numeric ages for moraine stratigraphical units are very rare. Moraines generally lack in organic material useable for radiocarbon datings. Age determinations on sparse mammoth teeth are restricted to the Rhine-glacier area outside of Bavaria. Data are summarized in KeLLER o Krayss (1998). The opportunities to detect buried or reworked wood remains in Holocene moraines are more promising. But this approach has its limitation as well. So the classification of the terminal moraine stages at the origin of the Loisach-glacier by HirTLREITER (1992) is based exclusively on snow line calculations and cannot be supported by numeric ages. Applying the relative new dating method of boulders via cosmogenic isotopes one has to consider disruptions caused by the intensive human occupation in the Alpine Foreland. First results were presented by REuTHER (2007) and Ivy-Ochs et al. (2008) for the area of the Isar-Loisach and the Inn piedmont glaciers. Exposition ages determined on large erratic boulders cover a broad period between 10.3 and 38.9 ka (Ivy-OcHs et al. 2008: 565).

\section{Moraine classification of the 'Riß'.}

A detailed classification into terminal moraine stages comparable to the 'Würm' and with the objective of supraregional relevance just exists for the 'Riß' age. According to the morphologically less concise circumstances this classification shows some major uncertainties and so far analogies are evident only between the areas of the Rhine and the Salzach glacier enframing the Bavarian Alpine Foreland. The classification of the Rhine glacier by its conceptional terms of 'Zungen-Riß' ('tongue Riß'), 'DoppelwallRiß' ('double ridge Riß') and the moraines of the 'JungRiß' ('younger Riß') denotes for supra-regional applicability. However, terminal moraine stages of the 'Zungenriß' and also of the 'Jung-Riß' are not documented clearly (SCHREINER 1989).

The characteristics of the terminal moraine stages of the 'Riß' in the Bavarian Western Salzach glacier lobe (GRIMM et al. 1979) with its inarticulate, external terminal moraine stages, an internal well developed double ridge and a youngest terminal stage, which is not documented directly, are well comparable to the classification of the Rhine-glacier area. Yet in the adjacent Western Inn-glacier area the classification is less comparable (GRIMm et al. in prep.).

For 'Altmoränen' in the remaining Bavaria correspondingly detailed classifications are not available.

\section{Discussion and perspectives}

The status of Quaternary Stratigraphy in the Alpine Foreland of Baden-Wuerttemberg and Bavaria is described by Fiebig et al. (in press), HABbe, Ellwanger \& BeckerHaUmann (2007) or in the stratigraphic chart of the Deutsche Stratigraphische Kommission (2002) and the accompanying comment by LiTT et al. (2005). In addition to the textbooks of JERz (1993), EHLERs (1996), SCHREINER (1997), BENDA (1995) for Southern Germany, vAN HusEN (2000) and Piller et al. (2004) for Austria, Schlüchter \& Kelly (2000) and Preusser (2010) for Switzerland may be consulted for an outline.

The traditional, primarily morphostratigraphical classification used in Bavaria is essentially defined by gravel deposits of different elevations. So far it is suitable especially in the glacial foreland. In contrast the new, substantially lithostratigraphical classification system established in Baden-Württemberg defines units confined by discontinuities (Ellwanger et al. 1995, 2003). This system is based on the analysis of the sequences within the glacial basins of the Rhine glacier. The new classification introduces the so-called 'Hoßkirch-Komplex' (see 3.1.5) for the period of an oldest glaciation and basin formation in the area of Lake Constance preceding the 'Riß' complex. The new concept considers tectonic movements as a reason for all of the 'Deckenschotter' accumulations, not former phases of piedmont glaciations.

Palaeomagnetical investigations in the northern Rhineglacier foreland (Fromm 1994; Ellwanger et al. 1995; Bibus et al. 1996) and in the Bavarian Alpine Foreland (STRATTNER \& Rolf 1995) resulted in a different chronological classification of ('Haslach'-)'Mindel' and 'Günz' and thus also for the related units. Whereas 'Haslach-Mindel' and as a result also 'Günz' in Baden-Wuerttemberg is magnetostratigraphically attributed to the reverse oriented Matuyama, in Bavaria 'Mindel' is completely established in the normal oriented Brunhes epoch. Solely 'Günz' in Bavaria is thought to reach from the Matuyama up to the Brunhes epoch passing the Lower to Middle Pleistocene transition. The reasons for this discrepancy are still open. Probably on both sides of the river Iller (approximately the border between Wuerttemberg and Bavaria) gravel deposits of different ages are assigned to the 'Jüngere Deckenschotter' ('Mindel-Haslach') or 'Tiefere Ältere Deckenschotter' ('Günz'). The gravels of Allschwil with its covering strata containing 5 interglacial soils are classified as 'Jüngere Deckenschotter' (Zollinger 1991). Thus, considerably older deposits may be regarded as 'Mindel' in the upper Rhine area, than in Bavaria where the cover of 'Jüngere Deckenschotter' is less differentiated. But it remains unclear so far where a boundary between the different classification systems can be fixed.

Both classification systems are presented side by side in Table 3. We passed on displaying the classification of the Austrian Quaternary adjacent to the East because it is similar to the Bavarian system. 
An adaptation between the different classification systems seems absolutely essential but against the background of various approaches also complex and interminable. The enforcement of further age-determinations, the enhancement of dating methods and the consolidation of new techniques may display an objective help but will surely implicate the loss of well beloved ideas.

\section{Acknowledgement}

We thank Sabine Schmidbauer from the department 'Cartography' of the Bavarian Environment Agency for the implementation of figures and tables. Johanna Lomax, BOKU Wien, enhanced the first part of our text, not only concerning the English phraseology. Many thanks to her. Furthermore we thank all involved colleagues (especially the patient reviewers) for supporting this compilation with valuable contributions. Sincere thanks to numerous colleagues whose works contributed essential insights to the overall picture, but could not be mentioned here. We apologise for our restriction to recent publications due to some kind of conciseness. Previous papers may be extracted from these publications.

\section{References}

Aguirre, E. \& Pasini, G. (1985): The Pliocene-Pleistocene boundary. - Episodes, 8: 116-120; Beijing.

AD-HOC-AG GeOlogIE: Geologische Kartieranleitung - Fachliche Grundlagen. - http://www.tlug-jena.de/geoka/hauptseite.htm.

Aktas, A. \& Frechen, M. (1991): Mittel- bis jungpleistozäne Sedimente der Hochterrasse in der nördlichen Iller-Lech-Platte. - Geologisches Institut der Universität zu Köln, Sonderveröffentlichungen, 82: 19-41; Köln

BAyerisches Geologisches LANDESAmt [ed.] (1979): Interglaziale und Interstadiale des Pleistozäns im Bayerischen Alpenvorland (Teil I). - Geologica Bavarica, 80: 188 p.; München.

BAyerisches Geologisches LANDEsAmt [ed.] (1983): Interglaziale und Interstadiale des Pleistozäns im Bayerischen Alpenvorland (Teil II). Geologica Bavarica, 84: 213 p.; München.

Becker-Haumann, R. (2005): Anwendung der Geoinformatik für die hochauflösende 3D-Modellierung fluviatiler Terrassenkörper - Die prä-risszeitliche Chronologie und Paläogeographie des Illergletschergebietes, Bayerisches Alpenvorland. - 330 p., Stuttgart (Schweizerbart).

Becker-Haumann, R. \& Frechen, M. (1997): Vergleichende LumineszenzDatierungen mit IRSL und TL am Deckschichtenprofil Bobingen/ Lechtal. - Zeitschrift geologischer Wissenschaften, 25: 617-633; Berlin.

Benda, L. [ed.]: Das Quartär Deutschlands. - 408 p.; Berlin, Stuttgart (Bornträger).

Beug, H.-J. (1976): Die spätglaziale und frühpostglaziale Vegetationsgeschichte im Gebiet des ehemaligen Rosenheimer Sees (Oberbayern). Botanisches Jahrbuch für Systematik, 95 (3): 373-400; Stuttgart.

BEUG, H.-J. (1979): Vegetationsgeschichtlich-pollenanalytische Untersuchungen am Riß/Würm-Interglazial von Eurach am Starnberger See/Obb. - Geologica Bavarica, 80: 91-106; München.

BiBus, E. (1974): Abtragungs- und Bodenbildungsphasen im Rißlöß. - Eiszeitalter u. Gegenwart, 25: 166-182; Öhringen/Württemberg.

Bibus, E. (1995): Äolische Deckschichten, Paläoböden und Mindestalter der Terrassen in der Iller-Lech-Platte. - Geologica Bavarica, 99: 135-164; München (Bayerisches Geologisches Landesamt).

Bibus, E., Bludau, W., Ellwanger, D., Fromm, K., Kösel, M. \& Schreiner, A. (1996): On Pre-Würm glacial and interglacial deposits of the Rhine glacier (South German Alpine Foreland, Upper Swabia, Baden-Württemberg). - In: Turner, C. (ed.): The Early Middle Pleistocene in Europe: 195-204.

Bibus, E. $\mho$ Ellwanger, D. (1995): Gravel pit Bittelschiess. Glacial deposits and fossil soils at the Höchsten. - In: SchIrmer, W. (ed.): Quaternary field trips in Central Europe, 1: 468-470; München (Pfeil).

Bibus, E. ¿ KösEL, M. (1997): Paläoböden und periglaziale Deckschichten im Rheingletschergebiet von Oberschwaben und ihre Bedeutung für Strati- graphie, Reliefentwicklung und Standort. - Tübinger Geowissenschaftliche Arbeiten, D3: 89 p.; Tübingen.

Bibus, E. \& Kösel, M. (2001): Paläoböden von Neufra, Bittelschieß, Baltringen und Rosna. - unpublizierte Manuskripte der Arbeitsgemeinschaft Alpenvorlandquartär (AGAQ): 7 p.; Tübingen.

Bibus, E. \& STRAHL, M. (2000): Zur Gliederung und Altersstellung der bayerischen Hochterrassen nördlich des Donauriedes. - Zeitschrift für Geomorphologie, N. F., 44 (2): 211-232; Berlin, Stuttgart.

BLUDAU, W. (1995): Altpleistozäne Warmzeiten im Alpenvorland und im Oberrheingraben - Ein Beitrag der Palynologie zum 'Uhlenberg-Problem'. - Geologica Bavarica, 99: 119-134; München (Bayerisches Geologisches Landesamt).

BortensChlager, S. (1982): Chronostratigraphic Subdivision of the Holocene in the Alps. - Striae, 16: 75-79; Uppsala.

BRUNNACKER, K. (1953a): Die bodenkundlichen Verhältnisse der würmeiszeitlichen Schotterfluren im Illergebiet. - Geologica Bavarica, 18: 113130, München (Bayerisches Geologisches Landesamt).

BRunNACKer, K. (1953b): Der würmeiszeitliche Löß in Südbayern. - Geologica Bavarica, 19: 58-265; München (Bayerisches Geologisches Landesamt).

BrunNacker, K. (1957): Die Geschichte der Böden im jüngeren Pleistozän in Bayern. - Geologica Bavarica, 34: 1-95; München (Bayerisches Geologisches Landesamt).

BrunNACKer, K. (1959): Zur Kenntnis des Spät- und Postglazials in Bayern. - Geologica Bavarica, 43: 74-150, München.

BrunNACKeR, M. \& BrunNACKer, K. (1962): Weitere Funde pleistozäner Molluskenfaunen bei München. - Eiszeitalter und Gegenwart, 13: 129-137; Öhringen/Württemberg.

BrunNacker, K. (1982): Äolische Deckschichten und deren fossile Böden im Periglazialbereich Bayerns. - Geologisches Jahrbuch, F14: 15-25; Hannover.

Brunnacker, K. , Boenigk, W., Koci, A. \& Tillmanns, W. (1976): Die Brunhes/Matuyama-Grenze am Rhein und an der Donau. - Neues Jahrbuch für Geologie und Paläontologie, Abhandlungen, 151 (3): 358-378, Stuttgart.

BucH, M. W. (1988): Spätpleistozäne und holozäne fluviale Geomorphodynamik im Donautal zwischen Regensburg und Straubing. - Regensburger Geographische Schriften, 21: 197 p.; Regensburg.

Chaline, J. \& Jerz, H. (1984): Arbeitsergebnisse der Subkommission für Europäische Quartärstratigraphie - Stratotypen des Würm-Glazials (Berichte der SEQS 6). - Eiszeitalter und Gegenwart, 34: 185-206; Hannover.

Crowhurst, S. J. (2002): Composite isotope sequence. - The Delphi Project (www.esc.cam.ac.uk/new/v10/research/institutes/godwin/body.html).

DARGA, R. (2009): Auf den Spuren des Inn-Chiemsee-Gletschers - Übersicht. - Wanderungen in die Erdgeschichte, 26: 175 p.; München (Pfeil).

Deнм, R. (1979): Artenliste der altpleistozänen Molluskenfauna vom Uhlenberg bei Dinkelscherben. - Geologica Bavarica, 80: 123-125; München (Bayerisches Geologisches Landesamt).

Deutsche Stratigraphische Kommission [ed.] (2002): Stratigraphische Tabelle von Deutschland 2002. - Potsdam.

Doppler, G. (1980): Das Quartär im Raum Trostberg an der Alz im Vergleich mit dem nordwestlichen Altmoränengebiet des Salzachvorlandgletschers (Südostbayern). - Unpubl. Dissertation Universität München: $198 \mathrm{p}$.

Doppler, G. (1993): Quartär und Molasse in Böschungen der Autobahntrasse A 96 zwischen Ammersee und Mindeltal (Oberbayern, Schwaben). - Geologica Bavarica, 97: 147-154, München.

Doppler, G. (2003a): Zur Gliederung von Ältesten Periglazialschotter und Älteren Deckenschottern im Rot-Günz-Gebiet (Oberschwaben und Bayerisch Schwaben). - Zeitschrift der deutschen geologischen Gesellschaft, 154 (2/3): 255-286; Hannover

Doppler, G. (2003b): Geologische Übersicht des westlichen pleistozänen Salzachvorlandgletschers und seines Vorlands (Oberbayern). - Tübinger Geowissenschaftliche Arbeiten, D 09: 25-46, Tübingen.

Doppler, G., Fiebig, M. \& Meyer, R. K. F. (2002): Geowissenschaftliche Landesaufnahme in der Planungsregion 10 Ingolstadt; Erläuterungen zur Geologischen Karte 1:100 000. - 172 p., München (Bayerisches Geologisches Landesamt).

Doppler, G. \& Jerz, H. (1995): Untersuchungen im Alt- und Ältestpleistozän des bayerischen Alpenvorlands - Geologische Grundlagen und stratigraphische Ergebnisse. Geologica Bavarica, 99: 7-53; München (Bayerisches Geologisches Landesamt).

DrEEsBACH, R. (1986): Zur Lithostratigraphie des Würmglazials im Gebiet des Isar-Loisach-Gletschers / Oberbayern. - Zeitschrift der deutschen geologischen Gesellschaft, 137: 553-572; Hannover. 
Drescher-Schneider, R. (2000a): The Riss-Würm interglacial from West to East in the Alps: an overview of the vegetation succession and climate development. - Geologie en Mijnbouw/Netherlands, Journal of Geosciences, 79: 233-239.

Drescher-Schneider, R. (2000b): Die Vegetations- und Klimaentwicklung im Riss/Würm-Interglazial und im Früh- und Mittelwürm in der Umgebung von Mondsee - Ergebnisse der pollenanalytischen Untersuchungen. - Mitteilungen der Kommission für Quartärforschung der Österreichischen Akademie der Wissenschaften, 12: 39-92; Wien.

Drescher-Schneider, R., Beug, H., Müller, H. \& Knipping, M. (2001): Biostratigraphie. - unpubliziertes Manuskript der Arbeitsgemeinschaft Alpenvorlandquartär (AGAQ): 13 p.

EBEL, R. (1983): Die Lagerungsverhältnisse der Schieferkohlen zwischen der Ostrach und der Iller bei Sonthofen im Oberallgäu. (Mit einem paläontologischen Beitrag von Richard Dehm). - Geologica Bavarica, 84: 123-146; München (Bayerisches Geologisches Landesamt).

EBERL, B. (1930): Die Eiszeitenfolge im nördlichen Alpenvorlande - Ihr Ablauf, ihre Chronologie auf Grund der Aufnahmen des Lech- und Illergletschers. - 427 p.; Augsburg (Benno Filser).

Ebers, E., Weinberger, L. \& Del-Negro, W. (1966): Der pleistozäne Salzachvorlandgletscher. - Veröffentlichungen der Gesellschaft für Bayerische Landeskunde, 19-22: 216 p.; München.

EhLers, J. (1996): Quaternary and Glacial Geology. - 578 p., Chichester (Wiley).

EICHLER, H. ひ SinN, P. (1974): Zur Gliederung der Altmoränen im westlichen Salzachgletschergebiet. - Zeitschrift für Geomorphologie, N.F., 18: 132-158; Stuttgart.

EichleR, H. \& SinN, P. (1975) Zur Definition des Begriffs 'Mindel' im schwäbischen Alpenvorland. - Neues Jahrbuch für Geologie und $\mathrm{Pa}-$ läontologie, Monatshefte, 1975: 705-718; Stuttgart.

EllWANGER, D. (1980): Rückzugsphasen des würmzeitlichen Illergletschers. - Arbeiten aus dem Institut für Geologie und Paläontologie der Universität Stuttgart, N.F., 76: 93-126.

Ellwanger, D., Bibus, E., Bludau, W., Kösel, M. \& Merkt, J. (1995): Baden-Württemberg. - In: BENDA, L. (ed.): Das Quartär Deutschlands: 255-295.

Ellwanger, D., Fejfar, O. \& von Koenigswald, W. (1994): Die biostratigraphische Aussage der Arvicolidenfauna vom Uhlenberg bei Dinkelscherben und ihre morpho- und lithostratigraphischen Konsequenzen. - Münchner Geowissenschaftliche Abhandlungen, A26: 173-191.

Ellwanger, D., Lämmermann-Barthel, J. \& Neeb, I. (2003): Eine 'landschaftsübergreifende Lockergesteinsgliederung' vom Alpenrhein zum Oberrhein. - In: Schirmer, W. (ed.): Landschaftsgeschichte im Europäischen Rheinland. - GeoArchaeoRhein, 4: 81-124; Münster.

Feldmann, L. (1990): Jungquartäre Gletscher- und Flussgeschichte im Bereich der Münchner Schotterebene. - Dissertation Universität Düsseldorf: 355 p.; Düsseldorf.

FeldmanN, L. (1994): Die Terrassen der Isar zwischen München und Freising - Zeitschrift der deutschen Geologischen Gesellschaft, 145: 233-248; Stuttgart.

Feldmann, L. (1998): Der würmzeitliche Isar-Loisachgletscher. - GeoArchaeoRhein, 2: 103-120; Münster.

Fiebig, M., Ellwanger, D. \& Doppler, G. (in press): Pleistocene Glaciations of Southern Germany. - Developments in Quaternary Science, 15 (Elsevier).

Fiebig, M. $\mho$ Preusser, F. (2003): Das Alter fluvialer Ablagerungen aus der Region Ingolstadt (Bayern) und ihre Bedeutung für die Eiszeitenchronologie des Alpenvorlandes. - Zeitschrift für Geomorphologie, N. F., 47 (4): 449-467; Stuttgart.

Fink, J. (1956): Zur Korrelation der Terrassen und Lösse in Österreich. Eiszeitalter und Gegenwart, 7: 49-77; Öhringen/Württemberg.

Firbas, E. (1949): Allgemeine Waldgeschichte. - Spät- und nacheiszeitliche Waldgeschichte Mitteleuropas nördlich der Alpen, 1: 480 p.; Jena (Fischer).

FirBAs, E. (1952): Waldgeschichte der einzelnen Landschaften. - Spät- und nacheiszeitliche Waldgeschichte Mitteleuropas nördlich der Alpen, 2: 256 p.; Jena (Fischer).

FLIRI, F. (1983): Die Inntalterrasse von Gnadenwald und der Bänderton von Baumkirchen. - In: International Union of Quaternary Research - Stratigraphic Commission [ed.]: Führer zu den Exkursionen der Subkommission für Europäische Quartärstratigraphie vom 13. bis 20. September 1983 im Nördlichen Alpenvorland und im Nordalpengebiet (Bayern, Tirol, Salzburger Land, Oberösterreich): 77-81, München.

Frank, H. (1979): Glazial übertiefte Täler im Bereich des Isar-LoisachGletschers. - Eiszeitalter und Gegenwart, 29: 77-99; Hannover.

Frenzel, B. [ed.] (1976): Führer zur Exkursions-Tagung des IGCP-Projek- tes 73/1/24, 1976: 'Quaternary Glaciations in the Northern Hemisphere'. - 141 p.; Stuttgart-Hohenheim.

Frenzel, B. (1978): Das Interglazial vom Pfefferbichl bei Buching, Landkreis Füssen. - Führer zur Exkursionstagung des IGCP-Projektes 73/1/24 (1976): 181-184; Bonn-Bad Godesberg (DFG).

Frenzel, B. (1979): Entwurf einer Beschreibung der Typus-Regionen und Typus-Lokalitäten des Pleistozäns im Alpenvorland, als Diskussionsgrundlage für die Sitzung der Subkommission für Quartärstratigraphie in Hohenheim. - Unpubliziertes Manuskript: 22 p.; Hohenheim.

Frenzel, B. \& Jochimsen, M. (1972): Die Schieferkohlen aus der Umgebung von Wasserburg/Inn. - In: Führer zu den Exkursionen der 16. wissenschaftlichen Tagung der Deutschen Quartärvereinigung: 73-75; Stuttgart-Hohenheim.

German, R. \& Mader, M. (1976): Die Äußere Jungendmoräne bei Waldsee und das Riedtal. - Jahreshefte der Gesellschaft für Naturkunde in Württemberg, 131: 39-49; Stuttgart.

GeYh, M. A. \& MüLlER, H. (2005): Numerical ${ }^{230} \mathrm{Th} / \mathrm{U}$ dating and a palynological review of the Holsteinian/Hoxnian Interglacial. - Quaternary Science Reviews, 24 (16-17): 1861-1872

Geyh, M. A. \& Schreiner, A. (1984): ${ }^{14} \mathrm{C}$-Datierungen an Knochen- und Stoßzahn-Fragmenten aus würmeiszeitlichen Ablagerungen im westlichen Rheingletschergebiet (Baden-Württemberg). - Eiszeitalter und Gegenwart, 34: 155-161; Hannover.

Gibbard, Ph. L., Head, M. J., Walker, M. J. C. \& Subcommission on Quaternary Stratigraphy (2009): Formal ratification of the Quaternary Sys tem/Period and the Pleistocene Series/Epoch with a base at 2.58 Ma. - Journal of Quaternary Science, 25 (2): 96-102.

Grafenstein, U. von, Erlenkeuser, H., Müller, J. \& KleinmannEisenmanN, A. (1992): Oxygen Isotope Records of Benthic Ostracods in Bavarian Lake Sediments. - Naturwissenschaften, 79: 145-152; Ber lin (Springer).

Graul, H. (1949): Zur Gliederung des Altdiluviums zwischen WertachLech und Flossach-Mindel. - Berichte der Naturforschenden Gesellschaft Augsburg, 2: 3-31; Augsburg.

Grimm, W.-D., Bläsig, H., Doppler, G., Fakhrai, M., Goroncek, K., Hintermaier, G., Just, J., Kiechle, W., Lobinger, W. H., Ludewig, H., Muzavor, S., Pakzad, M., Schwarz, U. \& Sidiropoulos, Th. (1979): Quartärgeologische Untersuchungen im Nordwestteil des SalzachVorlandgletschers (Oberbayern). - In: SchlÜchteR, СH. (ed.): Moraines and Varves - Origin, Genesis, Classification: 101-119; Rotterdam (Balkema).

Grimm, W.-D., Wierer, J. F. \& Hintermaier-Erhard, G. (in Vorber.): Erläuterungen zur Geologischen Übersichtskarte des nördlichen InnChiemsee- und des nordwestlichen Salzachgletschergebiets. - Unpubl. Manuskript; München (Bayerisches Landesamt für Umwelt).

Grosse-Beckmann, D. (1993): Die Vegetationsentwicklung Süddeutschlands im Alt- und Mittelpleistozän auf der Grundlage pollenanalytischer Untersuchungen. - unveröff. Staatsexamensarbeit Universität Düsseldorf: 119 p.; Düsseldorf.

GrottenthALER, W. (1980): Erläuterungen zur Geologischen Karte von Bayern 1:25 000, Blatt Nr. 7833 Fürstenfeldbruck. - 82 p.; München (Bayerisches Geologisches Landesamt).

Grottenthaler, W. (2009): Geologische Karte von Bayern 1:25 000; Erläuterungen zum Blatt 8131 Schongau. - 54 p.; Augsburg (Bayerisches Landesamt für Umwelt).

GRÜGER, E. (1979): Die Seeablagerungen vom Samerberg/Obb. und ihre Stellung im Jungpleistozän. - Eiszeitalter und Gegenwart, 29: 23-34; Hannover

GRÜGER, E. (1983): Untersuchungen zur Gliederung und Vegetationsgeschichte des Mittelpleistozäns am Samerberg in Oberbayern. - Geologica Bavarica, 84: 21-40; München (Bayerisches Geologisches Landesamt).

HABBE, K. A. (1986): Bemerkungen zum Altpleistozän des Illergletscher-Gebietes. - Eiszeitalter und Gegenwart, 36: 121-134; Hannover.

HABBE, K. A. (1988): Was kann eine geomorphologische Vollkartierung für die Stratigraphie des Quartärs leisten? - Berliner Geographische Abhandlungen, 47: 177-196; Berlin.

Haвbe, K. A. (1989): Die pleistozänen Vergletscherungen des süddeutschen Alpenvorlandes - ein Resümee. - Mitteilungen der Geographischen Gesellschaft München, 74: 27-51; München.

Habbe, K.-A., Ellwanger, D. \& Becker-HAumann, R. (2007): Stratigraphische Begriffe für das Quartär des süddeutschen Alpenvorlands. Quaternary Science Journal, 56 (1/2): 66-83, Hannover.

Häuselmann, Ph., Fiebig, M., Kubik, P. W. \& Adrian, H. (2007): A first attempt to date the original 'Deckenschotter' of Penck and Brückner with cosmogenic nuclides. - Quaternary International, 164/165: 33-42. 
Hambach, U., Rolf, CH. \& Schnepp, E. (2008): Magnetic dating of Quater nary sediments, volcanites and archaeological materials: an overview. - Eiszeitalter und Gegenwart, 57 (1-2): 25-51; Hannover.

Hilgart, M. (1995): Die geomorphologische Entwicklung des Altmühlund Donautales im Raum Dietfurt-Kelheim-Regensburg im jüngeren Quartär. - Forschungen zur deutschen Landeskunde, 242: 333 p.; Trier.

Hirtlreiter, G. (1992): Spät- und postglaziale Gletscherschwankungen im Wettersteingebirge und seiner Umgebung. - Münchner Geographische Abhandlungen, Reihe B, 15: 154 p.; München.

HöFle, C. ¿ Müller, H. (1983): Interglaziale und interstadiale Stausee ablagerungen bei Steingaden im Ammergebirgsvorland. - Geologica Bavarica, 84: 147-152; München (Bayerisches Geologisches Landesamt).

Ivy-Ochs, S., Schäfer, J., Kubik, P. W., Synal, H.-A. \& Schlüchter, C. (2004): Timing of Deglaciation on the northern alpine Foreland (Switzerland). - Eclogae geologicae Helvetiae, 97: 47-55; Basel.

Ivy-Ochs, S., Kerschner, H., Reuther, A., Preusser, F., Heine, K., Maisch, M., Kubik, P. W. \& Schlüchter, CH. (2008): Chronology of the last glacial cycle in the European Alps. In: Journal of Quaternary Science, 23: 559-573.

JeRZ, H. (1979): Die quartären Ablagerungen im übertieften Wolfratshausener Zungenbecken (Oberbayern). - In: SchlÜchteR, $\mathrm{CH}$. (ed.): Moraines and Varves: 257-260; Rotterdam (Balkema).

Jerz, H. (1982): Paläoböden in Südbayern (Alpenvorland und Alpen). Geologisches Jahrbuch, F14: 27-43; Hannover.

Jerz, H. (1987): Geologische Karte von Bayern 1:25 000, Erläuterungen zum Blatt Nr. 7934 Starnberg Nord. - 128 p., München.

Jerz, H. (1993): Das Eiszeitalter in Bayern - Erdgeschichte, Gesteine, Wasser, Boden. - Geologie von Bayern, 2: 243 p.; Stuttgart (Schweizerbart).

Jerz, H. \& Grottenthaler, W. (1995): Quartärprofile mit Paläoböden in Südbayern. - Geologica Bavarica, 99: 179-185; München.

Jerz, H. \& MANGeLsdorf, J. (1989): Die interglazialen Kalksinterbildungen bei Hurlach nördlich Landsberg am Lech. - Eiszeitalter und Gegenwart, 39: 29-32; Hannover

Jerz, H. \& Schmidt-Kaler, H. (1999): Geologische Karte von Bayern 1:25 000, Erläuterungen zum Blatt Nr. 7234 Ingolstadt. - 86 p., München (Bayerisches Geologisches Landesamt).

Jerz, H., Stephan, W., Streit, R. \& Weinig, H. (1975): Zur Geologie des Iller-Mindel-Gebietes. - 37 p., with Geologische Übersichtskarte 1:100 000; München (Bayerisches Geologisches Landesamt).

Jerz, H. \& Ulrich, R. (1983): Die Schieferkohlevorkommen von Großweil und Schwaiganger. - Geologica Bavarica, 84: 47-68; München (Bayerisches Geologisches Landesamt)

JunG, W. (1979): Die pflanzlichen Großreste des Riß/Würm-Interglazials von Eurach am Starnberger See/Obb. - Geologica Bavarica, 80: 107-113; München (Bayerisches Geologisches Landesamt).

Jung, W., Beug, H.-J. \& Dehm, R. (1972): Das Riß/Würm-Interglazial von Zeifen, Landkreis Laufen a. d. Salzach. - Abhandlungen der Bayerischen Akademie der Wissenschaften, mathematisch-naturwissenschaftliche Klasse, N. F., 151: 131 p.; München.

Keller, O. ¿ Krayss, E. (1998): Datenlage und Modell einer Rhein-LinthVorlandvergletscherung zwischen Eem-Interglazial und Hochwürm. - GeoArchaeoRhein, 2: 121-138; Münster.

Keller, O. \& Krayss, E. (2005): Der Rhein-Linth-Gletscher im letzten Hochglazial. - Vierteljahrsschrift der Naturforschenden Gesellschaft in Zürich, 150 (1-2): 19-32; Zürich.

KLASEN, N. (2008): Lumineszenzdatierung glazifluvialer Sedimente im nördlichen Alpenvorland. - unpubl. Dissertation Universität zu Köln: 209 p.; Köln.

Kleinmann, A. (1995): Seespiegelschwankungen am Ammersee. Ein Beitrag zur spät- und postglazialen Klimageschichte Bayerns. - Geologica Bavarica, 99: 253-367; München (Bayerisches Geologisches Landesamt)

Kleinschnitz, M. \& Kroemer, E. (2003): Geologische Karte von Bayern 1:25 000; Erläuterungen zum Blatt 7233 Neuburg a. d. Donau. - 40 p.; Geologische Karte 1:25 000; München (Bayerisches Geologisches Landesamt).

KoнL, H. (1998): Das Eiszeitalter in Oberösterreich, Teil II - Die eiszeitliche Vergletscherung in Oberösterreich. - Jahrbuch des oberösterreichischen Musealvereins, 143 (1): 175-390; Linz.

Koenne, W. \& Niklas, H. (1916): Erläuterungen zur Geologischen Kar te des Königreichs Bayern 1:25 000, Blatt Nr. 675 Ampfing. - 96 p.; München.

KöNIG, W. (1979): Neuere Forschungsansätze aus dem Gebiet der präwürmzeitlichen Moränen und Schotter des pleistozänen Innvor- landgletschers. - Heidelberger Geographische Arbeiten, 49: 35-46; Heidelberg.

Koenigswald, W. v. (2002): Lebendige Eiszeit - Klima und Tierwelt im Wandel. - 190 p.; Darmstadt (Wissenschaftliche Buchgemeinschaft).

Koenigswald, W. v. \& Heinrich, W.-D. (2007): Biostratigraphische Begriffe aus der Säugetierpaläontologie für das Pliozän und Pleistozän Deutschlands. - Eiszeitalter und Gegenwart, 56 (1/2): 96-115; Hannover.

KovandA, J. (1989): Fossile Mollusken in Kalksinterbildungen (Dauchen) am Lechufer östlich von Hurlach (nördlich Landsberg/Lech). - Eiszeitalter und Gegenwart, 39: 33-41; Hannover.

KovAnDA, J. (2006): 'Fagotia-Faunen' und quadriglazialistisches stratigraphisches System des Pleistozäns im nördlichen Alpenvorland im Vergleich zu einigen klassischen Fundorten im Bereich der nordischen Vereisung Deutschlands. - Journal of Geological Sciences, Anthropozoic, 26: 5-37; Prag (Czech Geological Survey).

Kroemer, E. (2010): Fluviale Geomorphodynamik der Donau im Bereich des Rückstaus durch das Isarmündungsgebiet bei Deggendorf (Niederbayern) und Aussagen zur späthochglazialen und spätglazialen Entwicklung. - Bamberger Geographische Schriften 24: 79-87; Bamberg.

Kroemer, E., Veit, A. \& Neidinger, S. (2007): Geologische Karte von Bayern, Blatt Nr. 7143 Deggendorf. - Augsburg (Bayerisches Landesamt für Umwelt).

Kromer, B. \& Becker, B. (1993): German oak and pine ${ }^{14} \mathrm{C}$ calibration, 7.200 - 9.400 BC. - Radiocarbon, 35: 125-135; Tucson (Arizona).

LEgER, M. (1988): Geomorphologie de la vallee subalpine du Danube entre Sigmaringen et Passau. - These de Doctorat, Université de Paris, VII., 3 Bände: 621 p.; Paris.

LEMPE, B. (2009): Sind die Verwitterungserscheinungen in Schmelzwasserkiesen geeignet zur Stratigraphie? Vorgestellt am Beispiel von Geologischen Orgeln. - unpubl. Vortrag auf Sitzung der Arbeitsgemeinschaft Alpenvorlandquartär (AGAQ); Kaufering.

Link, A. \& Preusser, F. (2005): Hinweise auf eine Vergletscherung des Kemptener Beckens (Südwest-Bayern) im Mittleren Würm. - Eiszeitalter und Gegenwart, 55: 64-87; Hannover.

Litt, Th., Behre, K.-E., Meyer, K.-D., Stephan, H.-J. \& Wansa, St. (2007) Stratigraphische Begriffe für das Quartär des norddeutschen Vereisungsebietes. - Quaternary Science Journal, 56(1-2): 7-65; Hannover.

Litt, Th., Bettis, E. A. III, Bosch, A., Dodonov, A., Gibbard, Ph., Jiaqui, L., Kershaw, P., Koenigswald, W. v., McManus, J., Partridge, T. \& Turner, CH. (in Vorb.): A proposal for the Global Stratotype Section and Point (GSSP) for the Middle/Upper (Late) Pleistocene Subseries boundary. - Unpubl. Manuskript: 36 p.; Bonn.

Litt, Th., Ellwanger, D., Villinger, E. \& Wansa, St. (2005): Das Quartär in der Stratigraphischen Tabelle von Deutschland 2002. - Newsletters on Stratigraphy, 41: 385-399; Stuttgart.

Löscher, M. (1976): Die präwürmeiszeitlichen Schotterablagerungen in der nördlichen Iller-Lech-Platte. - Heidelberger Geographische Arbeiten, 45: IX + 157 p.; Heidelberg.

Löscher, M., Münzing, K. \& Tillmanns, W. (1978): Zur Paläogeographie der nördlichen Iller-Lech-Platte und zur Genese ihrer Schotter im Altpleistozän. - Eiszeitalter und Gegenwart, 28: 68-82; Öhringen/Württemberg.

LožEK, V. (1964): Quartärmollusken der Tschechoslowakei. - Rozpravy Ústředniho ústravu geologického, 31: 374 p.; Prag.

MAISch, M. (1982): Zur Gletscher- und Klimageschichte des alpinen Spätglazials. - Geographica Helvetica, 37 (2): 93-104; Zürich.

Mayr, F. \& Heuberger, H. (1968): Type Areas of Late Glacial and PostGlacial Deposits in Tyrol, Eastern Alps. - University of Colorado Studies, Series in Earth Sciences: Glaciation of the Alps, 7: 143-165; Boulder.

Megies, H. (2006): Kartierung, Datierung und umweltgeschichtliche Bedeutung der jungquartären Flussterrassen am unteren Inn. - Heidelberger Geographische Arbeiten, 120: 206 p.; Heidelberg.

MiaRA, ST. (1996): Deckschichtenuntersuchungen zur Gliederung der Rißeiszeit beiderseits der Iller im Gebiet des Rhein- und Illergletschers (westliches Alpenvorland, Deutschland). - Jahresberichte und Mitteilungen des oberrheinischen geologischen Vereins, N. F., 78: 359-374; Stuttgart.

MüNZING, K. \& OHMERT, W. (1974): Mollusken aus dem älteren Pleistozän Schwabens. - Jahrbuch des Geologischen Landesamts Baden-Württemberg, 16: 61-78.

MüNZING, K. \& AкTAS, A. (1987): Weitere Funde molluskenführender Mergellagen im Unteren Deckschotter von Bayerisch-Schwaben. Jahresberichte und Mitteilungen des oberrheinischen Geologischen Vereins, N. F., 69: 181-193; Stuttgart. 
Murphy, M. A. \& SAlvador, A. (1999): International Stratigraphic Guide - An abridged version. - Episodes, 22: 255-271.

OHMERT, W. (1979): Die Ostracoden der Kernbohrung Eurach 1 (Riß-Eem). - Geologica Bavarica, 80: 127-158; München (Bayerisches Geologisches Landesamt).

OGG, J. G. \& SMITH, A. G. (2004): The geomagnetic polarity time scale. - In Gradstein, F. M., OgG, J. G. \& Smith, A. G. (eds.): Geologic Time Scale 2004: 63-86; Cambridge (University press).

Patzelt, G. (1980): Neue Ergebnisse der Spät- und Postglazialforschung in Tirol. - Jahreshefte der Österreichischen Geographischen Gesellschaft, Zweig Innsbruck, 1976/77: 11-18; Innsbruck.

Patzelt, G. \& Bortenschlager, S. (1978): Zur Chronologie des Spät- und Postglazials im Ötztal und Inntal (Ostalpen, Tirol). - In: FrenzeL, B. [ed.]: Führer zur Exkursionstagung des IGCP-Projekts 73/1/24: 185-197; Stuttgart-Hohenheim.

Patzelt, G. \& Resch, W. (1986): Quartärgeologie des mittleren Tiroler Inntales zwischen Innsbruck und Baumkirchen. - Jahresberichte und Mitteilungen des Oberrheinischen geologischen Vereins, N. F., 68: 43-66; Stuttgart.

Penck, A. (1882): Die Vergletscherung der deutschen Alpen, ihre Ursachen, periodische Wiederkehr und ihr Einfluß auf die Bodengestaltung. - 484 p.; Leipzig (Barth).

Penck, A. (1884): Ueber Periodicität der Thalbildung. - Verhandlungen der Gesellschaft für Erdkunde in Berlin, XI: 39-59; Berlin.

Penck, A. (1899): Die vierte Eiszeit im Bereich der Alpen. Schriften der Vereinigung zur Verbreitung naturwissenschaftlicher Kenntnisse, 39: 1-20.

Penck, A. \& BRÜCKNER, E. (1901-1909): Die Alpen im Eiszeitalter. - 3 Bände: 1199 p.; Leipzig.

Peschke, P. (1976): Pollenanalytische Untersuchungen an Schieferkohlen aus dem Gebiet von Penzberg und Murnau/Obb. - In: Frenzel, B. [ed.]: Führer zur Exkursionstagung des IGCP-Projektes 73/1/24, 1976: 90-106, Stuttgart-Hohenheim.

Peschke, P. (1983a): Palynologische Untersuchungen interstadialer Schieferkohlen aus dem schwäbisch-oberbayerischen Alpenvorland. Geologica Bavarica, 84: 69-99; München (Bayerisches Geologisches Landesamt)

Peschke, P. (1983b): Pollenanalysen der Schieferkohlen von Herrnhausen (Wolfratshausener Becken/Obb.) - ein Beitrag zum Problem interglazialer Ablagerungen in Oberbayern. - Geologica Bavarica, 84: 107121; München (Bayerisches Geologisches Landesamt).

Piller, W. E., Egger, H., Erhart, C. W., Gross, M., Harzhauser, M. Hubmann, B., van Husen, D., Krenmayr, H.-G., Krystyn, L., Lein, R., Lukeneder, A., Mandl, G. W., Rögl, F., Rötzel, R., Rupp, Ch., Schnabel, W., Schönlaub, H. P., Summesberger, H., Wagreich, M. \& Wessely, G. (2004): Die stratigraphische Tabelle von Österreich 2004 (sedimentäre Schichtfolgen). - 1. Aufl.; Wolkersdorf (Österreichische Stratigraphische Kommission).

Preusser, F. (2004): Towards a chronology of the Late Pleistocene in the northern Alpine Foreland. - Boreas, 33: 195-210; Oslo.

Preusser, F. (2010): Stratigraphische Gliederung des Eiszeitalters in der Schweiz (Exkursion D am 8. April 2010). - Jahresberichte und Mitteilungen des oberrheinischen geologischen Vereins, N. F., 92: 83-98; Stuttgart.

Preusser, F., Hajdas, I., Ivy-Ochs, S. [ed.] (2008): Recent progress in Quaternary dating methods. - Quaternary Science Journal (Eiszeitalter und Gegenwart), 57 (1/2): 252 p.; Stuttgart.

ReITNER, J. (2007): Glacial dynamics at the beginning of Termination I in the Eastern Alps and their stratigraphic implications. - Quaternary International, 164/165: 64-84.

RÄHLE, W. (1994): Molluskenfaunen der Kiesgruben Münster S Rain am Lech und Lauter, Bobingen. - unpubl. Bericht; Tübingen.

RÄHLE, W. (1995): Altpleistozäne Molluskenfaunen aus dem Zusamplattenschottern und ihrer Flußmergeldecke vom Uhlenberg und Lauterbrunn (Iller-Lech-Platte, Bayerisch Schwaben). - Geologica Bavarica, 99: 103-118; München (Bayerisches Geologisches Landesamt).

ReIch, H. (1953): Die Vegetationsentwicklung der Interglaziale von Großweil-Ohlstadt und Pfefferbichl im Bayerischen Alpenvorland. - Flora, 140: 386-443; Jena.

Reuther, A. U. (2007): Suface exposure dating of glacial deposits from the last glacial cycle - Evidence from the Eastern Alps, the Bavarian Forest, the Southern Carpathians and the Altai Mountains. - Relief, Boden, Paläoklima: 196 p.; Stuttgart (Schweizerbart).

RöGNER, K. (1979): Die glaziale und fluvioglaziale Dynamik im östlichen Lechgletschervorland - ein Beitrag zur präwürmzeitlichen PleistozänStratigraphie. - Heidelberger Geographische Arbeiten, 49: 67-138; Heidelberg.
RöGNER, K. (1993): Ein fossiler Boden östlich von Mindelheim und seine stratigraphische Bedeutung. - Mitteilungen der Geographischen Gesellschaft München, 78: 5-18; München.

RöGNER, K. (2002): Zum Quartär auf Blatt Markt Rettenbach. - Münchner Geographische Abhandlungen, A52: 17-43; München.

RöGNER, K. (2004): Ein Vorschlag zur Gliederung pleistozäner Ablagerungen im deutschen Alpenvorland basierend auf Ergebnissen aus der südlichen Iller-Lech-Platte. - Mitteilungen der Geographischen Gesellschaft in München, 87: 235-273; München.

RöGNER, K. \& Löscher, M. (1987): Quartäre Sedimentations- und Verwitterungsphasen bei Hinterschmalholz (Regierungsbezirk Schwaben). Mitteilungen der Geographischen Gesellschaft München, 72: 161-170; München.

RöGNER, K. ¿ Löscher, M. (1993): Die fluvial-periglazialen Schotter östlich Memmingen (Bayerisch Schwaben). - Mitteilungen der Geographischen Gesellschaft in München, 78: 85-111; München.

RÖGNER, K., LÖSCHER, M. ஓ ZöLLER, L. (1988): Stratigraphie, Paläogeographie und erste Thermolumineszenzdatierungen in der westlichen Iller-Lech-Platte (Nördliches Alpenvorland). - Zeitschrift für Geomorphologie, N. F., Supplement-Band, 70: 51-73; Stuttgart.

RoppeLt, Tн. (1988): Die Geologie der Umgebung von Obergünzburg im Allgäu mit sedimentpetrographischen Untersuchungen der glazialen Ablagerungen. - unpublizierte Disseration Technische Universität München: 109 S., Geologische Karte 1:25 000; München.

SALVADOR, A. (1994): International Stratigraphic Guide. - Geological Society of America: 214 p.; Boulder.

Schaefer, I. (1953): Die donaueiszeitlichen Ablagerungen an Lech und Wertach. - Geologica Bavarica, 19: 13-64; München (Bayerisches Geologisches Landesamt).

Schaefer, I. (1955): Sur la division du Quaternaire dans l'avant pays des Alpes en Allemagne. - Actes IV. Congress International du Quaternaire (INQUA), Rome/Pise, 1953, vol. 2: 910-914.

SchAEFER, I. (1957): Erläuterungen zur Geologischen Karte von Augsburg und Umgebung 1:50 000, mit einem paläontologischen Beitrag von R. Dehm. - 92 p.; München (Bayerisches Geologisches Landesamt).

SCHAEFER, I. (1975): Die Altmoränen des diluvialen Isar-Loisachgletschers und ihr Verständnis aus der Kenntnis der Paareiszeit. - Mitteilungen der Geographischen Gesellschaft München, 60: 115-153; München.

SCHAEFER, I. (1980): Der angebliche 'altpleistozäne Donaulauf' im schwäbischen Alpenvorland. - Jahresberichte und Mitteilungen des oberrheinischen geologischen Vereins, N. F., 62: 167-198; Stuttgart.

SCHEDLER, J. (1979): Neue pollenanalytische Untersuchungen am Schieferkohlevorkommen des Uhlenberges bei Dinkelscherben (Schwaben). Geologica Bavarica, 80: 165-182; München (Bayerisches Geologisches Landesamt)

SchellmanN, G. (1990): Fluviale Geomorphodynamik im jüngeren Ouartär des unteren Isar- und angrenzenden Donautales. - Düsseldorfer Geographische Schriften, 29: 131 p.; Düsseldorf (Geographisches Institut der Universität)

SchellmanN, G. (2010): Neue Befunde zur Verbreitung, geologischen Lagerung und Altersstellung der würmzeitlichen (NT 1 bis NT3) und holozänen (H1 bis H7) Terrassen im Donautal zwischen Regensburg und Bogen. - Bamberger Geographische Schriften 24: 1-77.

SchellmanN, G., Irmler R. \& SAuer, D. (2010): Zur Verbreitung, geologischen Lagerung und Altersstellung der Donauterrassen auf Blatt L7141 Straubing. - Bamberger Geographische Schriften 24: 79-168.

Scheuenpflug, L. (1971): Ein alteiszeitlicher Donaulauf in der Zusamplatte (Bayerisch Schwaben). - Berichte der Naturforschenden Gesellschaft Augsburg, 27: 3-10; Augsburg.

Scheuenpflug, L. (1979): Der Uhlenberg in der östlichen Iller-Lech-Platte (Bayerisch Schwaben). - Geologica Bavarica, 80: 159-164; München (Bayerisches Geologisches Landesamt).

Schirmer (1983): Die Talentwicklung an Main und Regnitz seit dem Hochwürm. - Geologisches Jahrbuch, A 71: 11-43; Hannover.

Schlüchter, CH. ¿ Kelly, M. A. (2000): Das Eiszeitalter in der Schweiz - Überarbeiteter Neudruck, Stiftung Landschaft und Kies; Uttingen.

SChlüchter, СH. (1989): Thalgut: Ein umfassendes eiszeitstratigraphisches Referenzprofil im nördlichen Alpenvorland. - Eclogae geologicae Helvetiae, 82: 277-284; Basel.

ScHмidT, M. (1911): Rückzugsstadien der Würmvergletscherung im Argengebiet. - Schriften des Vereins für die Geschichte des Bodensees; 40: $1-27$.

SCHNEIDER, M. (1995): Der hochwürmzeitliche Rückzug des Eisrandes im Ammersee-Lobus des Loisach-Gletschers - Zur Frage eines ehemals erhöhten Seespiegels. - Geologica Bavarica, 99: 223-244, München (Bayerisches Geologisches Landesamt). 
SchneIder, Th. (2006): Schwemmkegel-, Talsohlen und Moorentwicklung am Alpennordrand im Spät- und Postglazial. - Geographica Augustana, 1: 338 p.; Augsburg.

Schreiber, U. (1985): Das Lechtal zwischen Schongau und Rain im Hoch-, Spät- und Postglazial. - Geologisches Institut der Universität zu Köln, Sonderveröffentlichungen, 58: 192 p.; Köln.

SchreInER, A. (1989): Zur Stratigraphie der Rißeiszeit im östlichen Rheingletschergebiet (Baden-Württemberg). - Jahreshefte des Geologischen Landesamtes Baden-Württemberg, 31, 183-196.

SchreIner, A. (1996): Die Einführung der Haslacheiszeit und die 3-Teilung der Risseiszeit im östlichen Rheingletschergebiet (SW-Deutschland). - Eclogae geologicae Helvetiae, 89 (3): 991-1005; Basel.

SChreInER, A. (1997): Einführung in die Quartärgeologie. - 2. Aufl.: 257 p.; Stuttgart (Schweizerbart).

SCHREINER, A. \& EBEL, R. (1981): Quartärgeologische Untersuchungen in der Umgebung von Interglazial-Vorkommen im östlichen Rheingletschergebiet (Baden-Württemberg). - Geologisches Jahrbuch, A59: 3-64.

Schröder, J. \& Dehm, R. (1951): Die Molluskenfauna aus der Lehm-Zwischenlage des Deckenschotters von Fischach, Kreis Augsburg. - Geologica Bavarica, 6: 118-120; München (Bayerisches Geologisches Landesamt).

Semmel, A. (1968): Studien über den Verlauf jungpleistozäner Formung in Hessen. - Frankfurter Geographische Hefte, 45: 133 p.; Frankfurt a. M.

SinN, P. (1972): Zur Stratigraphie und Paläogeographie des Präwürm im mittleren und südlichen Illergletscher-Vorland. - Heidelberger Geographische Arbeiten, 37: 159 pp.

Starnberger, R., Terhorst, B., Rähle, W., Peticka, R. \& HaAs, J. N. (2008): Palaeoecology of Quaternary periglacial environments during OIS-2 in the forefields of the Salzach Glacier (Upper Austria). - Quaternary International, 198: 51-61.

Steininger, F. F. \& Piller, W. E. (1999): Empfehlungen (Richtlinien) zur Handhabung der stratigraphischen Nomenklatur. - Courier des Forschungsinstituts Senckenberg, 209: 1-19; Frankfurt.

Strattner, M. \& Rolf, CH. (1995): Magnetostratigraphische Untersuchungen an pleistozänen Deckschicht-Profilen im bayerischen Alpenvorland. - Geologica Bavarica, 99: 55-101; München (Bayerisches Geologisches Landesamt).

Tillmanns, W. (1977): Zur Geschichte von Urmain und Urdonau zwischen Bamberg, Neuburg/Donau und Regensburg. - Sonderveröffentlichungen des Geologischen Instituts der Universität zu Köln, 30: 198 p.; Köln.

Tillmanns, W., Brunnacker, K. \& Löscher, M. (1983): Erläuterungen zur Geologischen Übersichtskarte der Aindlinger Terrassentreppe zwischen Lech und Donau 1:50 000. - Geologica Bavarica, 85: 31 p.; München (Bayerisches Geologisches Landesamt).
Tillmanns, W., Münzing, K., Brunnacker, K. ひ Löscher, M. (1982) Die Rainer Hochterrasse zwischen Lech und Donau. - Jahresberichte und Mitteilungen des oberrheinischen geologischen Vereins, N. F., 64: 79-99, Stuttgart.

Traub, F. \& Jerz, H. (1976): Ein Lößprofil von Duttendorf (Oberösterreich) gegenüber Burghausen an der Salzach. - Zeitschrift für Gletscherkunde und Glazialgeologie, 11: 175-193; Innsbruck.

Troll, C. (1924): Der diluviale Inn-Chiemseegletscher - Das geographische Bild eines typischen Alpenvorlandgletschers. - Forschungen zur deutschen Landes- und Volkskunde, 23: 1-121.

van Husen, D. (2000): Geological Processes during the Quaternary. Mitteilungen der Österreichischen Geologischen Gesellschaft, 92: 135-156; Wien.

VILlinger, E. (2003): Zur Paläogeographie von Alpenrhein und oberer Donau. - Zeitschrift der deutschen Geologischen Gesellschaft, 154 (2-3): 193-253, Stuttgart.

Walker, M., Johnsen, S., Rasmussen, S. O., Popp, T., Steffensen, J.-P., Gibbard, Ph., Hoek, W., Lowe, J., Andrews, J., BJörck, S., Cwynar, L. C., Hughen, K., Kershaw, P., Kromer, B., Litt, Th., Lowe, D. J., Nakagawa, T., Newnham, R. \& Schwander, J. (2008): Formal definition and dating of the GSSP (Global Stratotype Section and Point) for the base of the Holocene using the Greenland NGRIP icecore and selected auxiliary records. - Journal of Quaternary Science, 24 (1) 3-17; (Wiley).

Walker, M., Johnsen, S., Rasmussen, S. O., Steffensen, J.-P., Popp, T., Gibbard, Ph., Hoek, W., Lowe, J., Andrews, J., BJörck, S., Cwynar, L., Hughen, K., Kershaw, P., Kromer, B., Litt, Th., Lowe, D. J., Nakagawa, T., Newnham, R. \& Schwander, J. (2008): The Global Stratotype Section and Point (GSSP) for the base of the Holocene Series/Epoch (Quaternary System/Period) in the NGRIP ice core. - Episodes, 31 (2): 264-267; Beijing.

Wansa, St., Hoselmann, Ch., Katzschmann, L. \& Stephan, H.-J. (2008) Das Quartär im Lithostratigraphischen Lexikon von Deutschland. Abhandlungen der Geologischen Bundesanstalt,Tagungsband DEUQUA 2008: 235-237; Wien.

ZaGwiJn, W. H. (1989): The Netherlands during the Tertiary and the Quaternary; A Case History of Coastal Lowland Evolution. - Geologie en Mijnbow, 68: 116; Dordrecht.

ZAGwiJn, W. H. \& De Jong, J. (1985): Die Interglaziale von Bavel und Leerdam und ihre stratigraphische Stellung im Niederländischen Früh-Pleistozän. - Mededelingen van de Rijks Geologische Dienst, 37(3): 155-169.

Zollinger, G. (1991): Zur Landschaftsgenese und Quartärstratigraphie am südlichen Oberrheingraben - am Beispiel der Lössdeckschichten der Ziegelei Allschwil (Kanton Basel-Landschaft). - Eclogae geologicae Helvetiae, 84 (3): 739-752; Basel. 